PNL-4722

UNI-2522

UC-70A

A Research Report

for UNC Nuclear Industries

\title{
Allowable Residual- \\ Contamination Levels for \\ Decommissioning Facilities \\ in the 100 Areas of the \\ Hanford Site
}

W. E. Kennedy, Jr.

B. A. Napier

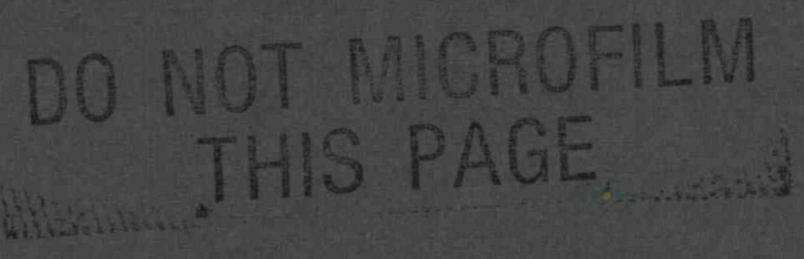

July 1983

Prepared for the U.S. Department of Energy under Contract DE-AC06-76RLO 1830

Pacific Northwest Laboratory

Operated for the U.S. Department of Energy

by Battelle Memorial Institute 

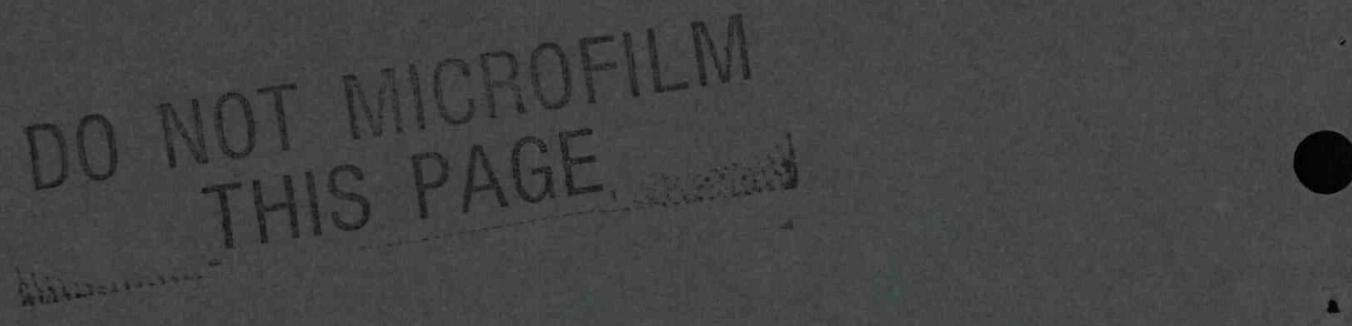

\title{
DISCLAIMFR
}

This report was prepared as an account of work sponsored by an agency of the United States Government. Neither the United States Government nor any agency thereof, nor any of their employees, makes any warranty, express or implied, or assumes any legal liability or responsibility for the accuracy, completeness, or usefulness of any information, apparatus, product, or process disclosed, or represents that its use would not infringe privately owned rights. Reference herein to any specific commercial product, process, or service by trade name, trademark, manufacturer, or otherwise, does not necessarily constitute or imply its endorsement, recommendation, or favoring by the United States Government or any agency thereof. The views and opinions of authors expressed herein do not necessarily state or reflect those of the United States Government or any agency thereof.

\author{
PACIFIC NORTHWEST LABORATORY \\ operated by \\ BATTELLE \\ for the \\ UNITED STATES DEPARTMENT OF ENERGY \\ under Contract DE-AC06-76RLO 1830
}

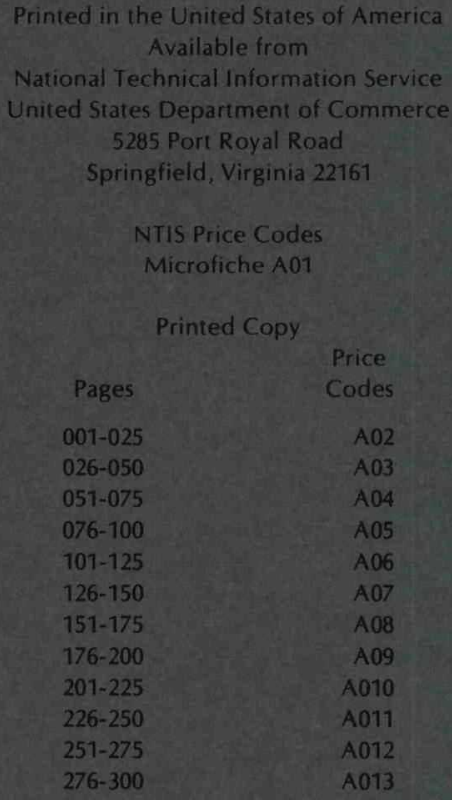




\section{DISCLAIMER}

This report was prepared as an account of work sponsored by an agency of the United States Government. Neither the United States Government nor any agency Thereof, nor any of their employees, makes any warranty, express or implied, or assumes any legal liability or responsibility for the accuracy, completeness, or usefulness of any information, apparatus, product, or process disclosed, or represents that its use would not infringe privately owned rights. Reference herein to any specific commercial product, process, or service by trade name, trademark, manufacturer, or otherwise does not necessarily constitute or imply its endorsement, recommendation, or favoring by the United States Government or any agency thereof. The views and opinions of authors expressed herein do not necessarily state or reflect those of the United States Government or any agency thereof. 


\section{DISCLAIMER}

Portions of this document may be illegible in electronic image products. Images are produced from the best available original document. 
This report was prepared as an account of work sponsored by an agency of the United States

Government. Neither the United States Government nor any agency thereof, nor any of their employees, makes any warranty, express or implied, or assumes any legal liability or responsibility for the accuracy, completeness, or usefulness of any information, apparatus, product, or process disclosed, or represents that its use would not infringe privately owned rights. Reference herein to any specific commercial product, process, or service by trade name, trademark, manufacturer, or otherwise does not necessarily constitute or imply its endorsement, recommendation, or favoring by the United States Government or any agency thereof. The views and opinions of authors expressed herein do not necessarily state or reflect those of the United States Government or any agency thereof.

W. E. Kennedy, Jr.

B. A. Napier

July 1983

Prepared for the

U.S. Department of Energy

under Contract DE-AC06-76RLO 1830

Pacific Northwest Laboratory

Richland, Washington

\section{NOTICE}

PORTIONS OF THIS REPORT ARE ILLEGIBLE. 
$-$

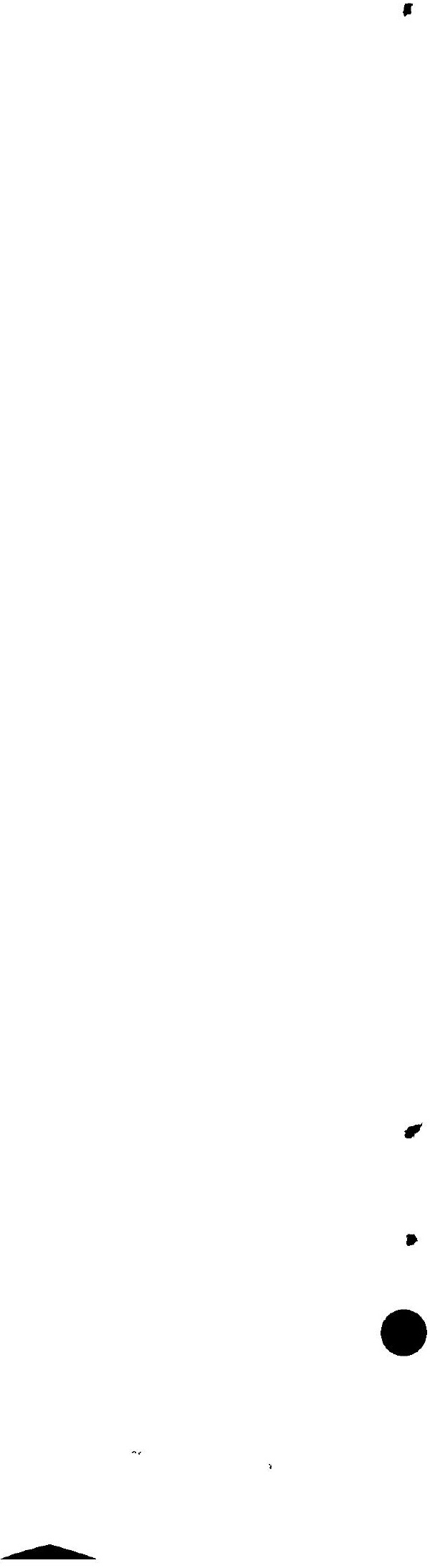

O

3

. 


\section{ABSTRACT}

This report contains the results of a study sponsored by UNC Nuclear Industries to determine Allowable Residual Contamination Levels (ARCL) for five generic categories of facilities in the 100 Areas of the Hanford Site. The purpose of this study is to provide ARCL data useful to UNC engineers in conducting safety and cost comparisons for decommissioning al ternatives. The ARCL results are based on a scenario/exposure-pathway analysis and compliance with an annual dose limit for three specific modes of future use of the 1 and and facilities. These modes of use are restricted, controlled, and unrestricted. The information on ARCL values for restricted and controlled use provided by this report is intended to permit a full consideration of decommissioning alternatives. ARCL results are presented both for surface contamination remaining in facilities (in $\mathrm{dpm} / 100 \mathrm{~cm} 2$ ), and for unconfined surface and confined subsurface soil conditions (in $\mathrm{pCi} / \mathrm{g}$ ). Two confined soil conditions are considered: contamination at depths between 1 and $4 \mathrm{~m}$, and contamination at depths greater than or equal to $5 \mathrm{~m}$. A set of worksheets are presented in an appendix for modifying the ARCL values to accommodate changes in the radionuclide mixture or concentrations, to consider the impacts of radioactive decay, and to predict instrument responses. Finally, a comparison is made between the unrestricted release ARCL values for the 100 Area facilities and existing decommissioning and 1 and disposal regulations. For surface contamination, the comparison shows good agreement. For soil contamination, the comparison shows good agreement if reasonable modification factors are applied to account for the differences in modeling soil contamination and licensed low-level waste. 
SUMMARY

The Allowable Residual Contamination Levels (ARCL) reported in this document for the five categories of facilities in the 100 Areas of the Hanford Site are based on a scenario/exposure-pathway analysis and compliance with an annual dose limit. The five categories of facilities considered are: retention-basin systems, miscellaneous cribs and trenches, sol id-waste burial grounds, nuclear reactors, and fuel-storage basins. Representative radionuclide inventories are developed for each category of facility. These inventories are used in the analyses to determine the potential variability of the ARCL values for various radionuclide mixtures and relative concentrations. Three modes of future use of the facilities and land are considered. They are restricted, controlled, and unrestricted use. Unrestricted use is assumed to occur either immediately or after institutional control periods of 100 or 300 years, representing restricted and controlled use safe-storage options.

A summary of the ARCL results is presented in Table S.1 for surface contamination (in units of $\mathrm{dpm} / 100 \mathrm{~cm}$ ). Only the categories of facilities that contain structures are considered in the surface contamination analysis. These facilities are the retention-basin systems, nuclear reactors, and fuel-storage basins. Restricted-use ARCL values range from $2.4 \times 10^{6}$ to $2.4 \times 10^{7} \mathrm{dpm} / 100 \mathrm{~cm}^{2}$. Controlled-use ARCL values range from $9.2 \times 10^{5}$ to $1.0 \times 10^{7} \mathrm{dpm} / 100 \mathrm{~cm}^{2}$. These ranges reflect the dose potential of the radionuclide inventories for each facility. For unrestricted use, the ARCL values generally increase with time from $T=0$ to $T=300$ years, reflecting the radioactive decay of the more radiotoxic short-lived radionuclides in the mixtures. The ARCL values reported for 100 and 300 years of decay represent the levels that would have to be reached by radioactive decay of the mixtures to assure an unrestricted release.

A summary of the ARCL values for soil contamination is shown in Table S.2. This table contains the ARCL values resulting for the representative radionuclide inventories for all five categories of facilities, for 
TABLE S.1. Summary of the Allowable Residual Contamination Level Values for Surface Contamination in Decommissioned Facilities in the 100 Areas of the Hanford Site

\begin{tabular}{|c|c|c|c|}
\hline Use Mode & $\begin{array}{l}\text { Retention-Basin } \\
\text { System } \\
\left(\mathrm{dpm} / 100 \mathrm{~cm}^{2}\right) \\
\end{array}$ & $\begin{array}{l}\text { Nuclear Reactors } \\
\left(\mathrm{dpm} / 100 \mathrm{~cm}^{2}\right)\end{array}$ & $\begin{array}{c}\text { Fuel-Storage } \\
\text { Basins } \\
\left(\mathrm{dpm} / 100 \mathrm{~cm}^{2}\right)\end{array}$ \\
\hline Restricted Use & $1.1 E+7(a)$ & $2.4 E+7$ & $2.4 E+6$ \\
\hline Control 1ed Use & $4.5 E+6$ & $1.0 E+7$ & $9.2 E+5$ \\
\hline Unrestricted Use(b) & & & \\
\hline - at $T=0$ years & $7.5 E+2$ & $1.6 E+3$ & $1.6 \mathrm{E}+2$ \\
\hline - at $T=100$ years & $1.7 E+4$ & $3.1 E+3$ & $2.2 E+2$ \\
\hline - at $T=300$ years & $2.6 E+4$ & $5.8 E+3$ & $2.2 E+2$ \\
\hline
\end{tabular}

(a) Where $1.1 \mathrm{E}+7=1.1 \times 10^{7}$.

(b) Three decay periods are considered for unrestricted use. They are: $T=0, T=100$, and $T=300$ years.

three decay periods, and for unconfined (surface) soil and confined (subsurface) soil. The ARCL values generally increase wi th time, reflecting the radioactive decay of the more biologically-available radionuclides in the representative mixtures. The ARCL values also increase with depth from surface soils to soils at depths $5 \mathrm{~m}$ from the surface, reflecting the isolation of the contamination from the exposure pathways to man.

A description of how to modify the ARCL values to accommodate changes in the radionuclide mixture or relative concentrations is also given in an appendix. This description includes a worksheet for performing the calculations, including sample problems. Additional worksheets are presented to determine the impacts of radioactive decay on mixtures of radionuclides and to predict instrument responses. 
TABLE S.2. Summary of the Al lowable Residual Contamination Level Values for Decommissioning Facilities in the 100 Areas of the Hanford Site

Facility Category/Soil C

- Unconfined Soil

- Confined Soil (1-4 m deep)

- Confined Soil ( $\geq 5 \mathrm{~m}$ deep)

Miscellaneous Cribs and Trenches

- Unconfined Soil

- Confined Soil (1-4 m deep)

- Confined Soil ( $\geq 5 \mathrm{~m}$ deep)

Solid Waste Burial Grounds

- Unconfined Soil

- Confined Soil (1-4 m deep)

- Confined Soil ( $\geq 5 \mathrm{~m}$ deep)

Nuclear Reactors

- Unconfined Soil

- Confined Soil (1-4 m deep)

- Confined Soil ( $\geq 5 \mathrm{~m}$ deep)

Fuel Storage Basins

- Unconfined Soil

- Confined Soil (1-4 m deep)

- Confined Soil ( $>5 \mathrm{~m}$ deep)
$T=0$ Years $T=100$ Years $T=300$ Years ARCL (pCi/g) ARCL (pCi/g) ARCL (pCi/g)

$\begin{array}{lll}3.4 E+0(b) & 4.4 E+1 & 6.2 E+2 \\ 1.7 E+1 & 6.2 E+2 & 3.2 E+3 \\ 5.3 E+3 & 1.5 E+4 & 6.6 E+4\end{array}$

7. $2 \mathrm{E}-1$

$3.8 \mathrm{E}+0$

$1.0 E+2$

$1.3 E+0$

$5.5 \mathrm{E}+1$

$1.3 E+3$

8.9E-1

4. $5 \mathrm{E}+0$

6. $0 \mathrm{E}+2$

$1.6 \mathrm{E}+0$

$7.9 E+0$

1. $7 \mathrm{E}+2$

$5.6 \mathrm{E}-1$

2. $6 \mathrm{E}+0$

7. $7 \mathrm{E}+1$

9. $9 \mathrm{E}+1$

2. $0 \mathrm{E}+3$

2. $6 \mathrm{E}+0$

3. $2 \mathrm{E}+1$

$9.1 E+2$
$2.4 \mathrm{E}+1$

3. $4 E+2$

7. $1 \mathrm{E}+3$

$6.4 \mathrm{E}+3$

3. $0 E+4$

$6.5 \mathrm{E}+5$

1. $6 \mathrm{E}+3$

$6.8 \mathrm{E}+3$

2. $1 E+5$

2. $7 E+3$

1. $4 \mathrm{E}+4$

2. $7 \mathrm{E}+5$

4. $6 \mathrm{E}+2$

2. $0 \mathrm{E}+3$

5. $3 \mathrm{E}+4$

(a) Three soil conditions are considered: unconfined surface soil (to a depth of $1 \mathrm{~m}$ ), confined soil at depths between 1 and $4 \mathrm{~m}$, and confined soil at depths $>5 \mathrm{~m}$.

(b) Where $3.4 \mathrm{E}+0=\overline{3} .4 \times 10^{0}$. 
Finally, the ARCL results show good agreement with current guidance on decommissioning and 1 and-disposal of radioactive wastes if appropriate modification factors are applied. 
-

-

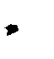

'

-

$\bullet$ 
ABSTRACT $•$ •

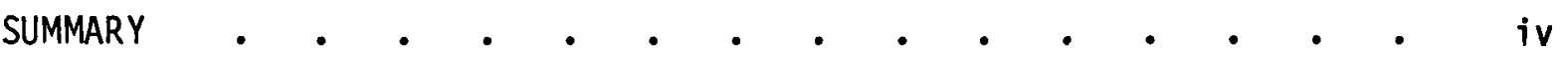
ACKNOWLEDGMENTS $• \cdot$ •

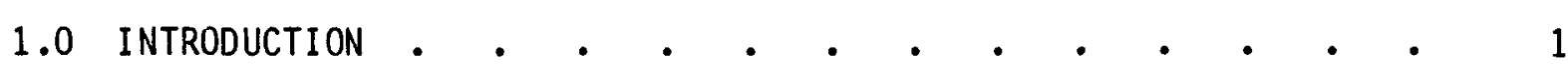

1.1100 AREA FACILITIES AT THE HANFORD SITE $\quad$ • $\quad$ • $\quad$ • $\quad 2$

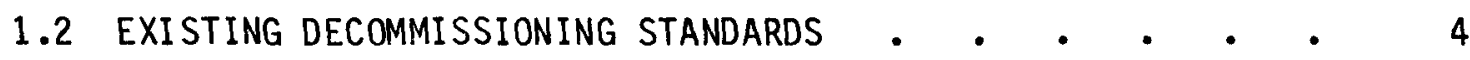

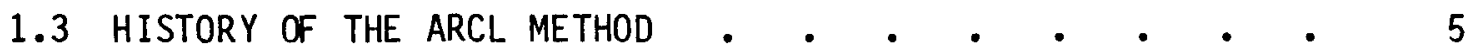

2.0 THE AlLOWABLE RESIDUAL CONTAMINATION LEVEL METHOD $\quad$ • $\quad$ • $\quad 7$

2.1 SUMMARY OF THE METHOD

2.2 ALLOWABLE RESIDUAL CONTAMINATION LEVELS.$\quad \cdot \quad \cdot \quad \cdot \quad \cdot \quad 9$

2.2.1 Maximum Annual Dose . . . . . . . . . 11

2.2.2 Radiation Exposure Pathways and

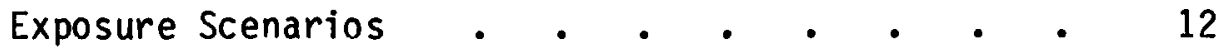

2.3 FUTURE-USE MODES $•$ •

2.3.1 Restricted Use . . . . . . . . . 14

2.3.2 Controlled Use . . . . . . . . . . 14

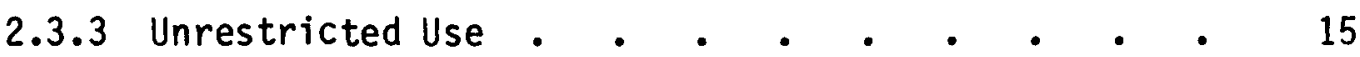

2.4 ALLOWABLE RESIDUAL CONTAMINATION LEVEL

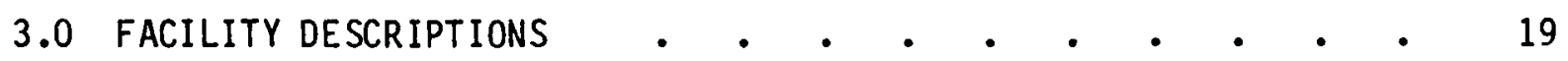

3.1 RETENTION BASIN SYSTEMS $•$ •

3.1.1 Physical Description of the Retention-

Basin Systems . . . . . . . . . 21 
3.1.2 Radiological Characteristics of the Retention-Basin Systems

3.2 Miscellaneous CRibS AND TRENCHES • • • • • • . . 23

3.2.1 Physical Description of the Miscellaneous

Cribs and Trenches . . . . . . . . 25

3.2.2 Radiological Characteristics of the Miscellaneous Cribs and Trenches . . . . . 27

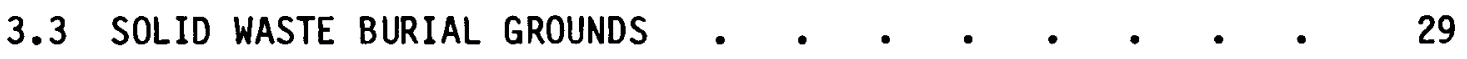

3.3.1 Physical Descriptions of the Solid-Waste
Burial Grounds . . . . . . . 30

3.3.2 Radiological Characteristics of the Solid-Waste Burial Grounds . . . . . . 30

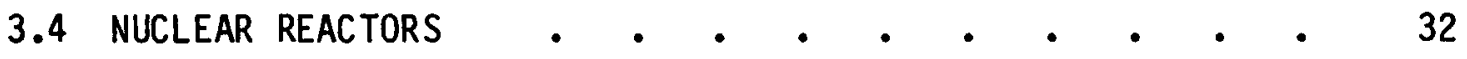

3.4.1 Physical Description of the Nuclear Reactors • • • • • • • • . • • 33

3.4.2 Radiological Characteristics of the
Nuclear Reactors . . . . . . . . . . 33

3.5 FUEL-STORAGE BASINS • • • • • • • • • • • 35

3.5.1 Physical Description of the Fuel-
Storage Basins . . . . . . . . . 36

3.5.2 Radiological Characteristics of the
Fuel-Storage Basins . . . . . . . . . 36

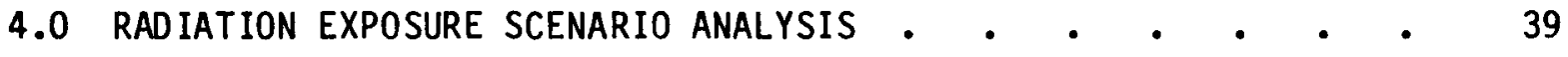

4.1 RESTRICTED USE MODE • • • • • • • • • • • 40

4.2 CONTROLLED USE MODE $•$ •

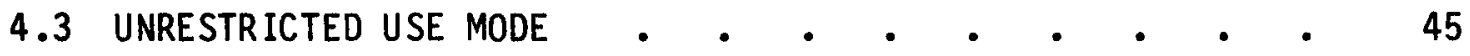

4.3.1 Resource Salvage Exposure Scenario • • • • 45

4.3.2 Resource Recycle Exposure Scenario • • • . 46 
4.3.3 Residential/Home Garden Exposure Scenario _ . $\quad 47$

4.3.4 Residential/Construction Exposure Scenario . . 48

5.0 ALLOWABLE RESIDUAL CONTAMINATION LEVEL CALCULATIONS • • • 51

5.1 DOSE MODELS FOR RADIATION EXPOSURE PATHWAYS • • • • 51

5.2 ALLOWABLE RESIDUAL CONTAMINATION LEVEL MAXIMUM

ORGAN DOSE CONVERSION FACTORS $\quad$ • $\quad$ • $\quad$ • $\quad$ • $\quad$ • 52

5.3 ALLOWABLE RESIDUAL CONTAMINATION LEVEL APPLICATIONS

TO THE 100 AREA FACILITIES • • • • • • • • 56

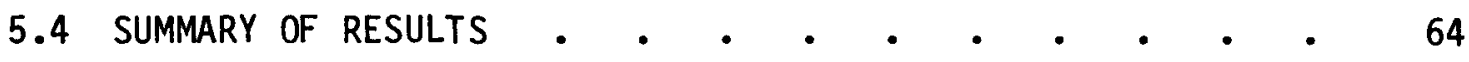

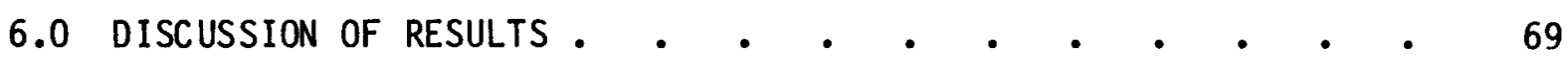

6.1 KEY ASSUMPTIONS $•$ •

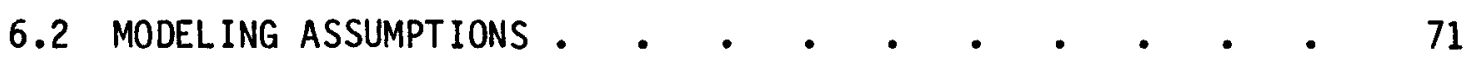

6.3 COMPARISONS WITH EXISTING GUIDANCE - • • • • • $\quad$ - 72

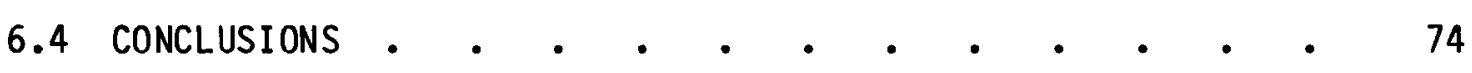

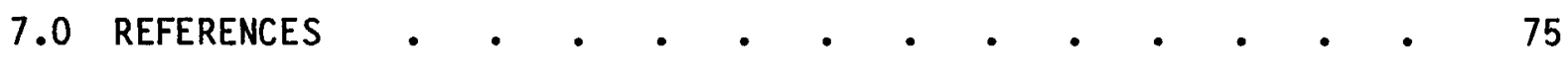

APPENDIX A - SCENARIO-SPECIFIC DOSES AND ALLOWABLE RESIDUAL CONTAMINATION LEVEL VALUES FOR FACILITIES IN THE

100 AREAS OF THE HANFORD SITE • • • • • • • • A.1

APPENDIX B - ALLOWABLE RESIDUAL CONTAMINATION LEVEL WORKSHEETS

FOR FACILITIES IN THE 100 AREAS OF THE HANFORD SITE • B.1

$$
x i / x i \mid
$$




$$
\text { - }
$$

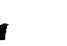


1.1.1 The 100 Areas at the Hanford Site . . . . . . 3

2.1.1 Allowable Residual Contamination Level Method

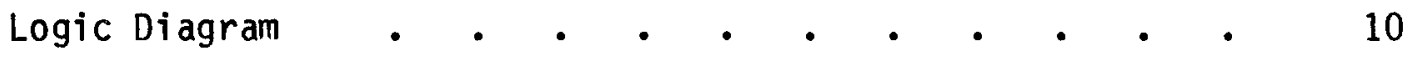

2.4.1 Crop Root Penetration Depths . . . . . . . . 18

3.1.1 Retention Basin System for the D and DR Reactors . . . 20

3.4.1 Typical Reactor Building Layout - 105-K Reactor . . . 34

3.5.1 Typical Fuel-Storage Basins in the 100 Areas . . . . 37

4.1.1 Exposure Scenarios for Decommissioned Facilities in
the 100 Areas of the Hanford Site . . . . . . 41

4.1.2 Dose Rate as a Function of Room Volume for a $60 \mathrm{Co}$

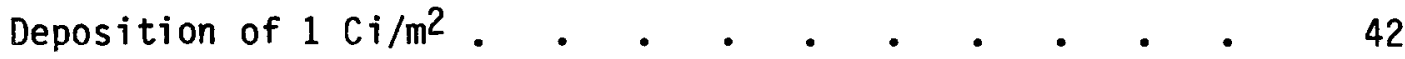

B.1 Allowable Residual Contamination Level Worksheet for Facilities in the 100 Areas of the Hanford Site . . . B.2

B.2 Allowable Residual Contamination Level Worksheet for Facilities in the 100 Areas of the Hanford Site Example Problem 1 • • • • • • • • • • • • B.5

B.3 Allowable Residual Contamination Level Worksheet for Facilities in the 100 Areas of the Hanford Site -

Example Problem 2 • • • • • • • • • • • B.7

B.4 Allowable Residual Contamination Level Decay Correction Worksheet • • • • • • • • • • • • $\quad$ • B.9

B.5 Allowable Residual Contamination Level Radioactive Decay Correction Worksheet - Example Problem 3 . . . . . B.11

B.6 Allowable Residual Contamination Level Worksheet for Facilities at the Hanford Site - Example Problem 3 • . B.12

B.7 Instrument Response Worksheet.$+{ }^{-} \cdot{ }^{-} \cdot{ }^{-} \cdot$ B.13 
B.8 Calibration Curve for the Eberline MS-2 Miniscaler and Beta-Type Scintillation Probe . . . . . . . B.15

B.9 Instrument Response Worksheet - Example Problem 4 - . . B.16

\section{LIST OF TABLES}

S.1 Summary of the Allowable Residual Contamination Level

Values for Surface Contamination in Decommissioned

Facilities in the 100 Areas of the Hanford Site

S.2 Summary of the Allowable Residual Contamination Level Soil

Contamination Values for Decommissioning Facilities in the

100 Areas of the Hanford Site

3.1.1 Representative Radionuclide Inventory for the Retention-

Basin Systems • . • . • . . . • • • .

3.2.1 Miscellaneous Cribs and Trenches in the 100 Areas . . . 28

3.2.2 Representative Radionuclide Inventory for the Miscellaneous Cribs and Trenches

3.3.1 Solid-Waste Burial Ground in the 100 Areas . . . . 31

3.3.2 Representative Radionuclide Inventory for the Solid-Waste Burial Grounds

3.4.1 Representative Radionuclide Inventory for the Nuclear

Reactors . . • • • . • . • . . • .

3.5.1 Representative Radionuclide Inventory for the Fuel-Storage Basins

4.1.1 Referenced Surface Contamination Ingestion Scenarios . .

5.2.1 Allowable Residual Contamination Level Maximum Organ

5.2.2 Scenario-Specific Allowable Residual Contamination Level Dose Factors 
5.3.1 Allowable Residual Contamination Level Values for Decommissioned Facilities in the 100 Areas of the Hanford Site - Restricted Use

5.3.2 Allowable Residual Contamination Level Values for Decommissioned Facilities in the 100 Areas of the Hanford Site - Controlled Use

5.3.3 Allowable Residual Contamination Level Values for Decommissioned Facilities in the 100 Areas of the Hanford Site - Unrestricted Use Surface Contamination at $T=0$ Years $. . . \quad . \quad . \quad . \quad . \quad \cdot$.

5.3.4 Allowable Residual Contamination Level Values for Decommissioned Facilities in the 100 Areas of the Hanford Site - Unrestricted Use Unconfined Surface Soil at $\mathrm{T}=0$ Years. . . . . . . . . .

5.3.5 Allowable Residual Contamination Level Values for Decommissioned Facilities in the 100 Areas of the Hanford Site - Unrestricted Use Confined Soil at Depths Between 1 and $4 \mathrm{~m}$ at $T=0$ Years

5.3.6 Allowable Residual Contamination Level Values for Decommissioned Facilities in the 100 Areas of the Hanford Site - Unrestricted Use Confined Soil at Depths $\geq 5 \mathrm{~m}$ at $T=0$ Years . . . . . . .

5.4.1 Summary of the Allowable Residual Contamination Level Values for Surface Contamination in Decommissioned Facilities in the 100 Areas of the Hanford Site . .

5.4.2 Summary of the Al lowable Residual Contamination Level Soil Contamination Values for Decommissioning Facilities in the 100 Areas of the Hanford Site . . . . .

6.3.1 Comparison of Unrestricted Use Allowable Residual Contamination Level Values with Existing Guidance

A.1 Scenario-Specific Doses - Restricted Use . . . . . A.2

A.2 Scenario-Specific Doses - Controlled Use . . . . . A.3

A.3 Scenario-Specific Doses - Unrestricted Use Surface Contamination at $\mathrm{T}=0$ 
A.4 Scenario-Specific Doses - Unrestricted Use Surface

Contamination at $\mathrm{T}=100$ Years . . . . . . A.5

A.5 Scenario-Specific Doses - Unrestricted Use Surface

Contamination at $T=300$ Years . . . . . . . A.6

A.6 Scenario-Specific Doses - Unrestricted Use Unconfined

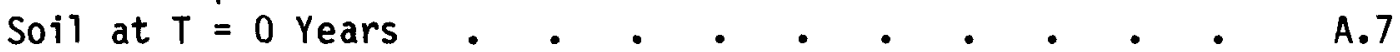

A.7 Scenario-Specific Doses - Unrestricted Use Unconfined

Soil at $T=100$ Years 1. . . . . . . . A.8

A.8 Scenario-Specific Doses - Unrestricted Use Unconfined

Soil at $T=300$ Years $. \quad . \quad . \quad . \quad . \quad . \quad . \quad$. A.9

A.9 Scenario-Specific Doses - Unrestricted Us Confined Soil at

Depths Between 1 and $4 \mathrm{~m}$ at $T=0$ Years . . . . . A.10

A.10 Scenario-Specific Doses - Unrestricted Use Confined Soil

at Depths Between 1 and $4 \mathrm{~m}$ at $\mathrm{T}=100$ Years . . . . A.11

A.11 Scenario-Specific Doses - Unrestricted Use Confined Soil

at Depths Between 1 and $4 \mathrm{~m}$ at $\mathrm{T}=300$ Years . . . . A.12

A.12 Scenario-Specific Doses - Unrestricted Use Confined Soil

at Depths $\geq 5 \mathrm{~m}$ at $\mathrm{T}=0$ Years . . . . . . . . A.13

A.13 Scenario-Specific Doses - Unrestricted Use Confined Soil

at Depths $\geq 5 \mathrm{~m}$ at $\mathrm{T}=100$ Years . . . . . . . A.14

A.14 Scenario-Specific Doses - Unrestricted Use Confined Soil

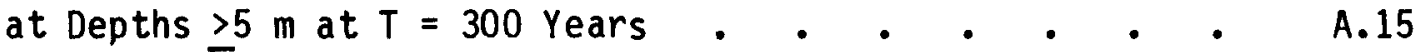

A.15 Allowable Residual Contamination Level Values for

Decommissioned Facilities in the 100 Areas of the

Hanford Site - Unrestricted Use Surface Contamination

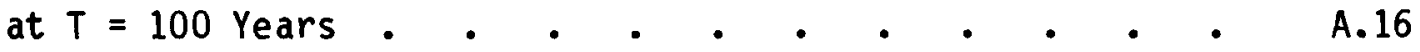

A.16 Allowable Residual Contamination Level Values for Decommissioned Facilities in the 100 Areas of the Hanford Site - Unrestricted Use Surface Contamination

at $\mathrm{T}=300$ Years 
A.17 Allowable Residual Contamination Level Values for Decommissioned Facilities in the 100 Areas of the Hanford Site - Unconfined Surface Soil

at $\mathrm{T}=100$ Years

A.18 Allowable Residual Contamination Level Values for Decommissioned Facilities in the 100 Areas of the Hanford Site - Unconfined Surface Soil

at $T=300$ years

A.19 Allowable Residual Contamination Level Values for Decommissioned Facilities in the 100 Areas of the Hanford Site - Confined Soil at Depths Between 1 and $4 \mathrm{~m}$ at $T=100$ Years

A.20 Allowable Residual Contamination Level Values for Decommissioned Facilities in the 100 Areas of the Hanford Site - Confined Soil at Depths Between

1 and $4 \mathrm{~m}$ at $\mathrm{T}=300$ Years

A.21 Allowable Residual Contamination Level Values for Decommissioned Facilities in the 100 Areas of the Hanford Site - Confined Soil at Depths $>5 \mathrm{~m}$

at $T=100$ Years . . . . . . . . A.22

A.22 Allowable Residual Contamination Level Values for Decommissioned Facilities in the 100 Areas of the Hanford Site - Confined Soil at Depths $>5 \mathrm{~m}$ at $T=300$ Years 
-

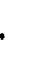

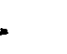

*

$\bullet$ 


\section{ACKNOWLEDGMENTS}

The authors would like to thank all of those individuals who helped make this study possible. In particular, we would like to thank Norma Van Houten for her perseverance and patience in preparing and correcting the manuscript. We would al so like to express special appreciation of the guidance, assistance and encouragement offered by Ed Watson and Joe Soldat in the development of the methods and philosophy applied in this report. 


\subsection{INTRODUCTION}

The U.S. Department of Energy (DOE) is in the process of demonstrating decommissioning technology at the Hanford Site. The project will provide detailed cost, engineering, and safety data useful for determining the final disposition of the remaining Hanford production reactors. A major consideration in developing decommissioning plans is the amount (or level) of radioactive contamination that can be allowed to remain at the site. This report contains a description and the results of a method for determining Allowable Residual Contamination Levels (ARCL) for radionuclides remaining at each of five generic categories of facilities in the 100 Areas at the Hanford Site.

The ARCL results are based on a scenario/exposure-pathway analysis and compliance with an annual dose limit assigned for each of three specific modes of future use of the 1 and and facilities. These modes of use are restricted, controlled, and unrestricted. For restricted and controlled use, institutional controls are assumed to reduce opportunities for exposure by limiting access to the site. This means that some radioactive materials may be left in place to permit radioactive decay. For this study, restricted use is assumed to last for 100 years, and controlled use for 300 years. For unrestricted use, an individual is assumed to have free access to any remaining facilities or radionuclides at the site.

Information on restricted and controlled use is developed to provide engineers with a broad data base. This data base should help permit a full safety and cost consideration of decommissioning al ternatives, including safe-storage options, for the remaining Hanford production reactor facilities.

A brief description of the five generic categories of facilities at the Hanford Site, current regulations regarding residual contamination, and the history of the development of the ARCL method is given in the remainder of this section. A more complete description of the ARCL method is given in Section 2. Facility descriptions for the five generic categories of facilities and a description of the radiation exposure scenarios developed 
for each mode of future use are given in Sections 3 and 4 . A description of the dose-pathway analysis and the ARCL results are given in Section 5 . Finally, the results of the ARCL method are discussed and compared to existing regulations in Section 6 .

\subsection{AREA FACILITIES AT THE HANFORD SITE}

The 100 Areas are located in the northern portion of the Hanford Site along the Columbia River as shown in Figure 1.1.1. The areas shown contain eight graphite-moderated nuclear reactors that used Columbia River water for once-through cooling. The reactors operated from 1944 through the mid1960 's to produce plutonium for the national weapons program. During the years of reactor operation, about 50 radioactive liquid-disposal sites, 23 solid-waste burial grounds, and 35 contaminated facilities were established. In addition, about 20 soil contamination areas resulted from leakage of liquid radioactive wastes.

The contaminated facilities in the 100 Areas have been divided into five categories for this study. These categories are: retention-basin systems, miscellaneous cribs and trenches, solid-waste burial grounds, nuclear reactors, and fuel-storage basins. A sixth category, reactor ancillary facilities, is not included in this study since it was considered in a separate study by Kennedy and Napier (1983).

The retention-basin systems include the basins, liquid-waste trenches, effluent lines, and outfall structures. These systems provided a holdup time for the once-through coolant water to permit it to lose heat and to permit radioactive decay of short-lived radionuclides. The liquid-waste trenches were used to receive effluents containing debris from fuelcladding failures and liquids from some decontamination efforts. Miscellaneous cribs and trenches were al so used for ground disposal of liquid wastes from fuel failures and selected decontamination efforts. The 100Area solid-waste burial grounds were used for burial of solid wastes including contaminated paper, rags, concrete, wood, and activated metals like aluminum, steel, iron, and zircaloy. The retired reactors contain activated thermal and biological shields in addition to the activated 
$\omega$

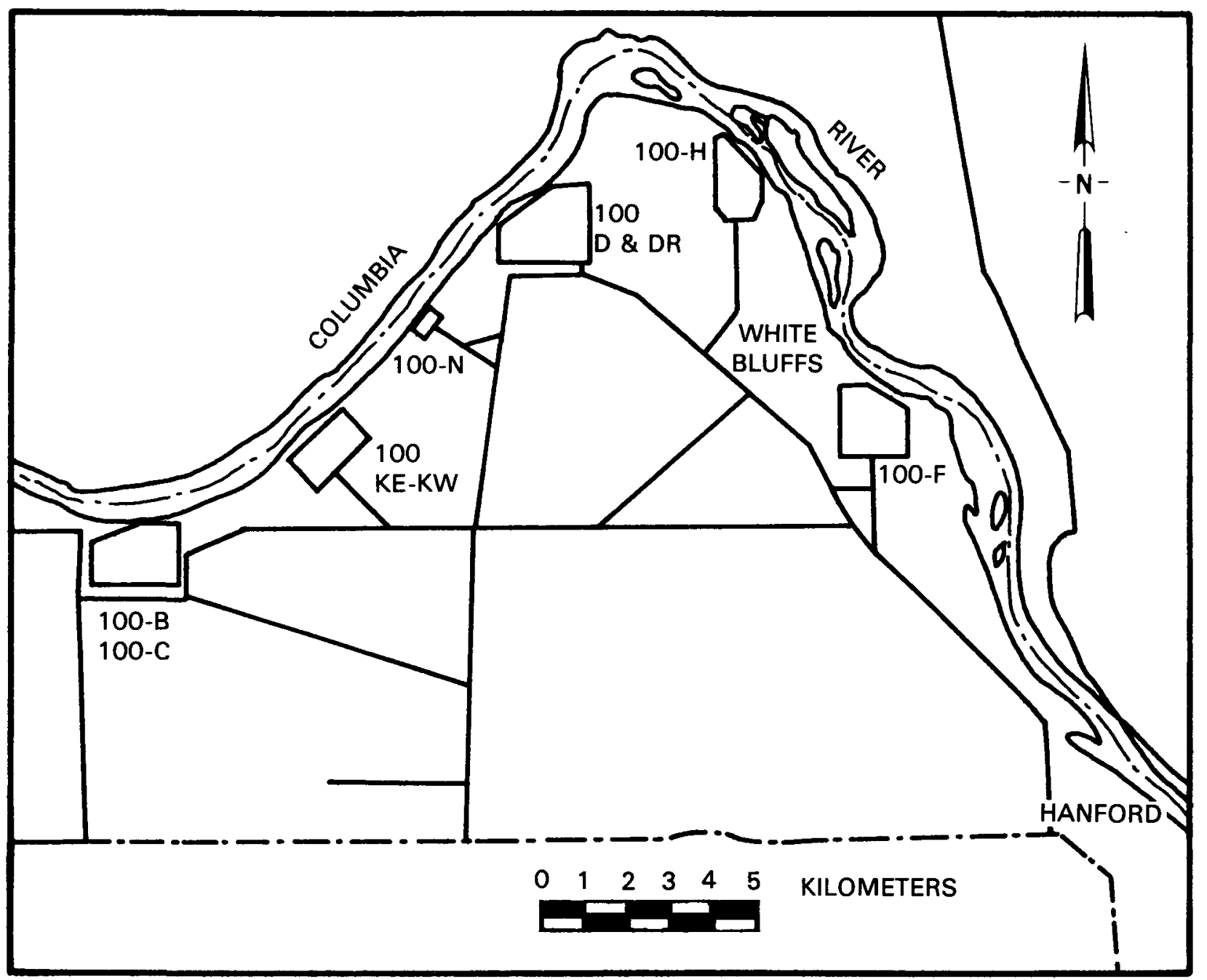

FIGURE 1.1.1. The 100 Areas at the Hanford Site 
graphite cores. And finally, each reactor building contained fuel-storage basins for the irradiated reactor fuel. Further discussions of these five categories of facilities are given in Section 3.0 of this report and in reports by Harmon and King (1975) and Dorian and Richards (1978).

\subsection{EXISTING DECOMMISSIONING STANDARDS}

An examination of existing guidelines and regulations shows that there is a need for a general method of deriving allowable levels of radioactive contamination to permit release of decommissioned nuclear facilities. Currently, there is guidance provided by the U.S. Nuclear Regulatory Commission (NRC) for termination of commercial reactor licenses in Regulatory Guide 1.86 (U.S. AEC 1974), and for release of decontaminated facilities and equipment from by-product, source, or special nuclear material manufacture (U.S. NRC 1976). Other criteria for operation and/or decommissioning of nuclear facilities have been adopted by the NRC (Federal Register 1981), and the U.S. Environmental Protection Agency ( 40 CFR 190; 40 CFR 192; Federal Register 1983). In addition, numerous criteria and standards have been developed for soil contamination. In a recent review of such guidance, Mueller, Kennedy, and Soldat (1981) concluded that it was difficult to compare soil standards since each was intended for a different situation, and since different units or bases were used. Most of the soil contamination information appeared to be consistent with the philosophy of maintaining exposures at levels "as low as reasonably achievable" (ALARA).

In general, it is difficult to compare the decontamination limits given in most of the cited standards because each was intended for a specific situation and mixture of radionuclides, and because different units are used. Some of the limits specify radionuclide concentrations, while others specify an allowable dose or dose rate. Methods have been proposed by Healy (1974; 1979), Pacific Northwest Laboratory (Kennedy et a1. 1979; Napier 1982), and Oak Ridge National Laboratory (Eckerman and

Young 1980) that define techniques for calculating allowable residual contamination levels for any mixture of radionuclides. These methods all 
rely on a scenario/exposure-pathway analysis based on an acceptable annual dose. The ARCL method applied in this report is such a method.

\subsection{HISTORY OF THE ALLOWABLE RESIDUAL CONTAMINATION LEVEL METHOD}

The ARCL method has been under development at Pacific Northwest Laboratory since 1976. Its first application was as part of a conceptual decommissioning study conducted for the NRC (Schneider and Jenkins 1977). The method has continued to evolve as the NRC conceptual decommissioning studies considered a variety of nuclear facilities ranging from fuel fabrication, through reactor operation, to low-level waste disposal and independent spent-fuel storage. Example applications of the ARCL method that directly relate to this study are contained in reports by Smith, Konzek, and Kennedy (1978), Dak et a1. (1980), and Konzek et al. (1982).

In a recent document by Napier (1982), the ARCL method is formally described and the results of example calculations are presented. In addition, Napier (1982) presented a comparison of ARCL results with other recommendations. In a related application, Kennedy et al. (1982) investigated transuranic advanced disposal systems and applied the ARCL method to develop preliminary 239pu waste disposal criteria for the Hanford Site. These criteria related depth of disposal to allowable concentration based on human intrusion scenarios.

The ARCL method described and applied in this report to the five generic categories of facilities in the 100 Areas at Hanford is similar to the methods used by the NRC to develop criteria for shallow-land burial grounds (U.S. NRC 1982). The major differences are that the NRC provided a "generic" classification system for low-level waste disposal and this report attempts to rely on site-specific conditions for facilities and materials not considered to be low-level waste. 
•

. 


\subsection{THE ALLOWABLE RESIDUAL CONTAMINATION LEVEL METHOD}

The objective of the analysis of the Allowable Residual Contamination Levels (ARCL) of radionuclides in soil or facilities is the determination of whether radioactively-contaminated sites require further decontamination or remedial action prior to release. The results of the analysis may also be used to indicate the general magnitude of any remedial actions required prior to the release. The basic approach taken to calculate the ARCL is presented in this section.

The calculation of ARCL values for radionuclides is dependent on the physical characteristics of each individual contaminated site (size, radionuclide inventory, presence of structures), on the radiation dose limit determined to be "acceptable", and on the scenarios of human exposure judged both to be possible and to result in upper bounds of exposure. The physical characteristics can be determined from a comprehensive site description. Dose limits specifically for decommissioning have not yet been set by regulatory agencies. The draft generic environmental impact statement on decommissioning nuclear facilities (U.S. NRC 1981) contains a recommendation that the allowable residual radioactivity level for facility release be based on the dose anticipated to be received by individuals who use that facility. The NRC has further recommended that release levels after decommissioning should be set less than or equal to $10 \mathrm{mrem} / \mathrm{yr}$ to the maximum-exposed individual (Federal Register 1981). As set forth in the Energy Reorganization Act of 1974, the U.S. Environmental Protection Agency (EPA) has responsibility for establishing radiation dose standards for the protection of public health and safety. The EPA has not yet instituted these criteria and is not scheduled to do so until 1984 (U.S. NRC 1981). For this report, three possible modes of future use of the site are considered; restricted, controlled, and unrestricted. For the restricted and controlled modes, an example dose limit of $500 \mathrm{mrem} / \mathrm{yr}$ is used in this report because the sites will still be under government supervision. For unrestricted use, an example dose 1 imit of $10 \mathrm{mrem} / \mathrm{yr}$ is used. These use modes are further described in Section 2.3. For contaminated soil areas, the impact of increased depth of overburden is reflected by applying modification 
factors and special scenario considerations to the calculated ARCL values. Details of the modifications are given in Section 2.4 .

\subsection{SUMMARY OF THE METHOD}

A simplified logic diagram of the ARCL method is shown in Figure 2.1.1. As illustrated, the necessary prerequisite to any analysis is a characterization of the contaminated area, including location, size, radionuclide inventory, depth of overburden (for contaminated soil zones), and descriptions of existing barriers to waste migration and to human intrusion. These details, in conjunction with a description of the proposed release mode, allow preparation of realistic site-specific radiation-exposure scenarios. The heart of the ARCL method is an analysis of the potential maximum annual radiation dose to an exposed individual. If the potential dose to the individual is less than the design-objective dose limit, then no further actions are required for that site. If it is predicted that the potential dose may exceed the design objective, the need for further decontamination or remedial action is indicated.

The general method for calculating the ARCL of radionuclides consists of four steps:

1. From the information presented in the site description, develop a plausible scenario (or set of scenarios) for transfer of contamination to an individual consistent with the proposed future-use mode.

2. From the radionuclide inventory given in the site description, calculate the maximum annual radiation dose for the site and future-use mode exposure scenario.

3. Calculate the ARCL for all nuclides in the mixture, back calculating from the maximum annual dose. This calculation is performed for those times that may maximize the potential exposure.

4. Test whether application of additional engineered barriers or removal of certain areas of contamination will improve the site characteristics. Note: This test is not demonstrated in this report. 
The primary objective of the ARCL is a screening determination of whether or not an individual facility or site requires further decontamination or remedial actions. A secondary objective is to permit a determination of what remedial actions could be effective. The ARCL method does not choose the most appropriate disposal al ternative, nor does it automatically provide the best means of hazard mitigation. Analysis of remedial actions is simply an extended analysis of a site with modified physical characteristics.

The extent of proposed remedial actions will depend on the possible uses of the land or facilities that are projected. For the purposes of this report, three possible modes of future use are considered, each with possible scenarios that prove limiting. These future-use modes are restricted, control led, and unrestricted. For restricted use, governmental control of the site is as sumed to continue for the next 100 years. During the 100-year period, access to the site is limited by fences, markers, and intrusion barriers. The site is routinely patrolled to detect unauthorized intruders. Following the 100-year period, the site is assumed to be cleaned up to the unrestricted-use levels. The second mode is controlled use. Partial institutional controls are assumed to limit human activities at the site for a period of 300 years. Minimal surveillance and maintenance is assumed, and historical records, markers, and zoning restrictions prevent major disruptions of the site. Following the 300year period, the site is assumed to be cleaned to unrestricted-use levels. The unrestricted-use mode, besides following the other two modes, is postulated to begin immediately following decommissioning. No controls remain over use of the site or any remaining contents. Details of these release modes are given in Section 2.3.

\subsection{ALLOWABLE RESIDUAL CONTAMINATION LEVELS}

The design objective is a limit on the maximum annual radiation dose to an individual. The annual dose is a function of the quantity and spectrum of contaminant radionuclides and the exposure pathways to man. The design-objective dose limit is converted to the site-specific, 


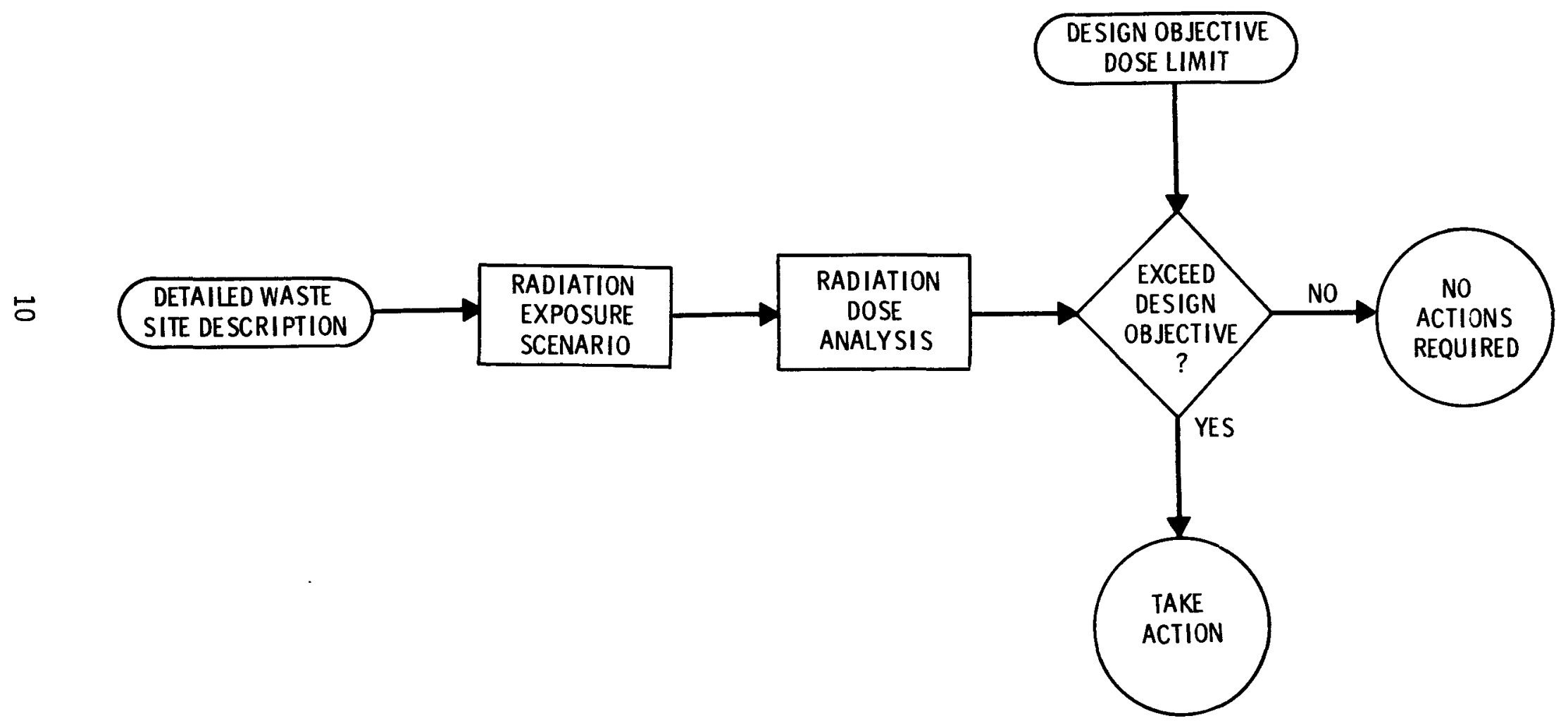

FIGURE 2.1.1. ALLOWABLE RESIDUAL CONTAMINATION LEVEL METHOD LOGIC DIAGRAM 
measurable quantity (the $A R C L$, in $d p m / 100 \mathrm{~cm}^{2}$ for surfaces or $p C i / g r a m$ for soils) through applicable exposure scenarios. Each of these concepts is described in this section.

\subsubsection{Maximum Annual Dose}

There are four basic categories of public radiation doses that could be calculated to measure public exposure. These are:

1. One-year dose from one year of exposure (external plus internal). This is the dose currently used for comparison with occupational exposure standards and the one originally used for comparison with public standards.

2. Committed dose from one-year external exposure plus extended internal dose accumulated as a result of a one-year intake (ingestion plus inhalation). Normally, a 50- or 70-year dose commitment period is used. This dose is the one currently being used by most of those who calculate public doses and is the one used for occupational recordkeeping in 10 CFR Part 20 (1982).

3. Accumulated dose from a lifetime (50 or 70 years) of external exposure plus intake via ingestion and inhalation. This includes the effects of radionuclide accumulation or decay in the environment during the exposure period. This dose can be most closely related to health effects resulting from radiation exposure.

4. Maximum annual dose during a lifetime (50 or 70 years). This dose is calculated for each year of exposure accounting for each year's external exposure plus the internal dose from radionuclides taken in during the year of interest and all previous years. The maximum annual dose is identified by inspection for each organ. This type corresponds most closely to the existing guides for occupational and public exposure which contain standards for annual radiation dose.

The method for determining ARCL used in this report is a comparison of a calculated maximum annual dose received by a maximally-exposed individual with assumed annual dose limits. When internal exposure from inhalation 
and/or ingestion is the dominant dose contributor during continuous exposure, the maximum annual dose may not occur in the first year. Thus, for continuous exposure, a first-year dose may not predict the most restrictive contamination level. Alternative methods might include calculation of the dose commitment from one year of exposure or calculation of the 1 ifetime integrated dose from continuous exposure; however, no recognized standards limiting these types of doses exist. Thus, the maximum annual dose is appropriate for use in determining ARCL.

\subsubsection{Radiation Exposure Pathways and Exposure Scenarios}

The potential routes through which people may be exposed to radionuclides or radiation are called "exposure pathways". The general pathways can be thought of as external exposure, inhalation, and ingestion. Doses from external exposure result from direct radiation from air, water, soil, and contaminated structures. Doses from inhalation can result from breathing aerosols released from facilities or from resuspended materials. Doses from ingestion are water, fish, waterfowl, game, food crops, animal products, or direct consumption of small amounts of material transferred from contaminated surfaces to the hands. The ARCL for individual sites is based on the sum of exposures through all the selected pathways in a radiation exposure scenario analysis.

The key to the ARCL method, as shown in Figure 2.1.1, is an analysis of the maximum annual radiation dose to an individual. This dose is calculated by summing the doses from many exposure pathways. The pathways are chosen depending on the ways an individual could be exposed for each use mode. The collection of appropriate pathways is called an "exposure scenario". The ability of the user of the method to choose the exposure scenario is what gives the ARCL method the flexibility to handle many types of sites, inventories, and locations.

Preliminary investigations have been performed to examine locations where an individual might reside and receive a radiation dose from contaminated sites. In a previous study of conditions at the Hanford Site, individuals were postulated to live downwind and downstream at distances of 
$10 \mathrm{~km}$ (6.2 miles), $1 \mathrm{~km}$ (3280 feet), and onsite (Napier 1982). For all times and for all exposure scenarios, radiation dose rates to the individuals living out of the immediate vicinity of the contaminated areas were found to be orders of magnitude smaller than those received by the onsite individual. Thus, the onsite exposure scenarios were determined to be the most critical. For the three future-use modes examined in this report, the general types of potential exposure scenarios are as follows:

- restricted use

- recreation (if allowed)

- picnicking

- hunting and harvesting

- inadvertent intruder

- deliberate intruder

- controlled use

- inadvertent intruder

- deliberate intruder

- resident (if allowed)

- farmer (if allowed)

- unrestricted use

- transient

- permanent resident

- well drilling, excavation

- contact with soil, inhalation of resuspended material

- drinking of well water

- backyard garden

- inadvertent intruder

- intentional intruder

- resource recovery

- recovered resource use.

The potential for radiation doses to individuals have been examined for each of these general scenarios. The most restrictive are examined in 
detail in this report. A summary of each scenario selected follows. More detail on the required assumptions is given in Section 4.0 .

\subsection{FUTURE-USE MODES}

This section contains a discussion of the future-use modes assumed for the Hanford 100 Areas.

\subsubsection{Restricted Use}

In the first future-use mode, it is assumed that the 100 Areas will remain a valuable resource to $D O E$ for the near future, and that restricted use of the site will continue for the next 100 years. The facilities are assumed to be decontaminated (if necessary) to the allowable residual contamination levels for restricted use and left in a safe-storage condition. Institutional controls are assumed to last for 100 years. During the 100 years of control, access to the site and facilities is assumed to be limited by fences, markers, and intrusion barriers (such as locked doors and sealed access points). Security surveillance is assumed to continue and minor maintenance of fences and intrusion barriers is assumed to be provided if required. After 100 years, the site is considered to be released for unrestricted use. This means that the contamination levels will have to be reduced to the unrestricted-use allowable residual contamination levels, if they have not been reached through radioactive decay.

During restricted use, only an unauthorized intruder-explorer exposure scenario is assumed. The intruder is assumed to enter the facility and explore for a limited time. His exposure pathways are: direct exposure to penetrating radiation, inhalation of resuspended material, and ingestion of removable material transferred to the hands. The allowable residual contamination levels for restricted use are calculated based on an example orqan dose to this intruder of $500 \mathrm{mrem}$.

\subsubsection{Controlled Use}

The second release mode accounts for a long period of controlled use of the site prior to unrestricted release. This case is intended to 
describe a safe-storage condition where partial institutional controls may help limit human activities in the 100 Areas for a period of 300 years. The facilities are assumed to be decontaminated to the allowable controlled-use, residual contamination level and left in a safe-storage condition. Minimal surveillance and maintenance is assumed to occur during this 300-year period. Marker systems, historical records, and zoning restrictions (or other governmental controls) are assumed to partially limit human intrusion. Radioactive materials are assumed to be left in a safe-storage condition of higher integrity than considered for the restricted-use mode.

During controlled use, unauthorized intrusion is assumed to occur through an intruder-discovery scenario. For this scenario, an intruder is as sumed to enter the facility and begin light construction activities. These activities are assumed to cease when the existence of stored radioactive materials is realized or the intruder is discovered by the agency controlling the use of the site. The individual is assumed to be exposed by the same exposure pathways for the restricted use mode, with appropriate modifications to the exposure scenarios. The allowable residual contamination levels far controlled use of the site and facilities are calculated based on an example orqan dose to this intruder of 500 mrem.

\subsubsection{Unrestricted Use}

The last mode considered is designed to account for unrestricted use of the site and facilities. Unrestricted use is assumed to occur as the final outcome of the first two modes considered (i.e. after 100 years of restricted use and after 300 years of controlled use), and immediately for the third mode (as the result of dismantlement). Thus, unrestricted-use allowable residual contamination levels are calculated for the mixture of radionuclides encountered immediately and as modified by radioactive decay for periods of 100 and 300 years.

During unrestricted use of the site and facilities, the maximum individual is assumed to be exposed as a result of four scenarios. These scenarios are designed to consider resource-salvage activities, resource- 
recycle activities, residential/home-garden, and residential/construction activities. The residential/home-garden scenario is designed to be similar to the scenarios considered by the NRC in the Draft Environmental Impact Statement in support of 10 CFR Part 61. The allowable residual contamination levels calculated for unrestricted use are based on an example allowable organ dose of 10 mrem per year to the most restrictive organ.

\subsection{ALLOWABLE RESIDUAL CONTAMINATION LEVEL MODIFICATION FACTORS}

As described in a report by Napier (1982), the ARCL values calculated for surface soil contamination can be modified to account for the depth of burial or other engineered barriers. The ARCL for radionuclides $i$ (shown as $\left.P_{i}\right)$ can be related to the allowable organ dose (DO) by ratio to the total scenario-specific ARCL doses for the mixture, with depth of burial or barrier-modification factors, as:

$$
P_{i}(p C i / g)=\frac{D O(m r e m / y r)}{A R C L_{j}(r e m / y r \text { per pCi/g) }}\left(\Pi_{j} M_{j}\right)
$$

where $\quad$ DO allowable organ dose limit of either $500 \mathrm{mrem} / \mathrm{yr}$ for restricted and controlled use or $10 \mathrm{mrem} / \mathrm{yr}$ for unrestricted use

ARCL - the scenario-specific ARCL dose for each radionuclide, $i$, in the mixture

$M_{j}$ - modification factors to correct for depth of burial, areal extent or presence of barriers.

For this study, only a depth of burial correction is considered. This modification is of the general form:

$$
M_{j}=e^{a d}
$$

where a - a depth correction constant

d - the depth of overburden, $m$. 
For a contaminated soil or buried waste site covered by a layer of clean soil or overburden, the inhalation pathway (from resuspension) is el iminated and the direct irradiation pathway is reduced as a function of the overburden depth. Apart from the actions of humans who may dig into the buried wastes, the dominant pathway becomes consumption of plants whose roots penetrate the overburden. The fraction of the plant roots that penetrate the overburden is a function of the type of plant and the depth that the waste is buried. Estimates of the fraction of plant roots below a given depth have been estimated by Napier (1982) and are shown in Figure 2.4.1. For this analysis, crop uptake of radionuclides is assumed to be directly proportional to the fraction of active roots that penetrate the overburden. Thus, the concentration of radionuclides in farm crops grown over a site is scaled logarithmically with depth as shown in the figure. In addition to root penetration, human construction activities (i.e., basement construction) are al so considered for radionuclides buried in the top $5 \mathrm{~m}$ of soil. A more detailed description of the radiation exposure scenarios considered for buried radioactive materials is given in Section 4.0 . 


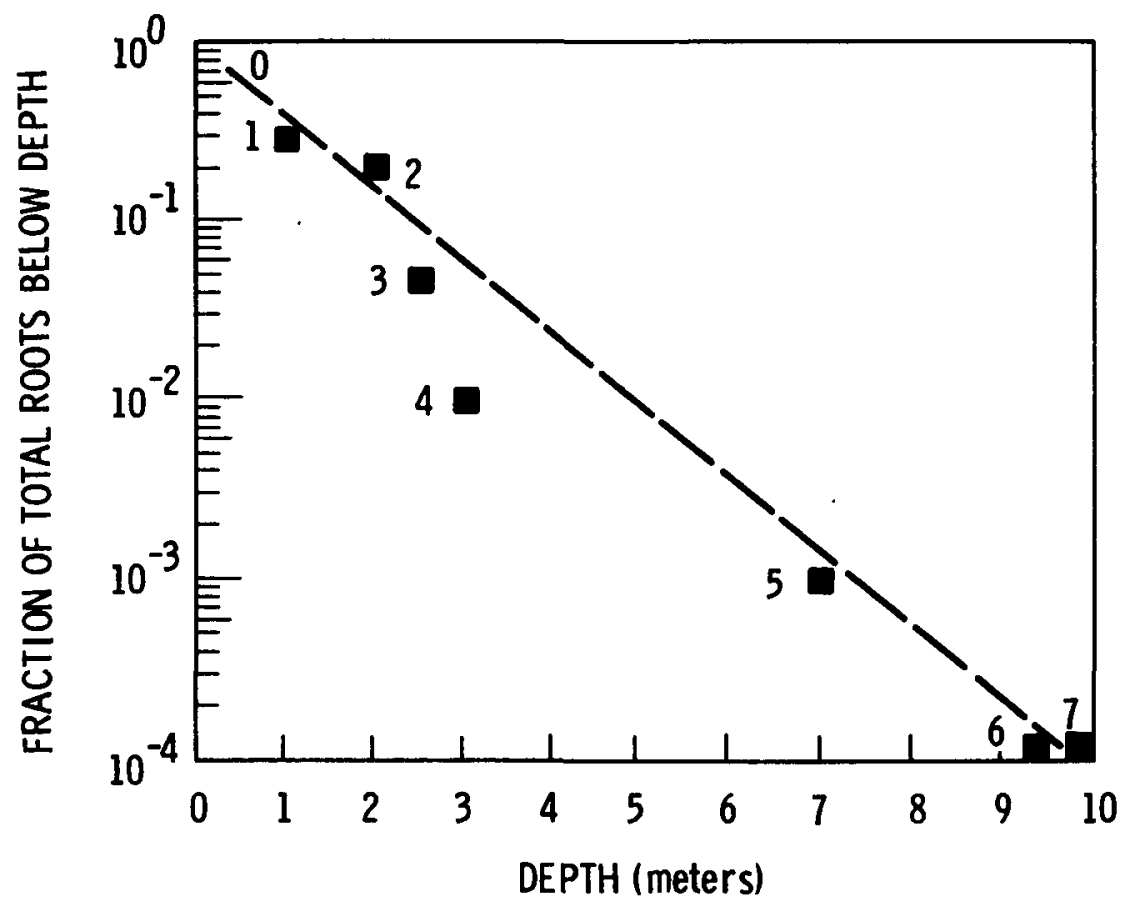

REFERENCES

0. $100 \%$ OF PLANT ROOTS ASSUMED TO BE AT OR BELOW SOIL SURFACE

1. $70 \%$ OF ALFALFA ROOTS ARE IN THE TOP I meter (WSU 1970)

2. $80 \%$ OF TOMATO ROOTS ARE IN THE TOP 2 meters (SUNSET)

3. 95\% OF GRAPE ROOTS ARE IN THE TOP 2.5 meters (SUNSET)

4. EFFECTIVE DEPTH OF MOST GARDEN CROPS (SUNSET) LOWER DEPTH OF SOME GRASS ROOTS (DEPT. AG. 1951)

5. EFFECTIVE DEPTH OF ALFALFA (WSU 1970, DEPT. AG. 1951)

6. LOWER REPORTED DEPTHS FOR TUMBLEWEED AND GREY RABBIT BRUSH

7. ARBITRARY $10 \mathrm{~m}$ LOWER CUTOFF

FIGURE 2.4.1. Crop Root Penetration Depths 


\subsection{FACILITY DESCRIPTIONS}

To complete a "generic" analysis of Allowable Residual Contamination Levels ( $A R C L$ ) for the retired production reactor facilities in the 100 Areas of the Hanford Site, we have developed brief discussions of the physical and radiological characteristics of the facilities. The contaminated facilities considered in this study are divided into five major categories: retention-basin systems, miscellaneous cribs and trenches, solid-waste burial grounds, nuclear reactors, and fuel-storage basins. A separate analysis of ancillary facilities was conducted earlier and the results were documented by Kennedy and Napier (1983). This section contains brief physical descriptions of typical facilities within each category, a brief review of the radiological characterization data available for each category, and representative radionuclide inventories for each category. The representative radionuclide inventories are 1 isted for the time of the survey $(T=0 \mathrm{yr})$, and corrected for radioactive decay for 100 years $(T=100 \mathrm{yr})$ and 300 years $(T=300 \mathrm{yr})$. More detailed information about each category of facility can be found in documents by Harmon and King (1975) and Dorian and Richards (1978).

\subsection{RETENTION BASIN SYSTEMS}

During operation, the Hanford production reactors used cooling water drawn from the Columbia River on a once-through basis after passage through a conventional water-treatment plant to remove silt and river sediments (Harmon and King 1975). Macro and trace constituents in the river water were activated as the water passed through the reactor cores. This coolant water was then returned to the river through a gravity-flow system. A typical design of the retention-basin system, based on the $D$ and DR reactor effluent system, is shown in Figure 3.1.1 (General Electric Co. 1963). The function of the retention-basin system was to hold up the cooling water long enough to permit radioactive decay of many of the short-lived activation products before the water was returned to the river. Some of the radioactive material in the water was deposited as sludge in the retention basin and effluent lines (Dorian and Richards 1978). The retention-basin systems 


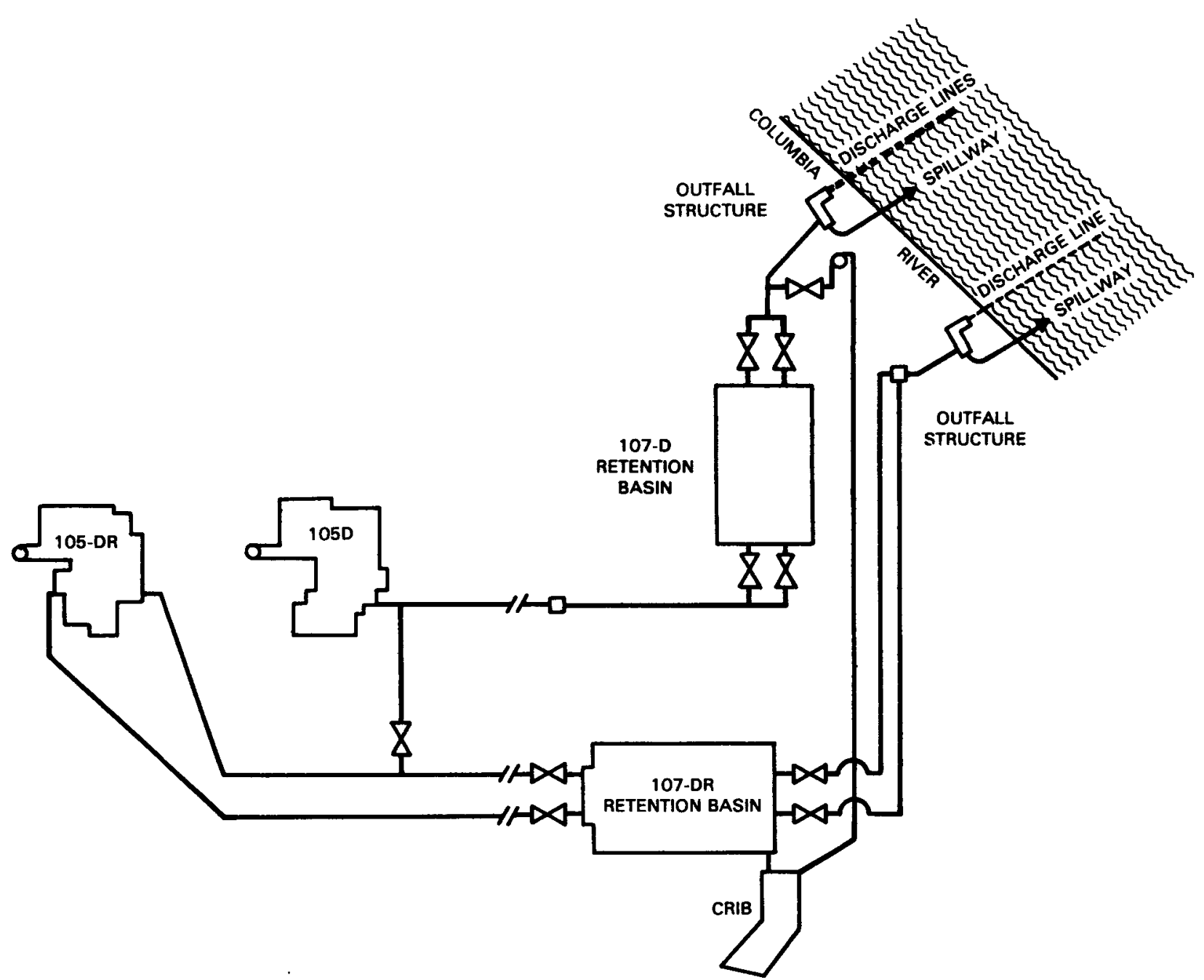

FIGURE 3.1.1. Retention Basin System for the D and DR Reactors 
are assumed to include the 107 liquid-waste trenches, effluent lines, outfall structures, as well as the 107 basins themselves. The following sections contain brief physical and radiological characterizations for retention-basin systems in the 100 Areas at the Hanford Site.

\subsubsection{Physical Description of the Retention-Basin Systems}

The major components of the retention-basin systems are:

1. Effluent Water Lines. These 1 ines run from the reactor buildings to the retention basins, from the retention basins to the outfall structures, and from the outfall structures to the middle of the columbia River, as shown in Figure 3.1.1 (Harmon and King 1975). These lines are generally large diameter $(1$ to $1.5 \mathrm{~m})$ carbon steel pipes; however, reinforced-concrete pipe was used for some of the lines. These lines al so include inspection manholes, junction boxes, tie-lines between parallel legs, and valves for routing the cooling water effluents. The water 1 ines range from about $1.6 \mathrm{~km}$ to $5.6 \mathrm{~km}$ ( 1 to 3.5 miles) per reactor site. These lines were generally placed underground to provide shielding from short-lived gamma radiation (Harmon and $\mathrm{King}$ 1975).

2. 107 Retention Basins. The retention basins are located between the reactors and the river as shown in Figure 3.1.1. The coolant water was held up in the retention basins long enough to permit radioactive decay of short-lived activation products. Two types of retention basins were used: rectangular, concrete reservoirs with pool depths of about $4.5 \mathrm{~m}(15 \mathrm{ft})$ and surface areas ranging from about $10,000 \mathrm{~m}^{2}$ to $17,000 \mathrm{~m}^{2}$ (about $110,000 \mathrm{ft}^{2}$ to $180,000 \mathrm{ft}^{2}$ ); and open-topped, cylindrical, carbon-steel tanks about $5 \mathrm{~m}(16 \mathrm{ft})$ in depth and $76 \mathrm{~m}$ $(250 \mathrm{ft})$ or $100 \mathrm{~m}(330 \mathrm{ft})$ in diameter (Harmon and King 1975). Most of the basins had diverters or baffles to control the path of the water flow.

3. Outfall Structure, Discharge Lines, and Spillways. The outfall structures are open, reinforced-concrete boxes that directed the outfall water through discharge lines. Effluent water was sent through 
discharge lines to the center of the river, except during times of high river levels when the discharge was sent through the spillway (Harmon and King 1975). The outfall structures range in area from about 23 to $110 \mathrm{~m}^{2}$ (250 to $\left.1200 \mathrm{ft}^{2}\right)$. A typical layout of the outfall structures, discharge lines, and spillways is shown in Figure 3.1.1.

4. Sludge-Disposal Trenches and 107 Liquid-Waste Trenches. Sludgedisposal trenches were dug near the 107 retention basins for disposal of the sludge accumulated in the bottom of the basins (Harmon and King 1975). The 107 liquid-waste trenches were used for diverted coolant containing debris from fuel-cladding failures, and for decontamination water generated during deactivation of the basins.

In addition to these contaminated structures, some radioactive contamination was deposited in the soil around leaks in the retention basins and effluent line. After deactivation of the reactors, the retention basins were partially filled with soil to stabilize any remaining contamination in place (Dorian and Richards 1978).

\subsubsection{Radiological Characteristics of the Retention-Basin Systems}

The retention-basin systems handled activation products in trace constituents from the river water, debris from fuel-cladding failures, and decontamination wastes generated during and after reactor operations. The total radionuclide inventories in the retention-basin systems ranged from about 5 to over 400 curies. The general conclusions of the radionuclide characterization program for the retention-basin systems reported by Dorian and Richards (1978) are:

- the average beta-gamma and $239 / 240 \mathrm{pu}$ inventories, remaining with in the retention basis (including concrete), are about equal to the inventories in the surrounding soil resulting from leakage

- principal radionuclides in the inventory include $60 \mathrm{Co}, 63 \mathrm{Ni}, 90 \mathrm{Sr}$, ${ }^{137} \mathrm{Cs}, 152 \mathrm{Eu}$, and ${ }^{154} \mathrm{Eu}$

- average beta-gamma concentrations of the soil-fill covering the sludge range from 101 to $102 \mathrm{pCi} / \mathrm{g}$ 
- average plutonium concentrations of the soil-fill covering the sludge are less than about $10^{-1} \mathrm{pCi} / \mathrm{g}$

- average beta-gamma concentrations of the basin sludge range from $10^{3}$ to $10^{4} \mathrm{pCi} / \mathrm{g}$

- average plutonium concentrations of the sludge range from 101 to $102 \mathrm{pCi} / \mathrm{g}$

- average beta-gamma and plutonium concentrations in the sludge are $10^{1}$ to $10^{2}$ times the average concentrations in the contaminated soil columns from past basin leakage

- line-scale samples have direct GM readings of about 50,000 cpm, with $239 / 240 \mathrm{pu}$ and beta-gamma concentrations ranging from 10 to $300 \mathrm{pCi} / \mathrm{g}$ and 103 to $105 \mathrm{pCi} / \mathrm{g}$, respectively

- the highest $239 / 240 \mathrm{Pu}$ concentration detected is a diversion-box mud sample containing $2.8 \times 10^{3} \mathrm{pCi} / \mathrm{g}$

- the 107 liquid-waste trench inventories range from 15 to $79 \mathrm{Ci}$, with a maximum inventory reported at the $116-\mathrm{K}-2$ trench of about $2100 \mathrm{Ci}$.

A representative radionuclide inventory for the retention-basin systems is given in Table 3.1.1. The radionuclides and concentrations shown in this table were based on the retention-basin system monitoring data reportedı by Dorian and Richards (1978) normalized to $1 \mathrm{pCi} / \mathrm{g}$.

\subsection{MISCELLANEOUS CRIBS AND TRENCHES}

This category includes all of the 100 Area cribs, trenches and French drains apart from the 107 retention-basin diversion trenches. These facilities were usually located within a few hundred feet of the reactor buildings, and were used for ground disposal of liquid wastes. The liquid wastes resulted from fuel failures, decontamination, and liquid and sludge from spent-fuel storage basins (Dorian and Richards 1978). 
Table 3.1.1. Representative Radionuclide Inventory for the Retention-Basin Systems

\begin{tabular}{|c|c|c|c|}
\hline Radionuclide (a) & $\begin{array}{l}\text { Relative Activity } \\
\text { at } \mathrm{T}=0 \mathrm{yr} \\
\left(\mathrm{Ci} / \mathrm{m}^{2} \text { or } \mathrm{pCi} / \mathrm{g}\right)\end{array}$ & $\begin{array}{l}\text { Relative Activity } \\
\text { Decayed to } \\
T=100 \mathrm{yr} \\
\left(\mathrm{Ci} / \mathrm{m}^{2} \text { or } \mathrm{pCi} / \mathrm{g}\right) \\
\end{array}$ & $\begin{array}{c}\text { Relative Activity } \\
\text { Decayed to } \\
T=300 \mathrm{yr} \\
\left(\mathrm{Ci} / \mathrm{m}^{2} \text { or } \mathrm{pCi} / \mathrm{g}\right)\end{array}$ \\
\hline $3 \mathrm{H}$ & $4.8 \mathrm{E}-4$ (b) & $2.0 E-6$ & $3.5 \mathrm{E}-11$ \\
\hline${ }^{14} \mathrm{C}$ & $1.5 \mathrm{E}-3$ & $1.5 \mathrm{E}-3$ & $1.4 \mathrm{E}-3$ \\
\hline${ }^{60} \mathrm{Co}$ & 2.0E-1 & $3.9 E-7$ & $1.5 \mathrm{E}-18$ \\
\hline $6{ }^{3} \mathrm{Ni}$ & $2.4 \mathrm{E}-1$ & 1. $2 \mathrm{E}-1$ & $3.0 \mathrm{E}-2$ \\
\hline${ }^{90} S r+D(C)$ & $5.2 E-4$ & $4.2 \mathrm{E}-5$ & $2.7 E-7$ \\
\hline $137 C s+D$ & $6.8 E-3$ & $6.8 \mathrm{E}-4$ & $6.8 \mathrm{E}-6$ \\
\hline${ }^{152} \mathrm{Eu}$ & $3.6 \mathrm{E}-1$ & $2.2 E-3$ & $7.8 \mathrm{E}-8$ \\
\hline $154 \mathrm{Eu}$ & $1.6 \mathrm{E}-1$ & $5.2 \mathrm{E}-5$ & $5.4 \mathrm{E}-12$ \\
\hline $238 U+D$ & $5.2 \mathrm{E}-6$ & $5.2 \mathrm{E}-6$ & $5.2 \mathrm{E}-6$ \\
\hline${ }^{238} \mathrm{Pu}$ & $4.9 \mathrm{E}-5$ & $2.2 \mathrm{E}-5$ & $4.4 \mathrm{E}-6$ \\
\hline $239 \mathrm{Pu}$ & $1.1 \mathrm{E}-4$ & $1.1 \mathrm{E}-4$ & $1.1 \mathrm{E}-4$ \\
\hline Totals & 1.0 & 0.12 & 0.032 \\
\hline
\end{tabular}

(a) Based on information for Dorian and Richards (1978).

(b) Where $4.8 \mathrm{E}-4=4.8 \times 10^{-4}$.

(c) $+D$ means plus short-lived daughter products.

Cribs were usually large, rock-filled, wooden boxes located far enough below grade ( 3 to 9 meters) to reduce surface dose rates. These wooden boxes were usually open on the top and bottom, and often were attached to a clay pipe tile-field for distribution of the liquid wastes. Cribs were used to dispose of intermediate-level effluents containing radioactivity levels ranging from $10^{-5}$ to $100 \mu \mathrm{Ci} / \mathrm{ml}$. These cribs covered areas ranging from $9 \mathrm{~m}^{2}$ to $20 \mathrm{~m}^{2}$. Other cribs were constructed by partly filling an excavation with sorted rock or gravel, topped by an impermeable membrane or layer of asphalt. These cribs were covered by a layer of soil to reduce surface dose rates, and covered areas ranging from $9 \mathrm{~m}^{2}$ to $2600 \mathrm{~m}^{2}$. French drains are essentially the same as cribs, except that they are much 
smaller, and were used for small-volume waste streams (Harmon and King 1975).

Trenches were long, unlined excavations used for disposal of low- and intermediate-level liquid wastes. Trenches in the 100 Areas were used to receive reactor coolant water containing fuel-rupture debris and decontamination liquids (Harmon and King 1975).

Brief descriptions of the physical and radiological characteristics of the cribs and trenches included in this category are given in the following sections.

\subsubsection{Physical Description of the Miscellaneous Cribs and Trenches}

The major cribs and trenches in the 100 Areas are generally separated into the following:

1. Storage-Basin Trenches. Storage-basin trenches for five of the reactor buildings were dug between 1946 and 1955. These trenches were

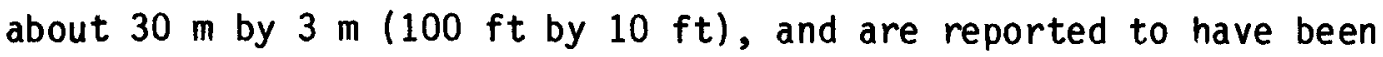
covered by 2 to $3 \mathrm{~m}$ of soil. During their operation, these trenches received sludge and water from the 105 metal storage buildings (Dorian and Richards 1978).

2. 105 Pluto Cribs. Six of the 100 Area reactors had pluto cribs, and they all were dug between 1950 and 1952. These were all small cribs of about $3 \mathrm{~m}$ by $3 \mathrm{~m}$ by $3 \mathrm{~m}$ ( $10 \mathrm{ft}$ by $10 \mathrm{ft}$ by $10 \mathrm{ft}$ ) designed to receive water from individual process tubes after fuel cladding failures. Most of these cribs were used for less than two years and are reported to be covered by 2 to $3 \mathrm{~m}$ of soil. The last pluto crib dug was the 116-c-2 crib. It was larger than the other cribs, and of a different design. It operated until 1969. This crib received decontamination wastes in addition to the process tube wastes. Unlike the other pluto cribs, this crib had a sand filter (french drain) as a first stage prior to discharge of the effluent to the soil column of the crib (Dorian and Richards 1978). 
3. 105 Dummy/Perf Decontamination Cribs. Three 105 dummy decontamination cribs were dug in the 1950's to receive liquid wastes from decontamination of the fuel element spacers (process dummies). These cribs were in operation until the mid to late 1960's (Dorian and Richards 1978).

4. 1608 Liquid-Waste Trenches. Two 1608 liquid-waste trenches were dug (for the $F$ and $H$ reactors) in 1952 and 1953 to receive liquid effluents from the Ball 3X Project. Waste water from the 105 buildings was pumped by the 1608 pumphouse to the trench located outside of the exclusion area fence. These trenches were in operation until 1965. The contaminated soil areas associated with operations of the two 1608 liquid- waste trenches are reported to have been covered by $6 \mathrm{~m}$ and $2 \mathrm{~m}$ of soil (Dorian and Richards 1978).

5. 117 Cribs. Four 117 cribs were constructed at four reactor sites in 1960. They were designed to receive liquid drainage from the confinement system 117 building seal-pits. Only short half-life liquids were released to these cribs, and they were generally released from radiological controls prior to 1967 (Dorian and Richards 1978).

6. 115 Cribs. Two 115 cribs were constructed in 1955 to receive liquid wastes from the reactor-gas purification systems at the KE and KW reactors. These cribs were of underground French-drain construction and operated until the early 1970's (Dorian and Richards 1978).

7. 108 Cribs. Contaminated liquid effluents from the 108 buildings were sent to underground French drains. The three 108 cribs were constructed in the early to mid 1950 's and operated until the mid to late 1960 's.

8. 0ther Cribs and Trenches. The Lewi s Canal, 100-F ball-washer crib, and 1706-KER crib are included as other cribs and trenches. The Lewis Canal was a ditch in the $100-F$ Area that routinely received a variety of liquid wastes from 1953 to 1965 . During the ball $3 X$ outage of 1953, this ditch was used to drain effluent water to the Columbia River. The 100-F ball-washer crib received liquid wastes from the 
boron steel-ball decontamination operations. Finally, the 1706-KER crib received liquid wastes from cleanup of the columns in the 1706KER 1oop (Dorian and Richards 1978).

A listing of the miscellaneous cribs and trenches in the 100 Areas is given in Table 3.2.1. Information in this table is based on information reported by Dorian and Richards (1978).

\subsubsection{Radiological Characteristics of the Miscellaneous Cribs and Trenches}

The miscellaneous cribs and trenches in the 100 Areas received a variety of liquid wastes resulting from fuel failures and decontamination operations. The general conclusions of the radiological characterization program for these cribs and trenches reported by Dorian and Richards (1978) are:

- beta-gamma contamination levels range from $10^{-1}$ to $10^{6} \mathrm{pCi} / \mathrm{g}$

- radionuclide concentrations and inventories are lowest in the 117 cribs, and highest in the 108-B crib, 115-K cribs, and the 105-C pluto crib and sand filter

- the principal radionuclides are ${ }^{3} \mathrm{H},{ }^{14} \mathrm{C},{ }^{60} \mathrm{Co},{ }^{90} \mathrm{Sr},{ }^{137} \mathrm{Cs},{ }^{152 \mathrm{E} u}$, $154 \mathrm{Eu}$, and 239/240pu

- 239/240 pu contamination levels are generally less than $1 \mathrm{pCi} / \mathrm{g}$, except for the 105-C crib sand filter where the concentration levels range up to about $10^{3} \mathrm{pCi} / \mathrm{g}$

- total radionuclide inventories for individual facilities range from $10^{-3} \mathrm{Ci}$ to about $300 \mathrm{Ci}$

- contamination levels generally approach background levels within $2 \mathrm{~m}$ to $6 \mathrm{~m}$ below the bottoms of the cribs or trenches.

A representative radionuclide inventory for the miscellaneous cribs and trenches is given in Table 3.2.2. The radionuclides and relative concentrations shown in this table were developed based on the monitoring 
Table 3.2.1 Miscellaneous Cribs and Trenches in the $100 \operatorname{Areas}(a)$

\begin{tabular}{|c|c|c|}
\hline Designation & Number & Area \\
\hline 105 Storage Basin Trenches & $\begin{array}{l}116-B-2 \\
116-D-1 A \\
116-D-1 B \\
116-D R-3 \\
116-F-3\end{array}$ & $\begin{array}{l}100-B \\
100-D \\
100-D \\
100-D R \\
100-F\end{array}$ \\
\hline 105 Pluto Cribs & $\begin{array}{l}116-B-3 \\
116-C-2 \\
116-D-2 \\
116-D R-4 \\
116-F-4 \\
116-H-4\end{array}$ & $\begin{array}{l}100-B \\
100-C \\
100-D \\
100-D R \\
100-F \\
100-H\end{array}$ \\
\hline $\begin{array}{l}105 \text { Dummy/Perf (b) } \\
\text { Decontamination Cribs }\end{array}$ & $\begin{array}{l}116-B-4 \\
116-F-10 \\
116-H-3\end{array}$ & $\begin{array}{l}100-B \\
100-F \\
100-H\end{array}$ \\
\hline $\begin{array}{l}1608 \text { Liquid Waste Disposal } \\
\text { Trenches }\end{array}$ & $\begin{array}{l}116-F-6 \\
116-H-2\end{array}$ & $\begin{array}{l}100-\mathrm{F} \\
100-\mathrm{H}\end{array}$ \\
\hline 115 Cribs & $\begin{array}{l}116-K E-1 \\
116-K W-2\end{array}$ & $\begin{array}{l}100-K E \\
100-K W\end{array}$ \\
\hline 117 Cribs & $116-F-7$ & $\begin{array}{l}100-F \\
100-H \\
100-D \\
100-D R\end{array}$ \\
\hline 108 Cribs & $\begin{array}{l}116-B-5 \\
116-D-3 \\
116-D-4\end{array}$ & $\begin{array}{l}100-B \\
100-D \\
100-D\end{array}$ \\
\hline \multicolumn{3}{|l|}{ other } \\
\hline $\begin{array}{l}\text { Lewis Canal } \\
\text { Ba11 Washer Crib } \\
1706-\text { KER Crib }\end{array}$ & $\begin{array}{l}116-F-1 \\
116-F-5 \\
116-K E-2\end{array}$ & $\begin{array}{l}100-F \\
100-F \\
100-K E\end{array}$ \\
\hline
\end{tabular}

(a) Based on data reported by Dorian and Richards (1978).

(b) A concrete slab over the crib prohibited sampling. 
Table 3.2.2. Representative Radionuclide Inventory for the Miscellaneous Cribs and Trenches

\begin{tabular}{|c|c|c|c|}
\hline Radionuclide (a) & $\begin{array}{c}\text { Relative Activity } \\
\text { at } \mathrm{T}=0 \mathrm{yr} \\
(\mathrm{pC} \mathrm{C} / \mathrm{g}) \\
\end{array}$ & $\begin{array}{l}\text { Relative Activity } \\
\text { Decayed to } \\
T=100 \mathrm{yr} \\
(\mathrm{pCi} / \mathrm{g})\end{array}$ & $\begin{array}{c}\text { Relative Activity } \\
\text { Decayed to } \\
T=300 \mathrm{yr} \\
(\mathrm{pCi} / \mathrm{g})\end{array}$ \\
\hline $\begin{array}{l}{ }^{3} \mathrm{H} \\
1{ }^{4} \mathrm{C} \\
{ }^{60} \mathrm{Co}\end{array}$ & $\begin{array}{l}1.2 E-2(b) \\
2.2 E-1 \\
2.2 E-1\end{array}$ & $\begin{array}{l}5.0 E-5 \\
2.2 E-1 \\
4.3 E-7\end{array}$ & $\begin{array}{l}8.7 \mathrm{E}-10 \\
2.1 \mathrm{E}-1 \\
1.6 \mathrm{E}-18\end{array}$ \\
\hline $\begin{array}{l}{ }^{90} \mathrm{Sr}+\mathrm{D}(\mathrm{c}) \\
137 \mathrm{Cs}+\mathrm{D} \\
152 \mathrm{Eu}\end{array}$ & $\begin{array}{l}8.5 \mathrm{E}-2 \\
3.3 \mathrm{E}-1 \\
1.2 \mathrm{E}-1\end{array}$ & $\begin{array}{l}6.8 E-3 \\
3.3 E-2 \\
7.2 E-4\end{array}$ & $\begin{array}{l}4.4 E-5 \\
3.3 E-4 \\
2.6 E-8\end{array}$ \\
\hline $\begin{array}{l}154 \mathrm{Eu} \\
238 \mathrm{U}+\mathrm{D} \\
238 \mathrm{Pu}\end{array}$ & $\begin{array}{l}3.7 E-3 \\
7.9 E-5 \\
9.1 E-5\end{array}$ & $\begin{array}{l}1.2 E-6 \\
7.9 E-5 \\
4.1 E-5\end{array}$ & $\begin{array}{l}1.3 \mathrm{E}-13 \\
7.9 \mathrm{E}-5 \\
8.2 \mathrm{E}-6\end{array}$ \\
\hline $239 \mathrm{Pu}$ & $6.7 E-3$ & $6.7 E-3$ & $6.7 E-3$ \\
\hline Totals & 1.0 & 0.26 & 0.22 \\
\hline
\end{tabular}

(a) Based on information from Dorian and Richards (1978).

(b) Where $1.2 \mathrm{E}-2=1.2 \times 10^{-2}$.

(c) $+D$ means plus short-lived daughter products.

data reported for miscellaneous cribs and trenches by Dorian and Richards (1978) normalized to $1 \mathrm{pCi} / \mathrm{g}$.

\subsection{SOLID-WASTE BURIAL GROUNDS}

A total of 25 solid-waste disposal sites have been identified in the 100 Areas of the Hanford Site (Harmon and King 1975). All of these sites have been retired since the early or mid 1970's, and all wastes generated since that time have been sent to the 200 Area waste sites for disposal. The following sections contain brief descriptions of the physical and radiological characteristics of the solid waste burial grounds in the 100 Areas of the Hanford Site. 


\subsubsection{Physical Description of the Solid-Waste Burial Grounds}

Solid-waste burial grounds in the 100 Areas simply consist of unlined trenches that are filled with solid, radioactive wastes and covered with a meter or more of soil. A listing of the 25 solid-waste burial grounds in the 100 Areas is given in Table 3.3.1 (Dorian and Richards 1978). The total volume of waste contained in these burial grounds is not accurately known; however, the burial grounds are estimated to cover about 26 hectares (65 acres) (Harmon and King 1975).

\subsubsection{Radiological Characteristics of the Solid-Waste Burial Grounds}

Prior to 1967, only very limited records were kept of the solid waste volumes and total radionuclide contents disposed of in the 100 Areas. Current estimates are that a total of about $27,000 \mathrm{Ci}$ of $60 \mathrm{Co}, 34$ of $\mathrm{Ci}$ of $90 \mathrm{Sr}$, and $0.3 \mathrm{Ci}$ of $239 \mathrm{Pu}$ were disposed in the 100 Area solid-waste burial grounds (Dorian and Richards 1978). The general conclusions of the radiological characterization program reported by Dorian and Richards (1978) are:

- $239 / 240 p u$ is generally not detectable, with a maximum concentration of $1 \mathrm{pCi} / \mathrm{g}$

- the primary radionuclide identified was ${ }^{60} \mathrm{Co}$ with lesser amounts of $63 \mathrm{Ni}, 90 \mathrm{Sr}, 137 \mathrm{Cs}, 152 \mathrm{Eu}$, and $154 \mathrm{Eu}$

- the maximum beta-gamma concentration encountered was $1.8 \times 10^{5} \mathrm{pCi} / \mathrm{g}$, of which $1.7 \times 10^{5} \mathrm{pCi} / \mathrm{g}$ was ${ }^{60} \mathrm{Co}$

- the maximum detected 1 evel of $63 \mathrm{Ni}$ was about $75 \mathrm{pCi} / \mathrm{g}$; however, it is probably present in greater concentrations in metallic wastes within the burial grounds

- no measurable migration of radionuclides is indicated by the monitoring data 
Table 3.3.1. Solid Waste Burial Grounds in the 100 Areas(a)

\begin{tabular}{|c|c|c|}
\hline Number & Title & $\begin{array}{c}\text { Appproximate } \\
\text { Dimensions (m) }\end{array}$ \\
\hline $\begin{array}{l}118-B-1 \\
118-B-2 \\
118-B-3\end{array}$ & $\begin{array}{l}\text { 105-B Burial Ground } \\
\text { Construction Burial Ground No. } 1 \\
\text { Construction Burial Ground No. } 2\end{array}$ & $\begin{aligned} & 300 \times 98 \\
& 18 \times 9 \\
& 100 \times 84\end{aligned}$ \\
\hline $\begin{array}{l}118-B-4 \\
118-B-5 \\
118-B-6\end{array}$ & $\begin{array}{l}\text { 105-B Dummy Storage Burial Ground } \\
\text { Ball 3X Burial Gound } \\
\text { 108-B Solid Waste Burial Ground }\end{array}$ & $\begin{array}{l}15 \times 9 \\
15 \times 15 \\
12 \times 12\end{array}$ \\
\hline $\begin{array}{l}118-C-1 \\
118-D-1 \\
118-D-2\end{array}$ & $\begin{array}{l}\text { 105-C Burial Ground } \\
100-D \text { Burial Ground No. } 1 \\
100-D \text { Burial Ground No. } 2\end{array}$ & $\begin{array}{l}160 \times 120 \\
140 \times 110 \\
300 \times 110\end{array}$ \\
\hline $\begin{array}{l}118-D-3 \\
118-D-4 \\
118-D-5\end{array}$ & $\begin{array}{l}\text { 100-D Burial Ground No. } 3 \\
\text { Construction Burial Ground } \\
\text { Ball 3X Burial Ground }\end{array}$ & $\begin{aligned} 300 & \times 76 \\
180 & \times 60 \\
6 & \times 6\end{aligned}$ \\
\hline $\begin{array}{l}118-D R-1 \\
118-F-1 \\
118-F-2\end{array}$ & $\begin{array}{l}\text { 105-DR Gas Loop Burial Ground } \\
\text { Solid-Waste Burial ground No. 2; } \\
\text { Minor construction Burial Ground No. } 2 \\
\text { Burial Ground No. } 2 \text { (Solid-Waste Burial } \\
\text { Ground No. 1) }\end{array}$ & $\begin{array}{r}38 \times 23 \\
180 \times 150 \\
110 \times 100\end{array}$ \\
\hline $\begin{array}{l}118-F-3 \\
118-F-4 \\
118-F-5(b)\end{array}$ & $\begin{array}{l}\text { Burial Ground No. } 3 \text { (Minor Construction } \\
\text { Burial Ground No. 1) } \\
115-F \text { Pit } \\
\text { PNL Sawdust Repository }\end{array}$ & $\begin{aligned} 53 & \times 15 \\
3 & \times 3 \\
150 & \times 46\end{aligned}$ \\
\hline $\begin{array}{l}118-F-6(b) \\
118-H-1 \\
118-H-2\end{array}$ & $\begin{array}{l}\text { Solid-Waste Burial Ground } \\
100-\mathrm{H} \text { Burial Ground No. } 1 \\
100-\mathrm{H} \text { Burial Ground No. } 2 \text { (H-1 Loop } \\
\text { Burial Ground) }\end{array}$ & $\begin{array}{l}120 \times 60 \\
210 \times 100 \\
43 \times 15\end{array}$ \\
\hline $\begin{array}{l}118-H-3 \\
118-H-4 \\
118-H-5\end{array}$ & $\begin{array}{l}\text { Construction Burial Ground } \\
\text { Bal1 3X Burial Ground } \\
\text { 105-H Thimble Pit }\end{array}$ & $\begin{aligned} 90 & \times 60 \\
46 & \times 9 \\
9 & \times 0.6\end{aligned}$ \\
\hline $118-K$ & K Burial Ground & $360 \times 180$ \\
\hline
\end{tabular}


A representative radionuclide inventory for the solid-waste burial grounds in the 100 Areas is given in Table 3.3.2. The radionuclides and relative concentrations shown in this table were developed based on the monitoring data reported by Dorian and Richards (1978) and by Harmon and King (1975) normalized to $1 \mathrm{pCi} / \mathrm{g}$.

\subsection{NUCLEAR REACTORS}

A total of nine production reactors are located in the 100 Areas of the Hanford Site. All of the reactors operated at high power levels, and al 1 reactor buildings are designated as 105 buildings. Eight of the reactors have been deactivated $(105-F,-H,-D,-D R,-B,-C,-K E$, and $-K W)$ and one reactor $(100-N)$ is still in operation. The following sections contain brief physical and radiological descriptions of the retired production reactors at the Hanford Site.

Table 3.3.2. Representative Radionuclide Inventory for the Solid Waste Burial Grounds(a)

\begin{tabular}{|c|c|c|c|}
\hline Radionuclide(a) & $\begin{array}{c}\text { Relative Activity } \\
\text { at } T=0 \text { yr } \\
(\mathrm{pC} i / g) \\
\end{array}$ & $\begin{array}{c}\text { Relative Activity } \\
\text { Decayed to } \\
T=100 \mathrm{yr} \\
(\mathrm{pCi} / \mathrm{g})\end{array}$ & $\begin{array}{c}\text { Relative Activity } \\
\text { Decayed to } \\
T=300 \mathrm{yr} \\
(\mathrm{pci} / \mathrm{g})\end{array}$ \\
\hline $\begin{array}{l}60 \mathrm{Co} \\
6{ }^{6} \mathrm{Ni} \\
{ }^{90} \mathrm{Sr}+\mathrm{D}(\mathrm{C})\end{array}$ & $\begin{array}{l}9.1 E-1(b) \\
8.7 E-3 \\
1.6 E-2\end{array}$ & $\begin{array}{l}1.8 E-6 \\
4.4 E-3 \\
1.3 E-3\end{array}$ & $\begin{array}{l}6.7 \mathrm{E}-18 \\
1.0 \mathrm{E}-3 \\
8.3 \mathrm{E}-6\end{array}$ \\
\hline $\begin{array}{l}137 \mathrm{Cs}+\mathrm{D} \\
152 \mathrm{Eu} \\
154 \mathrm{Eu}\end{array}$ & $\begin{array}{l}1.3 E-2 \\
9.2 E-2 \\
4.2 E-2\end{array}$ & $\begin{array}{l}1.3 E-3 \\
5.5 E-4 \\
1.4 E-5\end{array}$ & $\begin{array}{l}1.3 E-5 \\
6.7 E-9 \\
1.4 E-12\end{array}$ \\
\hline $\begin{array}{l}238 u+D \\
239 \mathrm{Pu} \\
\end{array}$ & $\begin{array}{l}1.8 E-5 \\
1.1 E-4 \\
\end{array}$ & $\begin{array}{l}1.8 E-5 \\
1.1 E-4 \\
\end{array}$ & $\begin{array}{l}1.8 \mathrm{E}-5 \\
1.1 \mathrm{E}-4 \\
\end{array}$ \\
\hline Totals & 1.0 & 0.0077 & 0.0012 \\
\hline
\end{tabular}

(a) Based on information from Dorian and Richards (1978).

(b) Where $9.1 \mathrm{E}-1=9.1 \times 10^{-1}$.

(c) $+D$ means plus short-lived daughter products. 


\subsubsection{Physical Description of the Nuclear Reactors}

The production reactors at the Hanford Site are all graphite-moderated reactors that operated using Columbia River water as a once-through coolant. A typical layout of a reactor building is shown in Figure 3.4.1 (General Electric Co. 1963). The reactor is located in the center of the building (item 9 in Figure 3.4.1). Massive reinforced concrete wall construction is used in areas around the reactor block to provide radiation shielding. More detailed information concerning the design and construction features of the Hanford production reactors can be found in documents by Harmon and King (1975) and Dorian and Richards (1978).

\subsubsection{Radiological Characteristics of the Nuclear Reactors}

The retired production reactors contain large inventories of radioactive materials. Most of the residual radioactivity is associated with the reactor cores including the graphite moderator blocks, and thermal and biological shields. As a result, the sampling programs conducted to date have concentrated on characterization of the reactor cores. General findings of the radiological characterization program reported by Dorian and Richards (1978) for the 105-DR reactor include:

- in-situ dose rates at the outer surface of the thermal shield were about $2 \mathrm{R} / \mathrm{h}$, with a maximum in-situ reader-core dose rate of $100 \mathrm{R} / \mathrm{h}$

- the inventory of the thermal shield is about $17,000 \mathrm{Ci}$ consisting mostly of $60 \mathrm{Co}$ and $63 \mathrm{Ni}$

- the graphite moderator blocks contain about 18,000 Ci consisting of about $67 \% 3 \mathrm{H}$, and $27 \% 14 \mathrm{C}$

- average $239 / 240 \mathrm{pu}$ concentrations are about $2.6 \times 10^{3} \mathrm{pCi} / \mathrm{g}$, with a maximum of $2.7 \times 10^{4} \mathrm{pCi} / \mathrm{g}$

- ${ }^{60} \mathrm{Co}$ concentrations in the process tubes are about $2.5 \times 10^{7} \mathrm{pCi} / \mathrm{g}$.

A representative radionuclide inventory for the Hanford nuclear reactors is shown in Table 3.4.1. The radionuclide relative concentrations shown are based on the monitoring data presented by Dorian and Richards (1978). 
1. CONTROL ROOM

2. OFFICES

3. CONFERENCE ROOM

4. LUNCH ROOM

5. CHANGE AREA \& CLEAN CLOTHES STORAGE

6. SHOPS

7. OFFICES

8. FRONT WORK AREA

9. REACTOR BLOCK

10. EXPERIMENTAL LEVELS

11. TOP OF UNIT \& VSR PATTERN

12. DISCHARGE AREA

13. STORAGE AREA

14. HORIZONTAL CONTROL ROD INNER \& OUTER ROOMS

15. VENTILATION EXHAUST FAN ROOM

16. VENTILATION SUPPLY FAN ROOM

FIGURE 3.4.1. Typical Reactor Building Layout - 105-K Reactor (General Electric Co. 1963) 
Table 3.4.1. Representative Radionuclide Inventory for the Nuclear Reactors

\begin{tabular}{|c|c|c|c|}
\hline Radionuclide (a) & $\begin{array}{l}\text { Relative Activity } \\
\text { at } \mathrm{T}=0 \mathrm{yr} \\
\left(\mathrm{Ci} / \mathrm{m}^{2} \text { or } \mathrm{pCi} / \mathrm{g}\right)\end{array}$ & $\begin{array}{c}\text { Relative Activity } \\
\text { Decayed to } \\
\mathrm{T}=100 \mathrm{yr} \\
\left(\mathrm{Ci} / \mathrm{m}^{2} \text { or } \mathrm{pCi} / \mathrm{g}\right) \\
\end{array}$ & $\begin{array}{c}\text { Relative Activity } \\
\text { Decayed to } \\
T=300 \mathrm{yr} \\
\left(\mathrm{Ci} / \mathrm{m}^{2} \text { or } \mathrm{pCi} / \mathrm{g}\right)\end{array}$ \\
\hline $\begin{array}{l}{ }^{3} \mathrm{H} \\
{ }^{14} \mathrm{C} \\
{ }^{60} \mathrm{Co}\end{array}$ & $\begin{array}{l}6.5 \mathrm{E}-1(\mathrm{~b}) \\
2.7 \mathrm{E}-1 \\
8.2 \mathrm{E}-3\end{array}$ & $\begin{array}{l}2.7 \mathrm{E}-3 \\
2.7 \mathrm{E}-1 \\
1.6 \mathrm{E}-8\end{array}$ & $\begin{array}{l}4.7 \mathrm{E}-8 \\
2.6 \mathrm{E}-1 \\
6.1 \mathrm{E}-20\end{array}$ \\
\hline $\begin{array}{l}{ }^{63} \mathrm{Ni} \\
90 \mathrm{Sr}+\mathrm{D}(\mathrm{C}) \\
137 \mathrm{Cs+D}\end{array}$ & $\begin{array}{l}8.0 \mathrm{E}-3 \\
5.5 \mathrm{E}-2 \\
3.0 \mathrm{E}-3\end{array}$ & $\begin{array}{l}4.0 E-3 \\
4.5 E-2 \\
3.0 E-4\end{array}$ & $\begin{array}{l}1.0 \mathrm{E}-3 \\
2.8 \mathrm{E}-5 \\
3.0 \mathrm{E}-6\end{array}$ \\
\hline $\begin{array}{l}152 \mathrm{Eu} \\
154 \mathrm{Eu} \\
238 \mathrm{U}+\mathrm{D}\end{array}$ & $\begin{array}{l}5.3 \mathrm{E}-3 \\
4.1 \mathrm{E}-3 \\
1.6 \mathrm{E}-8\end{array}$ & $\begin{array}{l}4.3 E-4 \\
2.5 E-5 \\
1.6 E-8\end{array}$ & $\begin{array}{l}2.8 \mathrm{E}-6 \\
8.9 \mathrm{E}-10 \\
1.6 \mathrm{E}-8\end{array}$ \\
\hline $\begin{array}{l}238 \mathrm{Pu} \\
239 \mathrm{Pu} \\
241 \mathrm{Am}\end{array}$ & $\begin{array}{l}3.9 E-4 \\
2.5 E-4 \\
3.6 E-4\end{array}$ & $\begin{array}{l}3.1 E-4 \\
2.5 E-4 \\
3.1 E-4\end{array}$ & $\begin{array}{l}3.5 \mathrm{E}-5 \\
2.5 \mathrm{E}-4 \\
2.2 \mathrm{E}-4\end{array}$ \\
\hline Totals & 1.0 & 0.32 & 0.26 \\
\hline
\end{tabular}

(a) Based on information from Dorian and Richards (1978).

(b) Where $6.5 \mathrm{E}-1=6.5 \times 10^{-1}$.

(c) $+D$ means plus short-lived daughter products.

\subsection{FUEL-STORAGE BASINS}

Fuel-storage basins are located in each of the 105 reactor buildings. They provided collection, storage, and transfer facilities for the irradiated fuel elements from the reactor (Harmon and King 1975). The storage basins are of concrete construction, with a depth of about $6 \mathrm{~m}$ of water to provide both shielding and coolant for the irradiated fuel. Brief physical and radiological descriptions of the fuel-storage basins are given in the following sections. 


\subsubsection{Physical Description of the Fuel-Storage Basins}

The reactor fuel-storage basins are typically divided into three areas. These are the metal pickup area, the storage area, and the transfer area. Each basin has a wash pad, and an underwater fuel-inspection facility was included in some of the basins. The fuel-storage basins covered from $650 \mathrm{~m}^{2}$ to $930 \mathrm{~m}^{2}$, depending on the specific reactor. A considerable layer of sludge developed the floor of the basins over several years of operations. This sludge contains transuranics and fusion products as well as activated materials from the reactor coolant. The basins in the 105-F and 105-H reactor buildings were filled with soil at the time of retirement. Side and top views of typical fuel-storage basins are shown in Figure 3.5.1 (Harmon and King 1975).

\subsubsection{Radiological Characteristics of the Fuel Storage Basins}

Radiological characterization samples of the sludge and water samples were taken in a program that started during 1975. The following general survey findings were reported by Dorian and Richards (1978):

- a maximum concentration of $239 / 240 \mathrm{pu}$ was reported as $9.5 \times 104 \mathrm{pCi} / \mathrm{g}$ for a sludge sample taken from the 105-B basin

- average $239 / 240 \mathrm{Pu}$ concentrations for the 105-B and $-\mathrm{C}$ basin are about $3.0 \times 10^{4} \mathrm{pCi} / \mathrm{g}$

- beta-gamma concentrations in the basin sludge averages about $2.2 \times 10^{6}$ $\mathrm{pCi} / \mathrm{g}$

- the primary beta-gamma radionuclides present in the sludge are ${ }^{60} \mathrm{Co}$, $63 \mathrm{Ni}, 90 \mathrm{Sr}, 137 \mathrm{Cs}, 152 \mathrm{Eu}$, and $154 \mathrm{Eu}$

- the total radionuclide inventory in the sludge in each basin ranges from $94 \mathrm{Ci}$ to $150 \mathrm{Ci}$.

A representative radionuclide inventory for the fuel-storage basins is given in Table 3.5.1. The radionuclides and relative concentrations shown are based on the sludge sample data presented by Dorian and Richards (1978) normalized to $1 \mathrm{pCi} / \mathrm{g}$. 

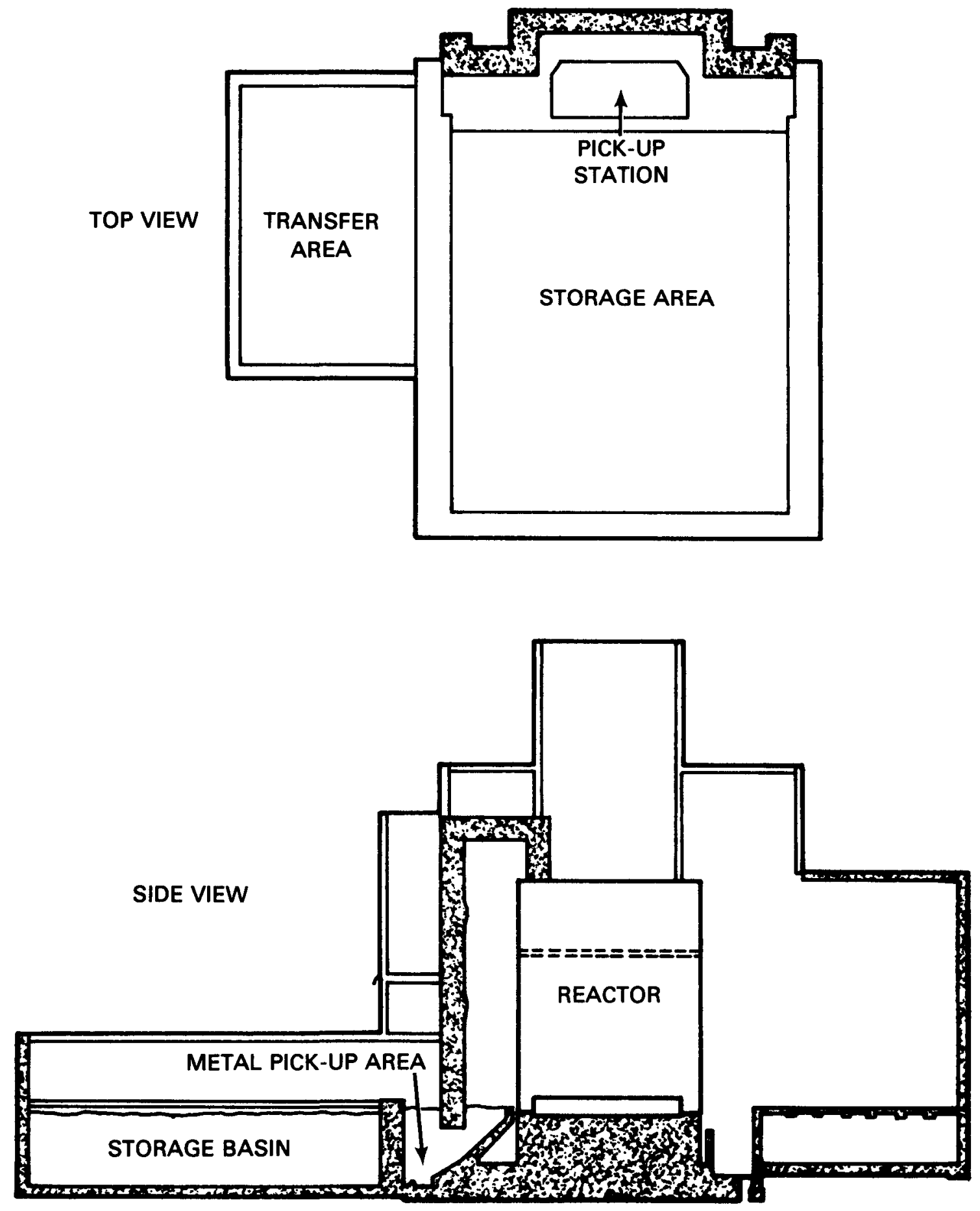

FIGURE 3.5.1. Typical Fuel-Storage Basins in the 100 Areas (Harmon and King 1975) 
Table 3.5.1. Representative Radionuclide Inventory for the Fuel Storage Basins

\begin{tabular}{|c|c|c|c|}
\hline Radionuclide (a) & $\begin{array}{c}\text { Relative Activity } \\
\text { at } \mathrm{T}=0 \mathrm{yr} \\
\left(\mathrm{Ci} / \mathrm{m}^{2} \text { or } \mathrm{pCi} / \mathrm{g}\right)\end{array}$ & $\begin{array}{c}\text { Relative Activity } \\
\text { Decayed to } \\
\mathrm{T}=100 \mathrm{yr} \\
\left(\mathrm{Ci} / \mathrm{m}^{2} \text { or } \mathrm{pCi} / \mathrm{g}\right)\end{array}$ & $\begin{array}{c}\text { Relative Activity } \\
\text { Decayed to } \\
T=300 \mathrm{yr} \\
\left(\mathrm{Ci} / \mathrm{m}^{2} \text { or } \mathrm{pCi} / \mathrm{g}\right)\end{array}$ \\
\hline${ }^{3} H$ & $3.5 E-10(b)$ & $1.5 \mathrm{E}-12$ & $2.6 \mathrm{E}-17$ \\
\hline${ }^{60} \mathrm{Co}$ & $3.2 E-1$ & $6.2 E-7$ & $2.4 \mathrm{E}-18$ \\
\hline $63 \mathrm{Ni}$ & $2.0 \mathrm{E}-1$ & $1.0 \mathrm{E}-1$ & $2.5 \mathrm{E}-2$ \\
\hline $90 s r+D(c)$ & 1.2E-1 & $9.6 \mathrm{E}-3$ & $6.2 E-5$ \\
\hline $137 C s+D$ & $1.3 E-1$ & $1.3 E-2$ & $1.3 E-4$ \\
\hline $152 \mathrm{Eu}$ & $1.2 E-1$ & $7.2 E-4$ & $2.6 \mathrm{E}-8$ \\
\hline $154 \mathrm{Eu}$ & $9.6 \mathrm{E}-2$ & $3.1 E-5$ & $3.3 E-12$ \\
\hline $238 v+0$ & $6.0 \mathrm{E}-5$ & $6.0 E-5$ & $6.0 E-5$ \\
\hline $238 \mathrm{Pu}$ & $2.8 E-4$ & $1.2 E-4$ & $2.5 E-5$ \\
\hline $239 \mathrm{Pu}$ & 1. $6 \mathrm{E}-2$ & $1.6 \mathrm{E}-2$ & $1.6 \mathrm{E}-2$ \\
\hline Totals & 1.0 & 0.14 & 0.041 \\
\hline
\end{tabular}

(a) Based on information from Dorian and Richards (1978).

(b) Where $3.5 \mathrm{E}-10=3.5 \times 10^{-10}$.

(c) $+D$ means plus short-lived daughters. 


\subsection{RADIATION EXPOSURE SCENARIO ANALYSIS}

The calculations of Allowable Residual Contamination Levels (ARCL) for decommissioning the five categories of facilities in the 100 Areas of the Hanford Site are based on an evaluation of the potential radiation exposures resulting for each of three modes of future use. These modes of use are restricted, controlled, and unrestricted. For restricted and controlled use, institutional controls are assumed to reduce opportunities for exposure by 1 imiting access to the site. Some radioactive materials are left in place and the facilities are left in a safe storage condition. Restricted use is assumed to last for 100 years, and controlled use for 300 years. Exposure scenarios are defined for surface contamination only during the restricted and control led use modes. For unrestricted use, an individual is assumed to have access to any remaining facilities or radioactive materials at the site. Exposure scenarios for both surface and soil contamination are defined for the unrestricted use mode.

Exposures are estimated based upon representative mixtures of radionuclides determined during characterization of the facilities reported by Dorian and Richards (1978) (see Section 3.0), and the exposure scenarios determined for each mode of use. Figure 4.1 .1 contains a summary of the radiation exposure scenarios considered for the three modes of use. For restricted and controlled use, ARCL surface contamination values are calculated for only those categories of facilities that contain structures that could serve as safe-storage facilities. These are the retention-basin systems, nuclear reactors, and fuel-storage basins. Only non-combustible and non-hazardous solid radioactive wastes are assumed to be left in safestorage facilities that provide effective barriers to most types of intrusion. The same procedure is followed to determine ARCL surface contamination values in facilities during unrestricted use. For unrestricted use, the allowable residual contamination levels for each radionuclide are determined using the most restrictive of the scenarios shown in Figure 4.1.1 for both engineered facilities and soil contamination. 
Unconfined (surface) soil and two cases of confined (subsurface) soil contamination are considered for all five categories of facilities in the ARCL calculations. These calculations are intended to represent general soil conditions after decommissioning operations and materials intentionally left under a soil layer. The following sections contain discussions of the radiation exposure scenarios considered for each mode of future use.

\subsection{RESTRICTED USE MODE}

As shown in Figure 4.1.1, the controlling exposure scenario during 100 years of restricted use is the intruder-explorer scenario. Because institutional controls are still in place during restricted use, the exposure conditions for the intruding individual are assumed to be very limited. Only the retention-basin systems, nuclear reactors, and fuelstorage basins are considered in the restricted use calculations. For this scenario, an unauthorized intruder is assumed to gain entry into a safe storage type facility. The intruder is assumed to be motivated by curiosity and is exposed to radiation or radioactive materials by three major pathways. They are direct exposure to penetrating radiation, inhalation of resuspended removable surface contamination, and direct ingestion of removable surface contamination transferred to the hands. For all dose estimates, the individual is assumed to remain in the facility for eight hours.

The direct exposure rate encountered by the intruder for various contamination levels is calculated using the model developed for decommissioning a reference room at a BWR (0ak et a1. 1980). External dose equivalent factors are calculated for the mixtures of radionuclides at the facilities using the ISOSHLD (Engel et al. 1966; Simmons et al. 1967) computer program. Because most of the safe-storage facility is assumed to be filled with radioactive wastes and concrete, access to the facility will be very limited. A sensitivity analysis was conducted for the reference room model to determine the relationship between room size and dose rate (Oak et al. 1980, D. F-16). The results (shown in Figure 4.1.2) indicate a 
dose rate increase by a factor of two or less for 60 co contamination from small to large rooms, assuming that the room has $3-\mathrm{m}$ high walls. For this study, it is assumed that the intruder gains access to a room with dimensions of $6 \times 6 \times 3 \mathrm{~m}$ for his entire exposure period. This room size may be 1 arger than an actual room encountered, but it serves as a reasonable basis for the scenario analysis.

\section{EXPOSURE SCENARIO}

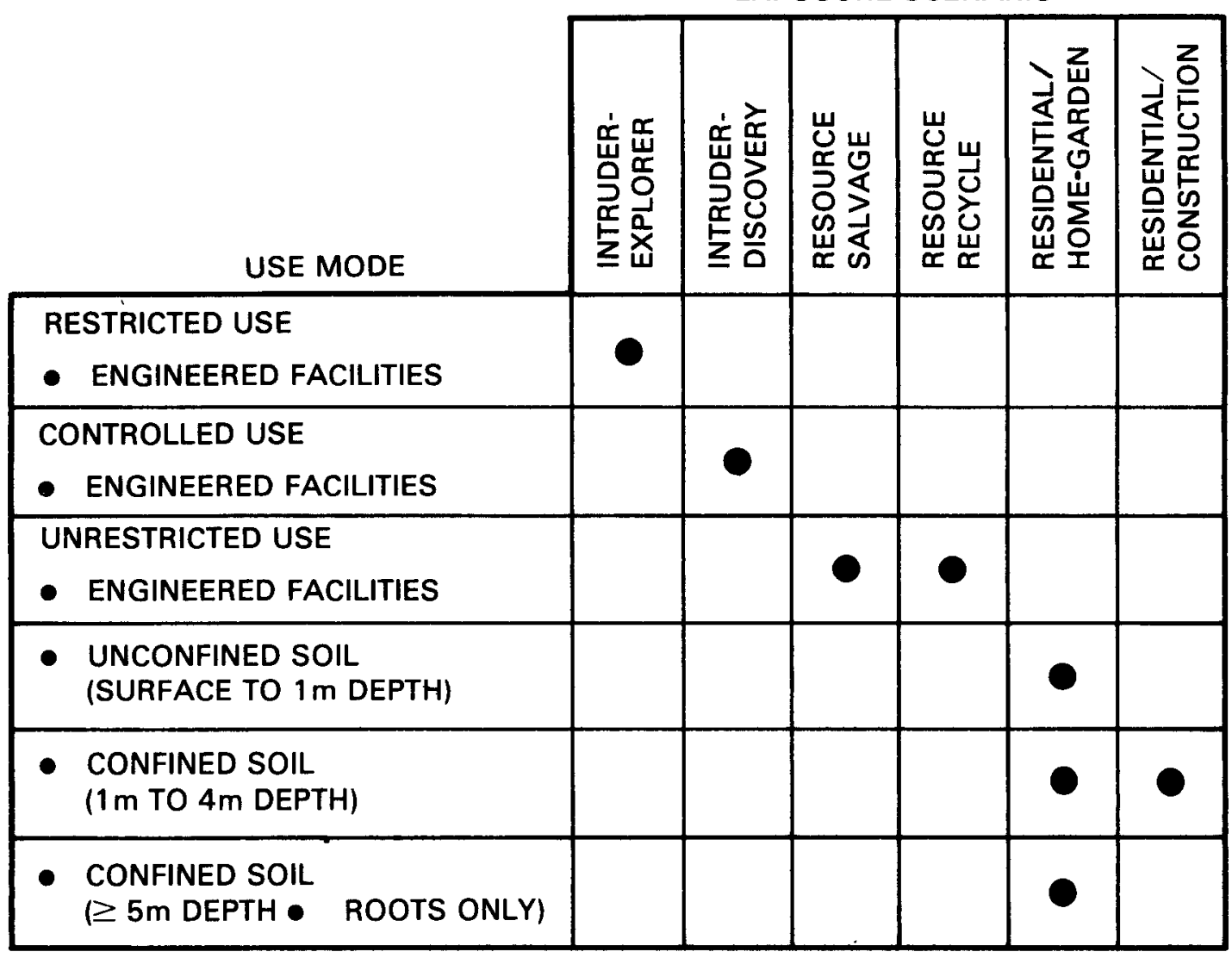

FIGURE 4.1.1. Exposure Scenarios for Decommissioned Facilities in the 100 Areas of the Hanford Site 


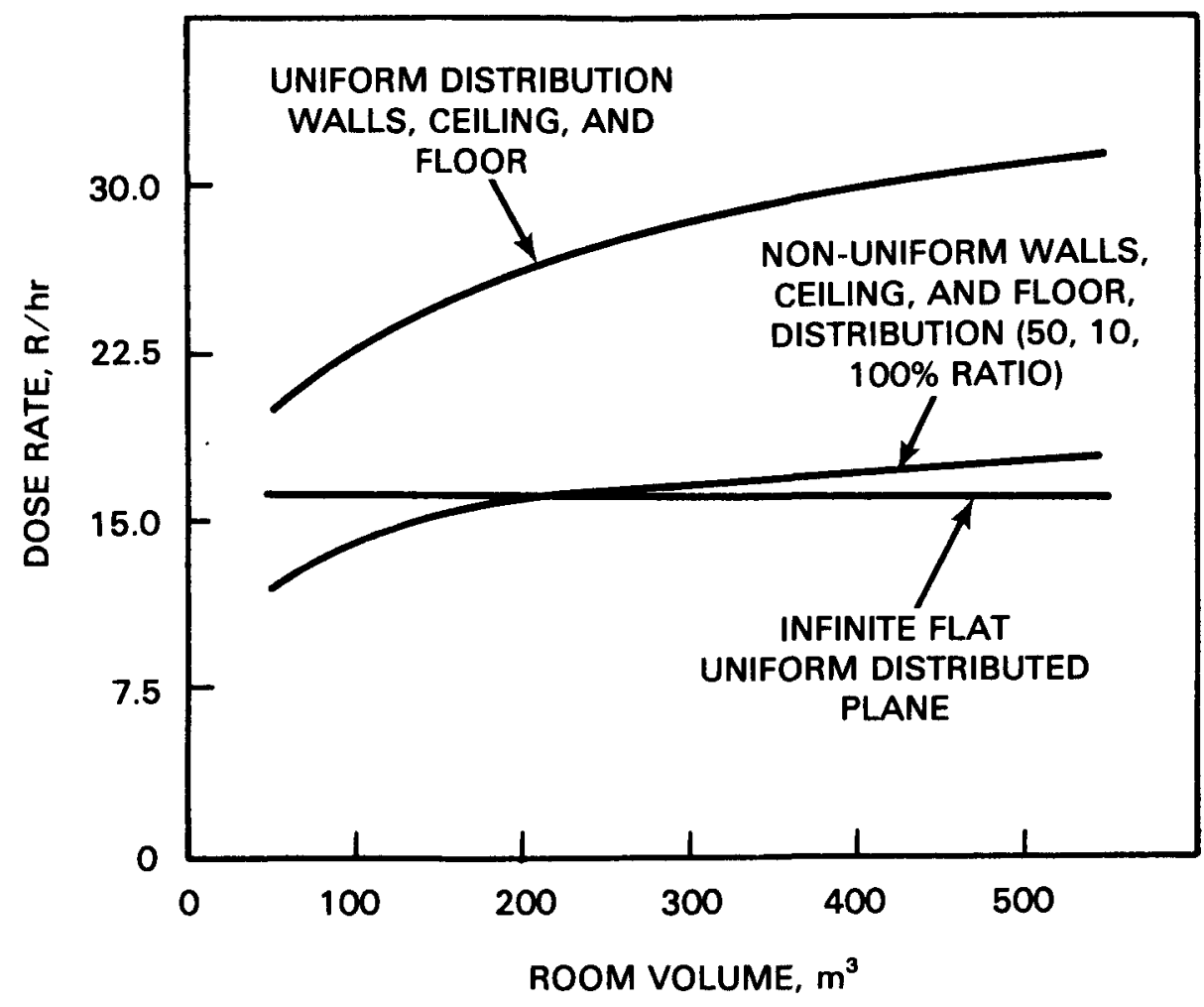

\section{FIGURE 4.1.2. Dose Rate as a Function of Room Volume for a ${ }^{60}$ Co Deposition of $1 \mathrm{Ci} / \mathrm{m}^{2}$ \\ (Oak et al. 1980, p. F-16)}

As a result of the activities of the intruder within the facility, the airborne dust concentration, $x$ in $\mathrm{Ci} / \mathrm{m}^{3}$, is expressed as a function of the resuspension rate and room ventilation by (Healy 1971, p. 80):

$$
x=\frac{f A \Omega}{V n}
$$

where $f$ - the resuspension rate, $h-1$

A - the floor surface area of the room, $\mathrm{m}^{2}$

$\Omega$ - the floor surface contamination level, $\mathrm{Ci} / \mathrm{m}^{2}$

$V$ - the volume of air in the room, $\mathrm{m}^{3}$

$n$ - the rate of room air exchange, $n^{-1}$.

(NOTE: $x / \Omega=K$, the resuspension factor, $m^{-1}$ ) 
The following assumptions are made to calculate the air concentrations from resuspension for the intruder-explorer scenario:

- The average resuspension rate for a vigorous intruder equals $3 \times 10^{-4} \mathrm{~h}^{-1}$ (Healy 1971 , p. 32).

- The room ventilation rate is 1 air exchange per hour, representing a reasonably air-tight room and accounting for the entry way created by the intruder.

- The intruder is assumed to gain access to a room with dimensions of $6 \times 6 \times 3 \mathrm{~m}$, with a total air volume of $100 \mathrm{~m}^{3}$.

The last exposure pathway considered for the intruder-explorer scenario is direct ingestion of removable surface contamination transferred to the hands. Because of a lack of data, previous studies that have considered this pathway have relied on assumed ingestion rates. A summary of the specific assumptions found in previous studies is given in Table 4.1.1. For this study, the intruder is assumed to ingest removable surface contamination at a rate of $10^{-4} \mathrm{~m}^{2} / \mathrm{h}$, for a total of $8 \times 10^{-4} \mathrm{~m}^{2}$ of removable surface contamination during an eight-hour exposure period.

In addition to the three exposure pathways analyzed in this study, a potential fourth pathway was considered, but not analyzed. This pathway is penetration of radionuclides through the skin by either direct absorption (as in the case of $3 \mathrm{H}$ or radionuclides suspended in solvents) or by puncture wounds. The frequency of skin penetration situations is difficult to predict for workers in a radiation zone, and even more difficult to predict for intruders. However, Dunster (1962) concluded that skin penetration events do not need to be taken into account in setting permissible limits of skin contamination if direct irradiation and ingestion of contamination transferred to the hands have been accounted for. Thus, we have made no further attempts to account for skin penetration in this analysis. 
TABLE 4.1.1. Referenced Surface Contamination Ingestion Scenarios

Author and

Reference

Ingestion Rate

Comments

(Dunster 1962) $\quad 10^{-3} \mathrm{~m}^{2} /$ day $\quad$ Chronic ingestion of $(M P C)_{W}$ values of

${ }^{226} \mathrm{Ra},{ }^{90} \mathrm{Sr}$, and $210 \mathrm{pb}$ to derive permissible levels of skin contamination

(Gibson and

Wrixon 1979)

$10^{-3} \mathrm{~m}^{2} /$ day

Chronic ingestion. No data available to improve upon Dunster's model $-(M P C)_{W}$ analysis

(Healy 1971) $\quad 10^{-4} \mathrm{~m}^{2} / \mathrm{h}(8 \mathrm{~h})$

Chronic ingestion during 8 hrs. for workers, $24 \mathrm{hrs}$. for members of the public. These are arbitrary assumptions in an effort to account for presumed higher intake by children, i.e., $2.4 \times 10^{-3} \mathrm{~m}^{2} /$ day.

(Kennedy $\quad 10^{-4} \mathrm{~m}^{2} / \mathrm{h}$

Chronic ingestion of removable surface contamination on transportation containers. Dose estimates for workers and members of the public were reported for radiopharmaceutical, industrial source, nuclear fuel cycle, and lowlevel waste transportation containers.

\subsection{CONTROLLED-USE MODE}

The exposure scenario analyzed for the controlled-use mode (as shown in Figure 4.1.1) is the intruder discovery scenario. Again, controlled-use ARCL values are reported only for the retention-basin systems, nuclear reactors, and fuel-storage basins. The intruder is assumed to enter a safe storage facility and begin salvage operations. His activities are assumed to continue for a total of 20 hours before either he is discovered and removed, or he realizes that he is in a radioactive waste facility and leaves. The intruder is assumed to have the same exposure pathway conditions identified for the intruder-explorer scenario modified to reflect 20 hours of exposure. The exposure pathways considered are direct exposure to 
penetrating radiation, inhalation of resuspended removable surface contami nation, and direct ingestion of removable surface contamination transferred to the hands.

\subsection{UNRESTRICTED-USE MODE}

For unrestricted use, four exposure scenarios have been defined as shown in Figure 4.1.1. They are: resource salvage and resource recycle for surface contamination, and residential/home-garden and residential/ construction for soil contamination. The following sections contain descriptions of these unrestricted-use exposure scenarios.

\subsubsection{RESOURCE SALVAGE EXPOSURE SCENARIO}

This exposure scenario is designed to represent the potential activities of an individual engaged in salvage operations in any part of the facility remaining during the unrestricted use mode. The facilities considered in this scenario are the retention-basin systems, nuclear reactors, and fuel-storage basins. Because there are no controls over the individual, it is assumed that he enters the facility and begins salvage operations without restraint. The individual intruder is assumed to spend $2000 \mathrm{~h}$ during a year working at salvage in the facility. The exposure pathways considered are direct exposure to penetrating radiation, inhalation of resuspended contamination, inhalation of airborne contamination during salvage operations, and ingestion of removable surface contamination transferred to the hands.

The direct exposure rate encountered by the individual is calculated using the same room model and methods discussed for the intruder-explorer scenario, with appropriate modifications for the exposure period. The individual is assumed to work in a room with dimensions of $6 \times 6 \times 3 \mathrm{~m}$ for the entire $2000 \mathrm{~h}$ of exposure.

The resuspended concentration of removable surface contamination is estimated using Equation 4.1 and the same assumptions as 1isted for the intruder-explorer scenario. To estimate the potential impact of inhalation of airborne material during salvage operations, estimates of airborne 
contamination levels are required. For material with surface contamination, the airborne radioactivity during cutting operations is estimated using (Oak et al. 1980, p. N-15):

$$
Q_{C}=L k C_{s}
$$

where $Q_{c}$ - the airborne radioactivity from cutting contaminated pipe or equipment, $\mathrm{Ci}$

$L$ - the length of cut, $m$

$k$ - the kerf width, m

$\mathrm{C}_{s}$ - the surface radioactivity concentration, $\mathrm{Ci} / \mathrm{m}^{2}$.

Equation 4.2 is based on the conservative assumption that all of the surface contamination in the kerf is vaporized and made airborne during the cutting operation. The assumed cutting method is the oxyacetylene torch, and the assumed cutting rate is $10 \mathrm{~m} / \mathrm{h}$. The kerf width for oxyacetylene torch cutting is taken to be $6.4 \times 10^{-3} \mathrm{~m}$ (Oak et al. $1980, \mathrm{p} . \mathrm{N}-14$ ). A total of $400 \mathrm{~h}$ of cutting contaminated piping is assumed for the salvage operations. This equates to about $4000 \mathrm{~m}$ of cut length.

The individual is assumed to ingest removable surface contamination transferred to the hands during salvage operations. The analysis used is similar to that discussed for the intruder-explorer scenario. The individual ingests surface contamination at a rate of $10-4 \mathrm{~m} 2 / \mathrm{h}$ for $2000 \mathrm{~h}$, for a total of $0.2 \mathrm{~m}^{2}$.

\subsubsection{RESOURCE RECYCLE EXPOSURE SCENARIO}

This exposure scenario represents the potential for dose to individuals resulting from distribution of the materials salvaged in the resource salvage scenario. Because there are no restraints on the materials recovered in the unrestricted use mode, these materials are assumed to enter routine commerce. Data presented in the Draft Environmental Statement Concerning Proposed Rulemaking Exemption From Licensing Requirements for Smelted Alloys Containing Residual Technetium-99 and Low-Enriched Uranium (U.S. NRC 1980), indicate that the operations with the greatest 
potential dose to a individual occur during smelting and manufacture of consumer products. During these operations, the worker in a smelter or foundry is exposed to piles of metal scrap, metal ingots, and accumulated finished products. He is additionally exposed to metal fumes and particulates. Radiation dose factors for these operations have been prepared by 0'Donnell et a1. (1978) for a study of dose to man from recycle of metals reclaimed from decommissioned nuclear power plants. From the information in this reference, it appears that the individual with the greatest potential for exposure is one working in a metal scrap yard.

The dose a worker may receive is directly dependent on the quantity of material assumed to be recovered. The individual in the resource salvage scenario is assumed to work $2000 \mathrm{~h} / \mathrm{yr}$. The market price for scrap iron is about $\$ 0.09 / \mathrm{kg}$, so for the individual to make a reasonable income, he would need to recover nearly $200 \mathrm{Mg} / \mathrm{yr}$ of scrap iron (about $1 \mathrm{Mg} /$ day).

This quantity of material is assumed to be melted and made into consumer products (such as frying pans). A factory worker is assumed to work in a scrap yard, as described in 0'Donnell et al. (1978), and to be exposed to the threshold limit value (TLV) of metal particulates $\left(5 \mathrm{mg} / \mathrm{m}^{3}\right)$, for a period 1 ong enough to process $200 \mathrm{Mg}$ of recovered material.

\subsubsection{Residential/Home-Garden Exposure Scenario}

This scenario is designed to represent the unrestricted use exposure conditions of an individual who resides on the site and engages in home gardening activities for 50 years. Unconfined (surface) and confined (subsurface) soil contamination conditions for all five categories of facilities are considered in this scenario. This is done to account for onsite disposal of some contaminated wastes and rubble. The individual is assumed to spend $12 \mathrm{~h} / \mathrm{d}$ outdoors on the site, during which he is exposed to direct penetrating radiation from the soil. The individual is al so assumed to inhale resuspended contamination in the surface soil (if present) for $12 \mathrm{~h} / \mathrm{d}$ during his 50 years of exposure, with an assumed air concentration calculated using a time-dependent resuspension factor to 
account for the environmental "aging" of radionuclides. This relationship is given as (Anspaugh et a1. 1975):

$$
S_{f}=\left(10-4 e^{-\lambda \sqrt{t}}\right)+10-9
$$

$$
\begin{aligned}
\text { where } S_{f} & - \text { resuspension factor } m^{-1} \\
10^{-4} & - \text { resuspension factor at time } t=0, m-1 \\
\lambda & \text { - effective decay constant controlling the availability of } \\
& \text { material for resuspension, } 0.15 \text { day-1/2 } \\
t & \text { - time after deposition, days } \\
10^{-9} & - \text { resuspension factor after } 17 \text { years, } \mathrm{m}^{-1}
\end{aligned}
$$

Finally, the individual is assumed to grow $50 \%$ of his fruit and vegetable diet in a backyard home garden located in the contaminated soil.

As shown in Figure 4.1.1, the residential/home-garden scenario is used to model both unconfined and confined soil contamination scenarios. Unconfined soil contamination is assumed to be in the top meter of soil on the property, with no overburden layer. Two confined soil conditions are assumed, at depths of 1 to $4 \mathrm{~m}$ and depths greater than or equal to $5 \mathrm{~m}$. For the first confined soil condition ( 1 to $4 \mathrm{~m}$ from the surface), a fraction of the buried contamination is as sumed to be brought to the surface as a result of the residential/construction scenario, as discussed in the next section. The radionuclides are assumed to be diluted by uncontaminated soil to $20 \%$ of their original concentrations. For the second confined soil condition ( $\geq 5 \mathrm{~m}$ from the surface) only root penetration is assumed. A root penetration factor of $1 \%$ is assumed based on the work of Napier (1982) as discussed in Section 2.4. This factor means that only $1 \%$ of the plant roots penetrate to or beyond $5 \mathrm{~m}$ from the surface. Thus, the concentrations of radionuclides in the garden crops are $1 \%$ of the concentrations that would result if the contamination were located at the surface.

\subsubsection{Residential/Construction Exposure Scenario}

The residential/construction scenario is based on the intruderconstruction scenario developed by the U.S. Nuclear Regulatory Commission 
in the Draft Environmental Impact Statement in support of 10 CFR Part 61 (U.S. NRC 1981). For this scenario, an individual is assumed to dig a basement for a house into a subsurface radioactive soil (or debris) zone. The radioactive soil is assumed to be $2.5 \mathrm{~m}$ from the surface. Typical surface areas for a house are assumed to be $20 \mathrm{~m}$ by $10 \mathrm{~m}$, for an area of $200 \mathrm{~m}^{2}$. This dimension is assumed for the base of the foundation hole. The foundation hole is assumed to be $3.5 \mathrm{~m}$ deep, with surface dimensions of $26 \mathrm{~m}$ by $16 \mathrm{~m}$. The total excavation is assumed to involve about $200 \mathrm{~m}^{3}$ of contaminated soil mixed with $800 \mathrm{~m}^{3}$ of clean overburden soil. The resulting $1000 \mathrm{~m}^{3}$ mixture has a radionuclide concentration that is $20 \%$ of the original concentration of contaminated soil. The contaminated soil mixture is assumed to be used as fill around the house and distributed uniformly within a $25-\mathrm{m}$ radius around the house.

For the residential/construction scenario, dose estimates are made for the individual both during and after the construction activities. The most restrictive individual doses resulting for both scenarios for each radionuclide are then used in the ARCL calculation. During construction, the individual is assumed to spend 500 hours (over about a 3-month period) on the site. The individual is assumed to inhale air with a dust concentration of $1 \times 10^{-4} \mathrm{~g} / \mathrm{m}^{3}$ be exposed to direct radiation for the 500-hour construction period. After the house is constructed, the individual is assumed to reside there and conduct activities similar to those identified by the NRC for the intruder/agriculture scenario. (U.S. NRC 1981). These conditions are described in Section 4.3.3 for the residential/home-garden scenario. 


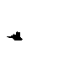




\subsection{ALLOWABLE RESIDUAL CONTAMINATION LEVEL CALCULATIONS}

The step-by-step procedure for calculating Allowable Residual Contamination Levels (ARCL) for the five generic categories of facilities in the 100 Areas at the Hanford Site is outlined in this section. After a brief description of the dose models for assessing exposures by various pathways, ARCL maximum organ dose conversion factors are described for a set of radionuclides of potential interest during decommissioning. Scenariospecific ARCL dose conversion factors for the exposure scenarios considered in this study (Section 4.0) are next developed. The ARCL method applied in this report is intended to use these maximum organ and scenario-specific dose conversion factors since they are based on Hanford-specific modeling methods and data. Finally, specific applications are made for representative mixtures of radionuclides for the five categories of facilities. The procedure described is intended to be flexible enough to permit consideration of alternative mixtures and concentrations of radionuclides, should they be encountered during actual decommissioning operations.

\subsection{DOSE MODELS FOR RADIATION EXPOSURE PATHWAYS}

The method for calculating ARCL values relies on an analysis of maximum annual radiation doses resulting from the limiting radiation exposure scenarios. For short-term exposures, such as those an individual would receive during the intruder-explorer or intruder-discovery scenarios, the maximum annual dose occurs during the year in which the exposure occurs. Dose factors for short-term direct ingestion of surface contamination transferred to the hands are calculated using the ARRRG computer program (Napier et al. 1980). For short-term inhalation, dose factors are obtained using the DACRIN computer program (Houston, Strenge, and Watson 1976). The DACRIN computer program is based on the Task Group on Lung Dynamics Model (TGLM) (ICRP 1966). For this study, a particle size of $1 \mu \mathrm{m}$ activitymedian aerodynamic diameter (AMAD) is assumed. This particle size is within the respirable size distribution and is a "standard" assumption when detailed information on the particle size distribution is not available. To account for the solubility of radionuclides in the blood stream, soluble 
classifications (either Class $D$ or $W$ material) are used for all internal organs except for lung and G.I. tract (lower large intestine), where an insoluble ( $C l a s s ~ W$ or $Y$ ) classification is assumed. These assumptions tend to maximize the dose to specific internal organs obtained from the TGLM equations and are rather "standard" for situations where the exact chemical properties of radionuclides are not known. External exposures are calculated using the BWR room model (0ak et a1. 1980) and dose factors from the ISOSHLD (Engel et a1. 1966; Simmons et a1. 1967) computer program (al so see Section 4.1).

For long-term (or continuous) exposure during the unrestricted use scenarios the maximum annual dose to internal organs may not occur in the first year. This is because specific radionuclides may accumulate in internal organs as a function of their rate of intake and their physical and biological half-lives. The PNL computer program MAXI (Napier et al. 1979; Murphy and Holter 1980) is used in this study to calculate maximum annual doses from continuous exposures. The MAXI program uses dose factors from DACRIN (Houston, Strenge, and Watson 1976) for inhalation, and the FOOD and ARRRG computer programs (Napier et a1. 1980) for ingestion of food products. Further discussions of the mathematical models used in the MAXI computer program are given in documents by Kennedy et a1. (1979), Murphy and Holter (1980), and Napier (1982).

\subsection{ALLOWABLE RESIDUAL CONTAMINATION LEVEL MAXIMUM ORGAN DOSE CONVERSION FACTORS}

By applying the exposure conditions defined in Section 4.0 for the radiation exposure scenarios assigned to each mode of future use, and using the dose models previously discussed, maximum organ dose conversion factors for determining ARCL values are calculated. ARCL dose conversion factors are shown in Table 5.2.1 for specific radiation exposure pathways for radionuclides of potential interest during decommissioning. The dose factors are in units of $\mathrm{rem} / \mathrm{hr}$ per $\mathrm{Ci} / \mathrm{m}^{2}$ for: 1) direct exposure (either in a contaminated room or during resource-recycle operations), 2) inhalation (from resuspension or cutting operations), and 3 ) direct ingestion of contamination transferred to the hands. Inhalation and ingestion dose 


\section{TABLE 5.2.1. Allowable Residual Contamination Level Maximum Organ Dose Conversion Factors}

\begin{tabular}{|c|c|c|c|c|c|c|}
\hline Radionuclide & $\begin{array}{l}\text { Facility: } \\
\text { Direct } \\
\text { Exposure } \\
\text { (rem } / \mathrm{hr} \\
\text { per } \mathrm{Ci} / \mathrm{m}^{2} \text { ) }\end{array}$ & $\begin{array}{l}\text { Inhalation } \\
\text { From Resus- } \\
\text { pension } \\
\text { (rem/hr } \\
\text { per } \mathrm{Ci} / \mathrm{m}^{2}(\mathrm{a})\end{array}$ & $\begin{array}{l}\text { Inhal ation } \\
\text { From Cutting } \\
\text { (rem/hr } \\
\left.\text { per } \mathrm{Ci} / \mathrm{m}^{2}\right)(\mathrm{a}) \\
\end{array}$ & $\begin{array}{l}\text { Inqestion } \\
\text { From Hands } \\
(\text { rem } / \mathrm{hr} \\
\left.\text { per } \mathrm{Ci} / \mathrm{m}^{2}\right)(\mathrm{a})\end{array}$ & $\begin{array}{l}\text { Resource- } \\
\text { Recycle } \\
\text { Direct. } \\
\text { Exposure } \\
\text { (rem/yr } \\
\text { per }\left(i / \mathrm{m}^{2}\right) \\
\end{array}$ & $\begin{array}{l}\text { Residential/ } \\
\text { Home-Garden } \\
\text { (rem/yr } \\
\text { per } \mathrm{pCi} / \mathrm{q})\end{array}$ \\
\hline${ }^{3} \mathrm{H}$ & $-(b)$ & $1.0 E-2(c)$ & $1.2 E-2$ & $6.0 \mathrm{E}-3$ & - & $1.7 \mathrm{E}-10$ \\
\hline${ }^{14} \mathrm{C}$ & - & $2.4 \mathrm{E}-1$ & $2.8 \mathrm{E}-1$ & $2.8 \mathrm{E}-1$ & $3.1 E-4$ & $8.3 E-8$ \\
\hline${ }^{57} \mathrm{Co}$ & $1.4 \mathrm{E}+0$ & $1.2 \mathrm{E}+1$ & 1. $4 \mathrm{E}+1$ & $4.4 E-1$ & $2.7 E+1$ & $2.3 \mathrm{E}-7$ \\
\hline${ }^{60} \mathrm{Co}$ & $2.7 E+1$ & $2.0 \mathrm{E}+2$ & $2.3 E+2$ & $4.4 E+0$ & $4.2 E+2$ & $1.1 \mathrm{E}-2$ \\
\hline $55 \mathrm{Fe}$ & - & $2.4 E+0$ & $2.9 E+0$ & 1.2E-1 & $7.1 \mathrm{E}-3$ & $1.0 E-7$ \\
\hline $59 \mathrm{Fe}$ & $1.3 E+1$ & $2.5 E+1$ & $3.0 E+1$ & $3.8 \mathrm{E}+0$ & $1.5 E+2$ & $1.9 \mathrm{E}-5$ \\
\hline $59 \mathrm{Ni}$ & - & $8.5 E+0$ & $1.0 E+1$ & $3.6 \mathrm{E}+0$ & $3.8 \mathrm{E}-2$ & $5.2 \mathrm{E}-4$ \\
\hline $63 \mathrm{Ni}$ & - & $8.5 E+0$ & $1.0 E+1$ & $3.6 \mathrm{E}+0$ & $3.8 \mathrm{E}-2$ & $5.2 \mathrm{E}-4$ \\
\hline $90 S r+D(d)$ & $1.1 \mathrm{E}-1$ & $3.7 E+2$ & $4.4 \mathrm{E}+2$ & $3.2 \mathrm{E}+1$ & $4.0 E+0$ & $1.1 \mathrm{E}-1$ \\
\hline${ }^{93} \mathrm{Mo}$ & $4.9 \mathrm{E}-2$ & $1.4 \mathrm{E}+1$ & $1.6 \mathrm{E}+1$ & $1.4 \mathrm{E}-1$ & $2.7 E+1$ & $6.0 \mathrm{E}-6$ \\
\hline${ }^{99} \mathrm{TC}$ & - & $2.7 E+1$ & $3.1 E+1$ & $6.6 \mathrm{E}-1$ & $3.3 E-3$ & $3.9 E-4$ \\
\hline $124 \mathrm{Sb}$ & $2.1 E+1$ & $8.3 E+1$ & $9.6 \mathrm{E}+1$ & $8.7 E+0$ & $2.7 E+2$ & $2.7 E-5$ \\
\hline${ }^{125} \mathrm{Sb}+\mathrm{D}$ & $9.0 \mathrm{E}-1$ & $5.6 \mathrm{E}+1$ & $6.5 \mathrm{E}+1$ & $2.2 \mathrm{E}+0$ & $6.7 \mathrm{E}+1$ & $1.7 E-3$ \\
\hline${ }^{134} \mathrm{Cs}$ & $1.9 E+1$ & $2.8 E+1$ & $3.3 E+1$ & $8.8 \mathrm{~F}_{-}+0$ & $2.4 E+2$ & $5.7 \mathrm{E}-3$ \\
\hline $135 \mathrm{Cs}$ & - & $3.9 E+0$ & $4.5 E+0$ & $1.2 \mathrm{E}+0$ & 1. $3 \mathrm{E}-1$ & $9.0 \mathrm{E}-6$ \\
\hline${ }^{137} \mathrm{Cs}+\mathrm{D}$ & $8.9 E+0$ & $5.5 E+0$ & $6.5 E+0$ & $6.5 E+0$ & $1.0 E+2$ & $2.6 \mathrm{E}-3$ \\
\hline $144 \mathrm{Ce}+\mathrm{D}$ & $5.1 \mathrm{E}-1$ & $2.6 E+2$ & $3.0 E+2$ & $9.8 \mathrm{E}+0$ & $8.7 \varepsilon+0$ & $1.3 E-5$ \\
\hline I52Eu & $1.6 \mathrm{E}+1$ & $9.0 \mathrm{E}+1$ & $1.1 \mathrm{E}+2$ & $2.8 \mathrm{E}+0$ & $1.8 E+2$ & $5.0 \mathrm{E}-3$ \\
\hline${ }^{154} \mathrm{Eu}$ & $1.6 \mathrm{E}+1$ & $1.6 \mathrm{E}+2$ & $1.8 \mathrm{E}+2$ & $6.0 E+0$ & $1.9 E+2$ & $5.4 \mathrm{E}-3$ \\
\hline $235 \mathrm{u}+0$ & $2.8 E+0$ & $2.3 E+4$ & $2.8 E+4$ & $4.6 \mathrm{E}+1$ & $2.0 E+1$ & $4.7 E-4$ \\
\hline${ }^{238} \mathrm{U}+\mathrm{D}$ & $7.4 \mathrm{E}-1$ & $2.2 E+4$ & $2.6 E+4$ & $4.4 E+1$ & 1. $2 E+1$ & $4.4 E-4$ \\
\hline $2{ }^{37} \mathrm{~Np}+\mathrm{D}$ & $2.2 E+0$ & $2.4 E+4$ & $3.0 \mathrm{E}+4$ & $1.3 \mathrm{E}+1$ & $1.5 \mathrm{E}+3$ & $7.3 E-4$ \\
\hline $238 \mathrm{Pu}$ & $2.8 \mathrm{E}-3$ & $2.8 E+4$ & $3.4 E+4$ & $8.0 E+0$ & $9.3 E+2$ & $6.1 \mathrm{E}-5$ \\
\hline $239 \mathrm{pu}$ & $1.7 \mathrm{E}-3$ & $2.6 E+4$ & $3.2 E+4$ & $7.5 E+0$ & $1.0 E+3$ & $8.8 \mathrm{E}-5$ \\
\hline $241 \mathrm{Am}$ & $2.2 E+0$ & $2.6 E+4$ & $2.6 E+4$ & $7.8 \mathrm{E}+0$ & $8.9 E+2$ & $1.5 \mathrm{E}-4$ \\
\hline
\end{tabular}

(a) Assuming that all surface contamination is removable, and not fixed.

(b) A dash indicates no dose factors result.

(c) Where $1.0 \mathrm{E}-2=1.0 \times 10^{-2}$.

(d) $+D$ means plus short-lived daughter products. 
factors are calculated based on the conservative assumption that $100 \%$ of each radionuclide is in the form of removable surface contamination. Modifications can be made to these factors to account for fixed surface contamination. For the resource-recycle scenario, the dose factors are rem/yr per $\mathrm{Ci} / \mathrm{m}^{2}$ of contaminated surface, adjusted to a recycle rate of $200 \mathrm{Mg} / \mathrm{yr}$ as described in Section 4.3.2. The resource-recycle dose factors are calculated for the entire year and include both external and inhalation exposure. For soil contamination areas during unrestricted use, the units of these dose factors are given as rem/yr per $\mathrm{pCi} / \mathrm{g}$ of soil, and are directly calculated using the scenario-specific assumptions discussed in Section 4.3.3. Modifications can be made to these soil factors to account for root penetration through a soil or rock barrier.

The dose factors listed in Table 5.2.1 are the largest organ dose for each radionuclide and exposure pathway. The organs considered in the calculations are: total body, bone, 1ung, and G.I. tract (lower large intestine). The dose factors in Table 5.2.1 are used to calculate the scenario-specific ARCL dose factors shown in Table 5.2.2. These factors are given in units of total rem per $\mathrm{Ci} / \mathrm{m}^{2}$ of surface contamination, or total rem/yr per $\mathrm{pCi} / \mathrm{g}$ of soil. They are generally calculated by multiplying the ARCL dose conversion factors in Table 5.2.1 by the hours of exposure for each scenario summed over the pathways considered. For example, the restricted use factors in Table 5.2 .2 are based on $8 \mathrm{~h}$ of exposure as defined by the intruder-explorer scenario. To obtain the factors in Table 5.2.2 for the intruder-explorer, sum the ARCL dose conversion factors in Table 5.2.1 (by radionuclide) for facility direct exposure, inhalation from resuspension, and ingestion from hands; then multiply the sum by eight (reflecting $8 \mathrm{~h}$ of uniform exposure).

The same procedure is followed for the resource-salvage scenario for a 2000-hour period of direct exposure and inhalation from resuspension plus a 400-hour period of inhalation during cutting operations, with the resourcerecycle values added directly. The unconfined soil (to a depth of $1 \mathrm{~m}$ ) maximum annual doses are calculated directly using the scenario-specific data, so no modification is required. Thus, the residential/home-garden 


\section{TABLE 5.2.2. Scenario-Specific A1lowable Residual Contamination Leve1 Dose Factors (a)}

\begin{tabular}{|c|c|c|c|c|c|c|}
\hline \multirow[b]{2}{*}{ Radionuclide } & & & \multicolumn{4}{|c|}{ UNRESTRICTED USE: } \\
\hline & $\begin{array}{l}\text { Restricted Use: } \\
\text { (Total rem } \\
\text { per } \mathrm{C} / \mathrm{m} \mathrm{m}^{2}(\mathrm{~b}) \\
\end{array}$ & $\begin{array}{c}\text { Control led Use: } \\
\text { (Total rem } \\
\text { per } \mathrm{Ci} / \mathrm{m}^{2}(\mathrm{~d}) \\
\end{array}$ & $\begin{array}{l}\text { Column } 3 \\
\text { Composite Surface } \\
\text { Contamination } \\
\text { (Total rem } / y r \\
\text { per }\left(\mathrm{i} / \mathrm{m}^{2}\right)(\mathrm{a}) \\
\end{array}$ & $\begin{array}{c}\text { Column } 4 \\
\text { Unconfined Soil } \\
0-1 \mathrm{~m} \text { Deep } \\
(\text { Total rem } / y r \\
\text { per } p C i / a)(e) \\
\end{array}$ & $\begin{array}{l}\text { Column } 5 \\
\text { Confined Soll } \\
1 \text { to } 4 \mathrm{~m} \mathrm{Deep} \\
(\text { Total } \mathrm{rem} / \mathrm{yr} \\
\text { per } \mathrm{pC}(\mathrm{i} / \mathrm{g})(\mathrm{f}) \\
\end{array}$ & $\begin{array}{c}\text { Column } 6 \\
\text { Confined Soil } \\
5 \text { m Deed } \\
(\text { Total rem } / y r \\
\text { Der } \mathrm{DC} i / g)(q) \\
\end{array}$ \\
\hline${ }^{3 H}$ & $1.3 \mathrm{E}-1(h)$ & $3.2 \mathrm{E}-1$ & $3.7 E+1$ & $1.7 E-10$ & $3.4 E-11$ & $1.7 E-12$ \\
\hline${ }^{14} \mathrm{C}$ & $4.2 E+0$ & $1.0 E+1$ & $1.2 E+3$ & $8.3 E-8$ & $1.7 E-8$ & 8. $3 E-10$ \\
\hline${ }^{57} \mathrm{CO}$ & $1.3 E+2$ & $3.2 E+2$ & $3.4 E+4$ & $2.2 \mathrm{E}-7$ & $4.4 \mathrm{E}-8$ & $2.3 \mathrm{E}-9$ \\
\hline${ }^{60} \mathrm{Co}$ & $1.8 \mathrm{E}+3$ & $4.5 E+3$ & $5.6 \mathrm{E}+5$ & $1.1 \mathrm{E}-2$ & $2.2 E-3$ & $8.9 E-8$ \\
\hline $55 \mathrm{Fe}$ & $2.0 \mathrm{E}+1$ & $5.0 \mathrm{E}+1$ & $6.2 E+3$ & 1. $\cap E-7$ & $2.0 E-8$ & $1.0 \mathrm{E}-10$ \\
\hline${ }^{59} \mathrm{Fe}$ & $3.3 E+2$ & $8.4 E+2$ & $9.6 E+4$ & $1.9 E-5$ & $3.8 \mathrm{E}-6$ & $9.1 \mathrm{E}-12$ \\
\hline $59 \mathrm{NI}$ & $3.0 E+1$ & $7.4 E+1$ & 1. $3 E+4$ & $4.3 \mathrm{E}-5$ & $8.6 \mathrm{E}-6$ & $4.3 E-7$ \\
\hline $63 \mathrm{Ni}$ & $9.7 E+1$ & $2.4 \mathrm{E}+2$ & $2.8 E+4$ & $5.2 \mathrm{E}-4$ & $1.0 \mathrm{E}-4$ & $5.2 E-6$ \\
\hline $90 S r+D(i)$ & $3.2 E+3$ & $8.0 E+3$ & $9.8 E+5$ & $1.1 \mathrm{E}-1$ & $2.2 E-2$ & $1.1 \mathrm{E}-3$ \\
\hline 93 Мо & $1.1 E+2$ & $2.8 E+2$ & $3.5 E+4$ & $6.0 \mathrm{E}-6$ & $1.2 \mathrm{E}-6$ & $6.0 \mathrm{E}-8$ \\
\hline${ }^{99} \mathrm{Tc}$ & $7.4 E+0$ & $1.9 E+1$ & $6.8 E+4$ & $3.9 \mathrm{E}-4$ & $7.8 \mathrm{E}-5$ & $3.9 F-6$ \\
\hline $124 \mathrm{Sb}$ & $9.0 \mathrm{E}+2$ & $2.2 E+3$ & $2.6 \mathrm{E}+6$ & $2.7 \mathrm{E}-5$ & $5.4 \mathrm{E}-6$ & $7.7 E-10$ \\
\hline $125 S b+D$ & $4.7 E+2$ & $1.2 E+3$ & $1.4 E+5$ & $1.7 \mathrm{E}-3$ & $3.4 \mathrm{E}-4$ & $4.1 E-7$ \\
\hline $13{ }^{4} \mathrm{Cs}$ & $4.5 E+2$ & $1.1 \mathrm{E}+3$ & $1.2 \mathrm{E}+5$ & $5.7 \mathrm{E}-3$ & $1.1 \mathrm{E}-3$ & $3.1 \mathrm{E}-7$ \\
\hline${ }^{135} \mathrm{Cs}$ & $4.1 E+1$ & $1.0 E+2$ & $1.2 E+4$ & $9.0 \mathrm{E}-6$ & $1.8 \mathrm{E}-6$ & $9.0 \mathrm{E}-8$ \\
\hline $137 \mathrm{Cs}+0$ & $1.7 E+2$ & $4.2 E+2$ & $4.4 E+4$ & $2.7 \mathrm{E}-3$ & $5.3 E-4$ & $3.3 E-7$ \\
\hline $144 \mathrm{C}+\mathrm{D}$ & $2.2 E+3$ & $5.4 E+3$ & $6.6 E+5$ & $1.3 \mathrm{E}-5$ & $2.6 E-6$ & $8.5 E-11$ \\
\hline $152 \mathrm{Eu}$ & $8.7 E+2$ & $2.2 E+3$ & $2.6 \mathrm{E}+5$ & $5.0 \mathrm{E}-3$ & $1 . \cap E-3$ & 3.0E-10 \\
\hline $154 \mathrm{EU}$ & $1.5 E+3$ & $3.8 E+3$ & $4.4 E+5$ & $5.4 E-3$ & $1.1 \mathrm{E}-3$ & $1.3 E-9$ \\
\hline $235 U+D$ & $1.8 E+5$ & $4.6 \mathrm{E}+5$ & $5.7 E+7$ & $4.7 \mathrm{E}-4$ & $9.4 \mathrm{E}-5$ & $4.6 \mathrm{E}-6$ \\
\hline $238 U+D$ & $1.8 \mathrm{E}+5$ & $4.4 E+5$ & $5.4 E+7$ & 4.4E-4 & $8.8 E-5$ & $4.4 E-6$ \\
\hline $237 \mathrm{~Np}+0$ & $1.9 E+5$ & $4.8 E+5$ & $6.0 E+7$ & $7.3 E-4$ & $1.5 \mathrm{E}-4$ & 7. $3 \mathrm{E}-6$ \\
\hline $238 \mathrm{Pu}$ & $2.2 E+5$ & $5.6 \mathrm{E}+5$ & 7.0E+7 & $6.1 \mathrm{E}-5$ & $1.2 E-5$ & $1.6 \mathrm{E}-7$ \\
\hline $239 \mathrm{pu}$ & $2.1 E+5$ & $5.2 E+5$ & $6.5 E+7$ & $8.8 E-5$ & $1.8 \mathrm{E}-5$ & $2.4 \mathrm{E}-7$ \\
\hline${ }^{241} \mathrm{Am}$ & $2.8 \mathrm{E}+5$ & $7.1 \mathrm{E}+5$ & $8.7 E+7$ & $1.5 \mathrm{E}-4$ & $3.0 \mathrm{E}-5$ & $7.7 \mathrm{E}-7$ \\
\hline
\end{tabular}

\footnotetext{
(a) Based on $1 \mathrm{Ci} / \mathrm{m}^{2}$ of removable surface contamination in the facilities, and 1 pCi/q of soil for unconfined soil areas.

(b) Based on eight hours of exposure in the intruder-explorer scenario (see Section 4.0 ).

(c) Based on 20 hours of exposure in the intruder-discovery scenario (see Section 4.0).

(d) Based on 2000 hours of exposure in the resource-salvage scenario (see Section 4.0).

(e) As reported for the residential/home-qarden scenario in Table 5.2.1.

(f) Based on the residential/construction scenario (see Section 4.0 ).

(g) Assuming a $1 \%$ root-penetration factor (see Section 4.0 ).

(h) Where $1.3 \mathrm{E}-1=1.3 \times 10-1$.

(i) $+D$ means plus short-lived daughter.
} 
factors from Table 5.2.1 are directly 1isted in Table 5.2.2 as unconfined soil factors. For confined soil, two conditions are considered. For contamination at depths between 1 and $4 \mathrm{~m}$ from the surface, the scenariospecific factors in Table 5.2.2 are based on the combination of the residential/construction scenario and the residential/home-garden scenario (see Section 4.0). For contamination at depths $\geq 5 \mathrm{~m}$ from the surface, the scenario-specific factors are based on the residential/home-garden scenario wi th a root penetration factor of $1 \%$.

\subsection{ALLOWABLE RESIDUAL CONTAMINATION LEVEL APPLICATIONS TO THE 1OO AREA FACILITIES}

The scenario-specific ARCL dose factors shown in Table 5.2 .2 are next applied to the representative radionuclide inventories discussed in Section 3.0 for each of the five categories of facilities considered. The representative radionuclide inventories are used to give our best current determination of ARCL values based on existing characterization data. However, we recognize that as decommissioning operations are conducted better characterization data will be generated. These data, and data from the post-decommissioning survey, should be used to determine the final ARCL values for the facilities. Thus, we have designed the ARCL methods in this report to easily accommodate changes in radionuclide mixtures and concentrations.

Scenario-specific doses for each radionuclide in the representative radionuclide inventories are shown in Tables A.1 through $A .14$ in Appendix $A$ for the restricted-, controlled-, and unrestricted-use scenarios. For restricted and controlled use, scenario-specific doses are calculated for only those categories of facilities that contain structures that could serve as safe-storage facilities. Only non-combustible and non-hazardous solid radioactive wastes are assumed to be left in safe-storage facilities that provide effective barriers to most types of intrusion. These are the retention-basin systems, nuclear reactors, and fuel-storage basins. The same procedure is followed for surface contamination in facilities for unrestricted use. Unconfined (surface) and two cases of confined (subsurface) soil contamination are considered for all five categories of 
facilities. In addition, the unrestricted-use scenario-specific ARCL doses are shown in Appendix A for decay periods of 0,100 , and 300 years.

The scenario-specific doses in Appendix $A$ are next corrected to the allowable organ dose limit by:

$$
P_{i}=\frac{D O}{\operatorname{ARCL}_{i}}\left(\pi_{j} M_{j}\right)
$$

where $P_{j}$ - the total ARCL for each radionuclide in the mixture, $\mathrm{C} i / \mathrm{m}^{2}$ or $\mathrm{pCi} / \mathrm{g}$ in soil

DO - example allowable organ dose limit of either $0.5 \mathrm{rem} / \mathrm{yr}$ for restricted and controlled use or $0.01 \mathrm{rem} / \mathrm{yr}$ for unrestricted use

$A R C L_{j}$ - the scenario-specific $A R C L$ dose for each radionuclide, $i$, in the mixture, rem/yr

$M_{j}$ - modification factors for confined soil areas. NOTE: $\pi M_{j}=1$ for surface contamination and unconfined soil calculations.

The resulting ARCL values for the 100 Area facilities are shown in:

- Table 5.3.1; for restricted use

- Table 5.3.2; for controlled use

- Table 5.3.3; for unrestricted use - surface contamination at $T=0$

- Table 5.3.4; for unrestricted use - unconfined soil (within the top $1 \mathrm{~m})$ at $T=0$

- Table 5.3.5; for unrestricted use - confined soil (at depths between 1 and $4 \mathrm{~m}$ ) at $\mathrm{T}=0$

- Table 5.3.6; for unrestricted use - confined soil (at depths $\geq 5 \mathrm{~m}$ ) at $T=0$.

The ARCL values in these tables are reported in units of disintegrations per minute (dpm) per $100 \mathrm{~cm}^{2}$ of surface or pCi/a of soil. Unrestricted use ARCL values are reported only for the first decay period 
TABLE 5.3.1. Allowable Residual Contamination Level Values for Decommissioned Facilities in the 100 Areas of the Hanford Site - Restricted Use $(a)$

\begin{tabular}{|c|c|c|c|}
\hline Radionuclide & $\begin{array}{l}\text { Retention-Basin } \\
\text { System Inventory } \\
\text { (Table } 3.1 .1) \\
(\mathrm{dpm} / 100 \mathrm{~cm}) \\
\end{array}$ & $\begin{array}{c}\text { Nuclear Reactor } \\
\text { Inventory } \\
\text { (Table } 3.4 .1) \\
\left(\mathrm{dpm} / 100 \mathrm{~cm}^{2}\right) \\
\end{array}$ & $\begin{array}{c}\text { Fuel-Storage } \\
\text { Basin Inventory } \\
(\text { Table } 3.5 .1) \\
\left(\mathrm{dpm} / 100 \mathrm{~cm}^{2}\right) \\
\end{array}$ \\
\hline${ }^{3} \mathrm{H}$ & $5.3 E+3(b)$ & $1.6 \mathrm{E}+7$ & $8.4 \mathrm{E}-4$ \\
\hline${ }^{14} \mathrm{C}$ & $1.7 \mathrm{E}+4$ & $6.6 \mathrm{E}+6$ & $-(c)$ \\
\hline${ }^{60} \mathrm{Co}$ & $2.2 E+6$ & $2.0 E+5$ & $7.6 E+5$ \\
\hline${ }^{63} \mathbf{N i}$ & $2.7 E+6$ & $2.0 E+5$ & $4.8 E+5$ \\
\hline $90 S r+d(d)$ & $5.8 E+4$ & $1.3 E+6$ & $2.9 E+5$ \\
\hline $137 \mathrm{Cs}+\mathrm{D}$ & $7.6 E+4$ & $7.3 E+4$ & $3.1 E+5$ \\
\hline $152 \mathrm{Eu}$ & $4.0 E+6$ & $1.3 E+5$ & $2.9 E+5$ \\
\hline $154 \mathrm{Eu}$ & $1.8 \mathrm{E}+6$ & $1.0 E+5$ & $2.3 E+5$ \\
\hline $238 U+D$ & $5.8 \mathrm{E}+1$ & $3.9 E+1$ & $1.4 E+2$ \\
\hline $238 \mathrm{Pu}$ & $5.4 E+2$ & $9.5 E+3$ & $6.7 E+2$ \\
\hline $239 \mathrm{Pu}$ & $1.2 \mathrm{E}+3$ & $6.1 E+3$ & $3.8 \mathrm{E}+4$ \\
\hline $241 \mathrm{Am}$ & - & $8.8 E+3$ & $=$ \\
\hline Totals & $1.1 \mathrm{E}+7$ & $2.4 E+7$ & $2.4 E+6$ \\
\hline
\end{tabular}

(a) Based on the intruder-explorer scenario (Section 4.0), the facilityspecific radionuclide inventories (Section 3.0) and an example annual dose limit of 0.5 rem.

(b) Where $5.3 E+3=5.3 \times 10^{-3}$.

(c) A dash indicates that the radionuclide shown is not considered in the radionuclide inventory shown.

(d) $+D$ means plus short-lived daughters. 
TABLE 5.3.2. Allowable Residual Contamination Level Values for Decommissioned Facilities in the 100 Areas of the Hanford Site - Controlled Use (a)

\begin{tabular}{|c|c|c|c|}
\hline Radionuclide & $\begin{array}{l}\text { Retention-Basin } \\
\text { System Inventory } \\
(\text { Table } 3.1 .1) \\
\left(\mathrm{dpm} / 100 \mathrm{~cm}^{2}\right) \\
\end{array}$ & $\begin{array}{c}\text { Nuclear Reactor } \\
\text { Inventory } \\
\text { (Table } 3.4 .1) \\
\left.\text { (dpm/100 } \mathrm{cm}^{2}\right) \\
\end{array}$ & $\begin{array}{c}\text { Fue1-Storage } \\
\text { Basin Inventory } \\
(\text { Table } 3.5 .1) \\
\left(\mathrm{dpm} / 100 \mathrm{~cm}^{2}\right) \\
\end{array}$ \\
\hline${ }^{3} \mathrm{H}$ & $2.2 E+3(b)$ & $6.5 \mathrm{E}+6$ & $3.2 E-4$ \\
\hline${ }^{14} \mathrm{C}$ & $6.9 \mathrm{E}+3$ & $2.7 E+6$ & - (c) \\
\hline${ }^{60} \mathrm{Co}$ & $9.2 E+5$ & $8.2 E+4$ & $2.9 E-5$ \\
\hline${ }^{6} \mathrm{Ni}$ & $1.1 E+6$ & $8.0 E+4$ & $1.8 \mathrm{E}+5$ \\
\hline $90 s r+D(d)$ & $2.4 E+3$ & $5.5 E+5$ & $1.1 \mathrm{E}+5$ \\
\hline $137 \mathrm{Cs}+\mathrm{D}$ & $3.1 E+4$ & $3.0 E+4$ & $1.2 E+5$ \\
\hline $152 \mathrm{Eu}$ & $1.7 E+6$ & $5.3 E+4$ & $1.1 E+5$ \\
\hline $154 \mathrm{Eu}$ & $7.3 \mathrm{E}+5$ & $4.1 E+4$ & $8.8 E+4$ \\
\hline $238 \mathrm{U}+\mathrm{D}$ & $2.4 \mathrm{E}+1$ & $1.6 \mathrm{E}-1$ & $5.5 E+1$ \\
\hline $238 \mathrm{Pu}$ & $2.2 E+2$ & $3.9 E+3$ & $2.6 \mathrm{E}+2$ \\
\hline $239 \mathrm{Pu}$ & $5.0 E+2$ & $2.5 E+3$ & $1.5 E+4$ \\
\hline $241 \mathrm{Am}$ & - & $3.6 \mathrm{E}+3$ & - \\
\hline Totals & $4.5 E+6$ & $1.0 E+7$ & $9.2 E+5$ \\
\hline
\end{tabular}

(a) Based on the intruder-discovery scenario (Section 4.0), the facilityspecific radionuclide inventories (Section 3.0 ), and an example annual dose limit of 0.5 rem.

(b) Where $2.2 E+3=2.2 \times 10^{3}$.

(c) A dash indicates that the radionuclide shown is not considered in the radionuclide inventory shown.

(d) +D means plus short-lived daughters. 
TABLE 5.3.3. Allowable Residual Contamination Level Values for Decommissioned Facilities in the 100 Areas of the Hanford Site - Unrestricted Use Surface Contamination at $T=0$ Years $(a)$

\begin{tabular}{|c|c|c|c|}
\hline Radionuclide & $\begin{array}{l}\text { Retention-Basin } \\
\text { System Inventory } \\
\text { (Table } 3.1 .1) \\
\left.\text { (dpm/100 } \mathrm{cm}^{2}\right) \\
\end{array}$ & $\begin{array}{c}\text { Nuclear Reactor } \\
\text { Inventory } \\
\text { (Table } 3.4 .1) \\
\left(\mathrm{dpm} / 100 \mathrm{~cm}^{2}\right) \\
\end{array}$ & $\begin{array}{c}\text { Fuel-Storage } \\
\text { Basin Inventory } \\
(\text { Table } 3.5 .1) \\
\left(\mathrm{dpm} / 100 \mathrm{~cm}^{2}\right) \\
\end{array}$ \\
\hline${ }^{3} \mathrm{H}$ & $3.6 \mathrm{E}-1(b)$ & $1.0 E+3$ & $5.5 \mathrm{E}-8$ \\
\hline $14 \mathrm{C}$ & $1.1 \mathrm{E}+1$ & $4.2 E+2$ & - (c) \\
\hline${ }^{60} \mathrm{Co}$ & $1.5 \mathrm{E}+2$ & $1.3 \mathrm{E}+1$ & $5.0 E+1$ \\
\hline $63 \mathrm{Ni}$ & $1.8 \mathrm{E}+2$ & $1.3 E+1$ & $3.1 E+1$ \\
\hline $90 S r+D(d)$ & $3.9 \mathrm{E}-1$ & $8.6 E+1$ & $1.9 \mathrm{E}+1$ \\
\hline $137 C s+D$ & $5.2 E+0$ & $4.7 E+0$ & $2.0 E+1$ \\
\hline $152 \mathrm{Eu}$ & $2.7 E+2$ & $8.3 E+0$ & $1.9 \mathrm{E}+1$ \\
\hline $154 \mathrm{Eu}$ & $1.2 \mathrm{E}+2$ & $6.4 E+0$ & $1.5 \mathrm{E}+1$ \\
\hline $238 \mathrm{U}+\mathrm{D}$ & $3.9 E-3$ & $2.5 \mathrm{E}-5$ & $9.4 \mathrm{E}-3$ \\
\hline $\begin{array}{l}238 \mathrm{Pu} \\
239 \mathrm{Pu}\end{array}$ & $\begin{array}{l}3.7 \mathrm{E}-2 \\
8.3 \mathrm{E}-2\end{array}$ & $\begin{array}{l}6.3 \mathrm{E}-1 \\
3.9 \mathrm{E}-1\end{array}$ & $\begin{array}{l}4.4 E-2 \\
2.5 E+0\end{array}$ \\
\hline $241 \mathrm{Am}$ & $\begin{array}{r}0.0-6 \\
- \\
\end{array}$ & $5.7 \mathrm{E}-1$ & - \\
\hline Totals & $7.5 E+2$ & $1.6 E+3$ & $1.6 E+2$ \\
\hline
\end{tabular}

(a) Based on the resource salvage and resource-recycle scenarios (Section 4.0 ), the facility-specific radionuclide inventories (Section 3.0 ) and an example annual dose limit of $0.01 \mathrm{rem}$.

(b) Where $3.6 \mathrm{E}-1=3.6 \times 10^{-1}$.

(c) A dash indicates that the radionuclide shown is not considered in the radionuclide inventory shown.

(d) $+D$ means plus short-lived daughters. 

TABLE 5.3.4. Allowable Residual Contamination Level Values for Decommissioned Facilities jn
the 100 Areas of the Hanford Site - Unconfined Surface Soil at $T=0$ Years

\begin{tabular}{|c|c|c|c|c|c|}
\hline Radionuclide & $\begin{array}{c}\text { Retention Basin } \\
\text { System Inventory } \\
\text { (Table } 3.1 .1) \\
(\mathrm{pC} \mathrm{i} / \mathrm{g}) \\
\end{array}$ & $\begin{array}{l}\text { Miscellaneous } \\
\text { Cribs and } \\
\text { Trenches Inventory } \\
\text { (Table } 3.2 .2) \\
(\mathrm{pCi} / \mathrm{g}) \\
\end{array}$ & $\begin{array}{l}\text { Solid Waste } \\
\text { Burial Grounds } \\
\text { Inventory } \\
\text { (Table } 3.3 .2) \\
(\mathrm{pC} i / \mathrm{g}) \\
\end{array}$ & $\begin{array}{c}\text { Nuclear } \\
\text { Inventory } \\
\text { (Table } 3.4 .1) \\
(\mathrm{pC} i / \mathrm{g}) \\
\end{array}$ & $\begin{array}{c}\text { Fuel-Storage } \\
\text { Basin Inventory } \\
\text { (Table } 3.5 .1) \\
\text { (pCi/g) }\end{array}$ \\
\hline $\begin{array}{l}{ }^{3} \mathrm{H} \\
{ }^{14} \mathrm{C} \\
{ }^{60} \mathrm{Co}\end{array}$ & $\begin{array}{l}1.7 E-3(b) \\
5.2 E-3 \\
6.9 E-1\end{array}$ & $\begin{array}{l}8.6 \mathrm{E}-3 \\
1.6 \mathrm{E}-1 \\
1.6 \mathrm{E}-1\end{array}$ & $\begin{array}{l}-(c) \\
- \\
7.6 \mathrm{E}-1\end{array}$ & $\begin{array}{l}1.0 E+0 \\
4.4 E-1 \\
1.3 E-2\end{array}$ & $\begin{array}{c}1.9 \mathrm{E}-10 \\
- \\
1.8 \bar{E}-1\end{array}$ \\
\hline $\begin{array}{l}{ }^{63} \mathrm{Ni} \\
90 \mathrm{Sr+D}(\mathrm{d}) \\
137 \mathrm{Cs}+\mathrm{D}\end{array}$ & $\begin{array}{l}\text { 8. } 3 E-1 \\
\text { i. } 8 E-3 \\
2.3 E-2\end{array}$ & $\begin{array}{c}- \\
6.1 E-2 \\
2.4 E-1\end{array}$ & $\begin{array}{l}7.2 E-3 \\
1.3 E-2 \\
1.0 E-2\end{array}$ & $\begin{array}{l}1.3 E-2 \\
8.9 E-2 \\
4.8 E-3\end{array}$ & $\begin{array}{l}1.1 E-1 \\
6.7 E-2 \\
7.2 E-2\end{array}$ \\
\hline $\begin{array}{l}152 \mathrm{Eu} \\
154 \mathrm{Eu} \\
238 \mathrm{U}+\mathrm{D}\end{array}$ & $\begin{array}{l}1.2 E-0 \\
5.5 E-1 \\
1.8 E-5\end{array}$ & $\begin{array}{l}8.6 E-2 \\
2.6 E-3 \\
5.6 E-5\end{array}$ & $\begin{array}{l}7.7 \mathrm{E}-2 \\
3.5 \mathrm{E}-2 \\
1.5 \mathrm{E}-5\end{array}$ & $\begin{array}{l}8.6 E-3 \\
6.6 E-3 \\
2.6 E-8\end{array}$ & $\begin{array}{l}6.7 E-2 \\
5.3 E-2 \\
3.3 E-5\end{array}$ \\
\hline $\begin{array}{l}238 \mathrm{Pu} \\
239 \mathrm{Pu} \\
241 \mathrm{Am}\end{array}$ & $\begin{array}{c}1.7 E-4 \\
3.8 E-4 \\
-\end{array}$ & $\begin{array}{c}6.5 E-5 \\
4.8 E-3 \\
-\end{array}$ & $\begin{array}{c}- \\
9.2 E-5 \\
-\end{array}$ & $\begin{array}{l}6.3 E-4 \\
4.0 E-4 \\
5.8 E-4\end{array}$ & $\begin{array}{c}1.6 E-4 \\
8.9 E-3 \\
-\end{array}$ \\
\hline Totals & $3.4 E+0$ & $7.2 \mathrm{E}-1$ & $8.9 E-1$ & $1.6 E+0$ & $5.6 \mathrm{E}-1$ \\
\hline
\end{tabular}

(a) Based on the residential/home-garden scenario (Section 4.0 ), the radionuclide inventories for each facility (Section 3.0), and an annual dose limit of 0.01 rem.

(b) Where $1.7 \mathrm{E}-3=1.7 \times 10^{-3}$.

(c) A dash indicates that the radionuclide shown is not considered in the radionuclide inventory shown.

(d) $+D$ means plus short-lived daughters. 
TABLE 5.3.5. Allowable Residual Contamination Level Values for Decommissioned Facilities in the 100 Areas of the Hanford Site $j$ Unrestricted Use Confined Soil at Depths Between 1 and $4 \mathrm{~m}$ at $T=0$ Years $(\mathrm{a})$

\begin{tabular}{|c|c|c|c|c|c|}
\hline Radionuclide & $\begin{array}{c}\text { Retention Basin } \\
\text { System Inventory } \\
\text { (Table } 3.1 .1) \\
(\mathrm{pC} i / \mathrm{g}) \\
\end{array}$ & $\begin{array}{c}\text { Miscellaneous } \\
\text { Cribs and } \\
\text { Trenches Inventory } \\
\text { (Table } 3.2 .2 \text { ) } \\
\text { (pCi/g) } \\
\end{array}$ & $\begin{array}{l}\text { Solid Waste } \\
\text { Burial Grounds } \\
\text { Inventory } \\
\text { (Table 3.3.2) } \\
(\mathrm{pC} i / g) \\
\end{array}$ & $\begin{array}{c}\text { Nuclear } \\
\text { Inventory } \\
\text { (Table } 3.4 .1) \\
(\mathrm{pC} \mathrm{i} / \mathrm{g}) \\
\end{array}$ & $\begin{array}{c}\text { Fuel-Storage } \\
\text { Basin Inventory } \\
\text { (Table } 3.5 .1) \\
\text { (pCi } / \mathrm{g}) \\
\end{array}$ \\
\hline $\begin{array}{l}{ }^{3} \mathrm{H} \\
{ }^{14} \mathrm{C} \\
{ }^{60} \mathrm{Co}\end{array}$ & $\begin{array}{l}8.3 E-3(b) \\
2.6 E-2 \\
3.4 E+0\end{array}$ & $\begin{array}{l}4.3 E-2 \\
7.9 E-1 \\
7.9 E-1\end{array}$ & $\begin{array}{l}-(c) \\
- \\
3.8 E+0\end{array}$ & $\begin{array}{l}5.0 E+0 \\
2.2 E+0 \\
6.5 E-2\end{array}$ & $\begin{array}{c}9.2 \mathrm{E}-10 \\
- \\
8.4 \mathrm{E}-1\end{array}$ \\
\hline $\begin{array}{l}{ }^{63} \mathrm{Ni} \\
90 \mathrm{Sr}+\mathrm{D}(\mathrm{d}) \\
137 \mathrm{Cs}+\mathrm{D}\end{array}$ & $\begin{array}{l}4.1 E+0 \\
9.0 E-3 \\
1.2 E-1\end{array}$ & $\begin{array}{c}-\overline{-} \\
3.0 E-1 \\
1.1 E+0\end{array}$ & $\begin{array}{l}3.6 \mathrm{E}-2 \\
6.5 \mathrm{E}-2 \\
5.0 \mathrm{E}-2\end{array}$ & $\begin{array}{l}6.5 E-2 \\
4.4 E-1 \\
2.4 E-3\end{array}$ & $\begin{array}{l}5.1 E-1 \\
3.2 E-1 \\
3.3 E-1\end{array}$ \\
\hline $\begin{array}{l}152 \mathrm{Eu} \\
154 \mathrm{EU} \\
238 \mathrm{U}+\mathrm{D}\end{array}$ & $\begin{array}{l}6.2 E+0 \\
2.8 E+0 \\
9.0 E-5\end{array}$ & $\begin{array}{l}4.3 E-1 \\
1.3 E-2 \\
2.8 E-4\end{array}$ & $\begin{array}{l}3.8 E-1 \\
1.8 E-1 \\
7.5 E-5\end{array}$ & $\begin{array}{l}4.3 E-2 \\
3.3 E-2 \\
1.3 E-7\end{array}$ & $\begin{array}{l}3.2 E-1 \\
2.4 E-1 \\
1.5 E-4\end{array}$ \\
\hline $\begin{array}{l}238 \mathrm{Pu} \\
239 \mathrm{Pu} \\
241 \mathrm{Am}\end{array}$ & $\begin{array}{c}8.4 E-4 \\
1.9 E-3 \\
-\end{array}$ & $\begin{array}{c}3.2 E-4 \\
2.4 E-2 \\
-\end{array}$ & $\begin{array}{c}- \\
4.6 E-4 \\
-\end{array}$ & $\begin{array}{l}3.2 E-5 \\
6.9 E-3 \\
2.9 E-3\end{array}$ & $\begin{array}{c}7.4 E-4 \\
4.1 E-2 \\
-\end{array}$ \\
\hline Totals & $1.7 \mathrm{E}+1$ & $3.5 \mathrm{E}+0$ & $4.5 E+0$ & $7.9 E+0$ & $2.6 E+0$ \\
\hline
\end{tabular}

(a) Based on the residential/construction and residential/home-garden scenarios (Section 4.0), the radionuclide inventories for each facility (Section 3.0), and an annual dose limit of 0.01 rem.

(b) Where $8.3 \mathrm{E}-3=8.3 \times 10^{-3}$.

(c) A dash indicates that the radionuclide shown is not considered in the radionuclide inventory shown.

(d) $+D$ means plus short-lived daughters. 
TABLE 5.3.6. ARCL Values for Decommissioned Facilities in the 100 Areas of the Hanford Site Unrestricted Use Confined Soil at Depths $\geq 5 \mathrm{~m}$ at $T=0$ Years $(\mathrm{a})$

\begin{tabular}{|c|c|c|c|c|c|}
\hline Radionuclide & $\begin{array}{l}\text { Retention Basin } \\
\text { System Inventory } \\
\text { (Table } 3.1 .1) \\
(\mathrm{pC} \mathrm{i} / \mathrm{g}) \\
\end{array}$ & $\begin{array}{c}\text { Miscellaneous } \\
\text { Cribs and } \\
\text { Trenches Inventory } \\
\text { (Table } 3.2 .2) \\
(\mathrm{pCi} / \mathrm{g}) \\
\end{array}$ & $\begin{array}{l}\text { Solid Waste } \\
\text { Burial Grounds } \\
\text { Inventory } \\
\text { (Table } 3.3 .2) \\
(\mathrm{pCi} / \mathrm{g}) \\
\end{array}$ & $\begin{array}{c}\text { Nuclear } \\
\text { Inventory } \\
\text { (Table } 3.4 .1) \\
(\mathrm{pCi} / \mathrm{g}) \\
\end{array}$ & $\begin{array}{c}\text { Fuel-Storage } \\
\text { Basin Inventory } \\
\text { (Table } 3.5 .1) \\
(\mathrm{pCi} / \mathrm{q}) \\
\end{array}$ \\
\hline${ }^{3} \mathrm{H}$ & $2.7 E+0(b)$ & $1.3 E+0$ & $-(c)$ & $1.1 E+2$ & $2.7 E-8$ \\
\hline${ }^{14} \mathrm{C}$ & $8.3 E+0$ & $2.3 E+1$ & - & $4.5 \mathrm{E}+1$ & - \\
\hline${ }^{60} \mathrm{Co}$ & $1.1 E+3$ & $2.3 E+1$ & $5.1 \mathrm{E}+2$ & $1.4 \mathrm{E}+0$ & $2.5 \mathrm{E}+1$ \\
\hline${ }^{63} \mathrm{Ni}$ & $1.3 E+3$ & - & $4.8 E+0$ & $1.3 E+0$ & $1.5 \mathrm{E}+1$ \\
\hline${ }^{90} S r+D(d)$ & $2.9 E+0$ & $9.0 \mathrm{E}+0$ & $8.9 E+0$ & $8.7 E+0$ & $9.2 E+0$ \\
\hline $137 \mathrm{Cs}+\mathrm{D}$ & $3.8 E+1$ & $3.5 E+1$ & $7.2 E+0$ & $5.0 \mathrm{E}-1$ & $1.0 \mathrm{E}+1$ \\
\hline $152 \mathrm{Eu}$ & $2.0 E+3$ & $1.3 E+1$ & $5.1 E+1$ & $8.8 \mathrm{E}-1$ & $9.2 \mathrm{E}+0$ \\
\hline${ }^{154} \mathrm{Eu}$ & $8.9 E+2$ & $3.9 E-1$ & $2.3 E+1$ & $6.8 \mathrm{E}-1$ & $7.4 E+0$ \\
\hline $238 U+D$ & $2.9 \mathrm{E}-2$ & $8.4 E-3$ & $1.0 E-2$ & $2.7 \mathrm{E}-6$ & $4.6 \mathrm{E}-3$ \\
\hline $238 \mathrm{Pu}$ & $2.7 E-1$ & $9.6 \mathrm{E}-3$ & - & $6.5 \mathrm{E}-2$ & $2.2 E-2$ \\
\hline $239 \mathrm{Pu}$ & $6.1 E-1$ & $7.1 \mathrm{E}-1$ & $6.1 E-2$ & $4.2 E-2$ & $1.2 \mathrm{E}+0$ \\
\hline $241 \mathrm{Am}$ & - & - & - & $6.0 E-2$ & - \\
\hline Totals & $5.7 E+3$ & $1.0 \mathrm{E}+2$ & $6.0 E+2$ & $1.7 E+2$ & $7.7 \mathrm{E}+1$ \\
\hline
\end{tabular}

(a) Based on the residential/home-garden scenario with a root penetration factor of $1 \%$ (Section 4.0 ), the radionuclide inventories for each facility (Section 3.0), and an annual dose 1 imit of 0.01 rem.

(b) Where $2.7 \mathrm{E}+0=2.7 \times 10^{0}$.

(c) A dash indicates that the radionuclide shown is not considered in the radionuclide inventory shown.

(d) $+D$ means plus short-lived daughters. 
$(T=0)$ in this section. Listings of the ARCL values for the other two decay periods ( $T=100$ and $T=300$ years) are included in Appendix $A$ in Tables A.15 through A.22. The ARCL values reported for $T=300$ and $T=100$ years represent the levels that would have to be reached by radioactive decay or decontamination if materials in safe storage are to achieve an unrestricted release.

A description of how to modify the ARCL values to accommodate changes in the radionuclide mixture or the assumed maximum annual dose 1 imit is given in Appendix B. Appendix B also contains a worksheet for performing the calculations and includes sample problems. To determine the effect of radioactive decay on the $A R C L$ value calculated for a mixture, a radioactive decay correction should be applied to the source inventory. This correction is outlined in a second worksheet described in Appendix B. The decay correction calculation is intended to help define levels that will require no additional decontamination beyond radioactive decay for periods of safestorage during restricted or controlled use.

\subsection{SUMMARY OF RESULTS}

Summaries of the ARCL method results are shown in Table 5.4.1 for surface contamination and in Table 5.4.2 for soil contamination for the 100 Area facilities at the Hanford Site. The values are shown in units of $\mathrm{dpm} / 100 \mathrm{~cm}^{2}$ for surface contamination and $\mathrm{pCi} / \mathrm{g}$ for soil contamination. Dominant radionuclide contributors to the annual dose within the representative radionuclide mixtures are also identified in these tables.

For surface contamination wi thin facilities (see Table 5.4.1), ARCL values are shown for the retention-basin system, nuclear reactors, and fuel-storage basins. Restricted use ARCL values range from $2.4 \times 10^{6}$ to $2.4 \times 107 \mathrm{dpm} / 100 \mathrm{~cm}^{2}$. Control led use ARCL values range from $9.2 \times 105$ to $1 \times 10^{7} \mathrm{dpm} / 100 \mathrm{~cm}^{2}$. These ranges reflect the dose potential of the facility-specific radionuclide inventories (described in Section 3.0). For unrestricted use, the ARCL values generally increase with time from $T=0$ to $T=300$ years for each facility. For example, the ARCL value for the retention-basin systems at time $T=0$ years is $750 \mathrm{dpm} / 100 \mathrm{~cm}^{2}$ and is 


\section{TABLE 5.4.1. Summary of the Allowable Residual Contamination Level Values for Surface Contamination in Decommissioned Facilities in the 100 Areas of the Hanford Site}

\begin{tabular}{|c|c|c|c|c|c|c|}
\hline \multirow[b]{2}{*}{ Use Mode } & \multicolumn{2}{|c|}{ RETENTION BASIN SYSTEM } & \multicolumn{2}{|c|}{ MUU,LEAR REACTIRS } & \multicolumn{2}{|c|}{ FUEL STORAGE BASINS } \\
\hline & ARCL $\left(\mathrm{dpm} / 100 \mathrm{~cm}^{2}\right)$ & $\begin{array}{c}\text { Dominant } \\
\text { Radionuclides } \\
\end{array}$ & ARCL $\left(\mathrm{dpm} / 100 \mathrm{~cm}^{2}\right)$ & $\begin{array}{c}\text { Dominant } \\
\text { Radionuclides }\end{array}$ & ARCL $\left(\mathrm{dpm} / 100 \mathrm{~cm}^{2}\right)$ & $\begin{array}{c}\text { Dominant } \\
\text { Radionuclides } \\
\end{array}$ \\
\hline Restricted Use & $1.1 E+7(a)$ & $60 \mathrm{Co}, 152 \mathrm{Eu}$ & $2.4 E+7$ & $90 \mathrm{Sr}+\mathrm{D}(\mathrm{b}), 241 \mathrm{Am}$ & $2.4 \mathrm{E}+6$ & $239 \mathrm{Pu}, 90 \mathrm{sr}+\mathrm{D}$ \\
\hline Controlled Use & $4.5 E+6$ & ${ }^{60} \mathrm{Co}, 152 \mathrm{Eu}$ & $1.0 \mathrm{E}+7$ & $90 \mathrm{Sr}+0,241_{\mathrm{Am}}$ & $9.2 E+5$ & $239 \mathrm{pu}, 90 s r+0$ \\
\hline \multicolumn{7}{|l|}{ Unrestricted Use (c) } \\
\hline - at $T=0$ years & $7.5 E+2$ & $60 \mathrm{co}, 152 \mathrm{~F}_{11}$ & $1.6 \mathrm{E}+3$ & ${ }^{90} \mathrm{Sr+D}, 241_{\mathrm{Am}}$ & 1. $5 E+?$ & $23^{9} \mathrm{Pu}, 90 \mathrm{sr}+1$ \\
\hline - at $T=100$ years & $1.7 \mathrm{E}+4$ & $239 \mathrm{Pu}, 63 \mathrm{Ni}$ & $3.1 E+3$ & $241_{\mathrm{Am}}, 238 \mathrm{Pu}$ & $2.2 E+2$ & $239 \mathrm{Pu}, 90 \mathrm{sr}+0$ \\
\hline - at $T=300$ years & $2.6 E+4$ & $239 \mathrm{Pu}, 63 \mathrm{Ni}$ & $5.8 E+3$ & $241_{4 m}, 239 \mathrm{pu}$ & $2.2 E+2$ & $239 \mathrm{p} u, 238 u+D$ \\
\hline
\end{tabular}

(a) Where $1.1 \mathrm{E}+7=1.1 \times 10^{7}$.

(b) $+D$ means plus short-lived daughters.

(c) Three decay periods are considered for unrestricted use. Thev are: $T=0, T=100$, and $T=30 n$ years. 
control led by direct exposure from 60Co and 152Eu. However, since both of these radionuclides have relatively short half-lives, the ARCL values at $T=100$ and $T=300$ years are controlled by $239 \mathrm{Pu}$ through internal exposure (i.e., inhalation and ingestion) pathways. The result of the change in the radionuclide mixture, because of radioactive decay, is that the retentionbasin system ARCL increases to $2.6 \times 104 \mathrm{dpm} / 100 \mathrm{~cm} 2$ at 300 years. Again, the ARCL values reported for $T=100$ and $T=300$ years represent the levels that would have to be reached by radioactive decay (or decontamination) if materials in safe storage are to achieve an unrestricted release.

A summary of the ARCL values for soil contamination is shown in Table 5.4.2. This table contains the ARCL values calculated for all five categories of facilities, for the three decay periods, and for unconfined (surface) and two conditions of confined (subsurface) soil. The ARCL values generally increase with time from $T=0$ to $T=300$, reflecting the radioactive decay of the more biologically available radionuclides in the representative mixtures. The ARCL values also increase with depth from surface soils to soils at depths greater than or equal to $5 \mathrm{~m}$. For example, the solid waste burial ground ARCL values increase by one to two orders of magnitude from both surface soil to depths between 1 and $4 \mathrm{~m}$, and from depths of 1 to $4 \mathrm{~m}$ to depths greater than or equal to $5 \mathrm{~m}$ for all decay times. It should be noted that the alpha emitting radionuclides (i.e., $238 \mathrm{U}, 238 \mathrm{Pu}, 239 \mathrm{Pu}$, and $241_{\mathrm{Am}}$ ) in the mixtures are never the dominant radionuclides for the soil contamination conditions. This is because the doses are controlled by ingestion of fruit and vegetable crops grown in the contaminated soil, and not by inhalation of resuspended radionuclides. The results of the ARCL calculations for facilities in the 100 Areas of the Hanford Site are more fully discussed in the following section. 
TABLE 5.4.2. Summary of the Allowable Residual Contamination Level Soil Contamination Values for Decommissioning Facilities in the 100 Areas of the Hanford Site

ARCL and Controlling Radionuclide for Selected Times in the Future

\begin{tabular}{|c|c|c|c|c|c|c|}
\hline \multirow[b]{3}{*}{ Facility Category/Soil Condition(a) } & \multicolumn{6}{|c|}{ ARCL and Controlling Radionuclide for Selected Times in the Future } \\
\hline & \multicolumn{2}{|c|}{$T=0$ Years } & \multicolumn{2}{|c|}{$T=100$ Years } & \multicolumn{2}{|c|}{$T=300$ Years } \\
\hline & ARCL $(p C i / g)$ & $\begin{array}{l}\text { Dominant }(b) \\
\text { Radionuclide }\end{array}$ & ARCL $(b C i / q)$ & $\begin{array}{l}\text { Dominant }(b) \\
\text { Radionuclide }\end{array}$ & $\underline{A R C L}(\mathrm{pC} i / g)$ & $\begin{array}{l}\text { Dominant (b) } \\
\text { Radinnuclide }\end{array}$ \\
\hline $\begin{array}{l}\text { Retention Basin Systems } \\
\text { - Unconfined Soil } \\
\text { - Confined Soil (1-4 m deep) } \\
\text { - Confined Soil ( } 25 \mathrm{~m} \text { deep) }\end{array}$ & $\begin{array}{l}3.4 E+0(C) \\
1.7 E+1 \\
5.3 E+3\end{array}$ & $\begin{array}{r}152 \mathrm{Eu} \\
152 \mathrm{Eu} \\
63 \mathrm{Ni}\end{array}$ & $\begin{array}{l}4.4 \mathrm{E}+1 \\
6.2 \mathrm{E}+2 \\
1.5 \mathrm{E}+4\end{array}$ & $\begin{array}{l}63 \mathrm{Ni} \\
63 \mathrm{Ni} \\
63 \mathrm{Ni}\end{array}$ & $\begin{array}{l}6.2 E+2 \\
3.2 E+3 \\
6.6 E+4\end{array}$ & $\begin{array}{l}63 \mathrm{Ni} \\
63 \mathrm{Ni} \\
63 \mathrm{Ni}\end{array}$ \\
\hline $\begin{array}{l}\text { Miscellaneous Cribs and Trenches } \\
\text { - Unconfined Soil } \\
\text { - Confined Soil }(1-4 \mathrm{~m} \text { deep) } \\
\text { - Confined Soil ( } \geq 5 \mathrm{~m} \text { deep) }\end{array}$ & $\begin{array}{l}7.2 \mathrm{E}-1 \\
3.5 \mathrm{E}+0 \\
1.0 \mathrm{E}+2\end{array}$ & $\begin{array}{l}90 S r+D(d) \\
90 s r+D \\
90 s r+D\end{array}$ & $\begin{array}{l}1.3 E+0 \\
5.5 E+1 \\
1.3 E+3\end{array}$ & $\begin{array}{l}90 S r+D \\
90 S r+D \\
90 S r+D\end{array}$ & $\begin{array}{l}1.6 E+3 \\
6.8 E+3 \\
2.1 E+5\end{array}$ & $\begin{array}{l}90 S r+D \\
90 S r+D \\
90 S r+D\end{array}$ \\
\hline $\begin{array}{l}\text { Solid Waste Burial Grounds } \\
\text { - Unconfined Soil } \\
\text { - Confined Soil }(1-4 \mathrm{~m} \text { deed }) \\
\text { - Confined Soil }(\geq 5 \mathrm{~m} \text { deep })\end{array}$ & $\begin{array}{l}8.9 E-1 \\
4.5 E+0 \\
6.0 E+2\end{array}$ & $\begin{array}{l}60 \mathrm{Co} \\
60 \mathrm{Co} \\
90 \mathrm{Sr+D}\end{array}$ & $\begin{array}{l}2.4 E+1 \\
3.4 E+2 \\
7.1 E+3\end{array}$ & $\begin{array}{l}90 S r+D \\
90 S r+D \\
90 S r+D\end{array}$ & $\begin{array}{l}6.4 E+3 \\
3.0 E+4 \\
6.5 E+5\end{array}$ & $\begin{array}{l}90 S r+D \\
90 S r+D \\
90 S r+D\end{array}$ \\
\hline $\begin{array}{l}\text { Nuclear Reactors } \\
\text { - Unconfined Soil } \\
\text { - Confined Soil }(1-4 \mathrm{~m} \text { deep) } \\
\text { - Confined Soil ( } 2 \mathrm{~m} \text { deep })\end{array}$ & $\begin{array}{l}1.6 \mathrm{E}+0 \\
7.9 \mathrm{E}+0 \\
1.7 \mathrm{E}+2\end{array}$ & $\begin{array}{l}90 S r+D \\
90 S r+D \\
90 S r+D\end{array}$ & $\begin{array}{l}1.8 E+1 \\
9.9 E+1 \\
2.0 E+3\end{array}$ & $\begin{array}{l}90 S r+0 \\
90 S r+D \\
90 S r+D\end{array}$ & $\begin{array}{l}2.7 F+3 \\
1.4 E+4 \\
2.7 E+5\end{array}$ & $\begin{array}{l}90 S r+D \\
90 S r+D \\
90 S r+1\end{array}$ \\
\hline $\begin{array}{l}\text { Fuel Storage Basins } \\
\text { - Unconfined Soil } \\
\text { - Confined Soil (1-4 m deep) } \\
\text { - Confined Soil (>5 m deep) }\end{array}$ & $\begin{array}{l}5.6 \mathrm{E}-1 \\
2.6 \mathrm{E}+0 \\
7.7 \mathrm{E}+1\end{array}$ & $\begin{array}{l}90 s r+D \\
90 s r+D \\
90 s r+D\end{array}$ & $\begin{array}{l}2.6 E+0 \\
3.2 E+1 \\
9.1 E+2\end{array}$ & $\begin{array}{l}90 S r+0 \\
90 S r+D \\
90 S r+D\end{array}$ & $\begin{array}{l}4.6 E+2 \\
2.0 E+3 \\
5.3 E+4\end{array}$ & $\begin{array}{l}63 \mathrm{Ni} \\
63 \mathrm{Ni} \\
63 \mathrm{Ni}\end{array}$ \\
\hline
\end{tabular}

(a) Three soil conditions are considered: unconfined surface soil (to a depth of $1 \mathrm{~m}$ ), confined soil at depths between 1 and $4 \mathrm{~m}$, and confined soil at depths $\geq 5 \mathrm{~m}$.

(b) The dominant radionuclide shown is the one that results in the largest scenario-specific dose, as shown in Tables $A .1$ through A.14 in Appexdix A.

(c) Where $3.4 \mathrm{E}+0=3.4 \times 10^{0}$.

(d) $+D$ means plus short-lived daughters. 


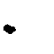




\subsection{DISCUSSION OF RESULTS}

The Allowable Residual Contamination Levels (ARCL) reported in this document, for the five generic categories of facilities in the 100 Areas of the Hanford Site, are based on a scenario/exposure-pathway analysis and compliance with an annual dose limit. ARCL values are presented for three modes of future use of the land and facilities. The modes are restricted use, control led use, and unrestricted use. Information on restricted and controlled use is included to provide engineers with a broad data base for considering decommissioning alternatives. This data base should help engineers conduct a full decommissioning safety and cost analysis for the Hanford production reactors and associated facilities.

Procedures for modifying the ARCL values to accommodate changes in radionuclide mixtures or annual dose limits are described in the previous section (see Section 5.3), and a worksheet method is discussed in Appendix B. We have based our calculations on example annual dose limits of $500 \mathrm{mrem} / \mathrm{yr}$ for restricted and controlled use and $10 \mathrm{mrem} / \mathrm{yr}$ for unrestricted use since there are presently no DOE guidelines for acceptable dose limits specific to decommissioning. The example annual dose limits are used to help demonstrate the ARCL method only.

In this section, further modifications to the basic ARCL values and the key modeling assumptions are described, along with a comparison to existing NRC guidelines for decommissioning (U.S. AEC 1974) and low-level waste disposal (U.S. NRC 1982). This section al so contains a discussion of our overall conclusions.

\subsection{KEY ASSUMPTIONS}

The surface contamination ARCL values, presented for the representative radionuclide mixtures, are based on removable contamination only. This as sumption was made to account for the uncertainties associated with the behavior of "fixed" contamination over long time periods. However, if it can be shown that part of the surface contamination will remain fixed, the resultant $A R C L$ values will increase since less material will be 
available for resuspension or transfer to the hands for direct ingestion. As an example, we repeated part of the analysis presented in Section 5.0 using the representative mixture of radionuclides for the restricted-use mode assuming that only $10 \%$ of the contamination was removable, with $90 \%$ fixed. The results showed an increase in the ARCL value by about a factor of 6 compared to the values reported for the facilities in this report.

The unrestricted-use calculations, for surface contamination in the facilities, were based on the resource-salvage scenario. In this scenario, we assumed that both the surfaces of the facility and the internal surfaces of piping and equipment had the same contamination level. This may be unreasonable if decontamination of the inside surfaces of piping and equipment proves to be difficult or inaffective. Modifications to the basic ARCL calculations can be made to account for higher internal surface contamination levels by increasing the air concentration that results from cutting operations. As an example, we repeated the calculation assuming that the inside surfaces of piping and equipment were ten times more contaminated than building surfaces at $T=0$. The impact of this change is to increase the air concentration resulting from cutting operations by a factor of 10. This will reduce the ARCL values calculated in this report by about a factor of 3 .

In this study we considered surface contamination in facilities and soil contamination only. In practice, material containing surface contamination may be left buried in the soil at a site. Thus, a method is needed to convert surface contamination levels to volume contamination levels for comparison with the ARCL values for soil. This can be done by using the radiological survey data (in $\mathrm{dpm} / 100 \mathrm{~cm}^{2}$ or $\mathrm{Ci} / \mathrm{m}^{2}$ ), an estimate of total contaminated surface area $\left(\mathrm{cm}^{2}\right.$ or $\left.\mathrm{m}^{2}\right)$, and engineering data about the volume and mass of rubble to be buried. For example, consider the surface contamination associated with a wall in a building. The contamination level times the total contaminated surface area of the wall will give an estimate of the total $\mathrm{C} i$ of contamination present. This value, divided by the approximate mass of the wall, can be used to give a $\mathrm{pCi} / \mathrm{g}$ estimate which can be directly compared to the unconfined or confined soil ARCL 
values. This method does not account for further dilution of the radionuclides in soil and it assumes homogeneous mixing with all materials in the wal1; however, it does provide a working estimate of the potential concentrations of material to be buried.

\subsection{MODELING ASSUMPTIONS}

Several key assumptions were made in the calculation of the scenariospecific ARCL dose conversion factors. These assumptions included:

- the particle size distribution of airborne radionuclides

- the air concentrations resulting from resuspension and cutting operations

- the solubility of inhaled radionuclides in the bloodstream

- the uniform distribution of soil contamination in the top meter of soil

- the chemical availability of the radionuclides in the soil permitting root uptake

- the exposure durations and diet of the exposed individual

- the quantity of material assumed to be salvaged in the resourcesalvage scenario

- the root uptake model assumed for $14 \mathrm{C}$.

We have attempted to be consistent in making these assumptions by using either Hanford-specific data (where available) or "standard" values used in previous modeling assessments.

Perhaps the modeling assumption with the largest potential impact on the results is the root uptake factor assumption used for ${ }^{14} \mathrm{C}$. Current models for ${ }^{14} \mathrm{C}$ are focused on the equilibrium incorporation of $\mathrm{CO}_{2}$ gas into growing plant materials. Because the ${ }^{14} \mathrm{C}$ of concern in this analysis is in a solid graphite form, we felt that the simple equilibrium model was not adequate for potential soil contamination. We, therefore, applied a standard root uptake model, as described in the FOOD computer program (Napier et al. 1980), with an assumed root uptake factor of $2.5 \times 10^{-4}$. 
This approach recognizes the long-term potential for an increased availability of the ${ }^{14} \mathrm{C}$ from the solid graphite form.

\subsection{COMPARISONS WITH EXISTING GUIDANCE}

The U.S. Nuclear Regulatory Commission (NRC) has provided guidance for the termination of 1 icenses for nuclear reactors in Regulatory Guide 1.86 (U.S. AEC 1974) and the land disposal of radioactive wastes (U.S. NRC 1982). We conducted a comparison of the ARCL values for specific radionuclides with the values reported for removable surface contamination in Table I of Regulatory Guide 1.86 and with land disposal requirements in 10 CFR Part 61. The results of these comparisons are shown in Table 6.3.1.

The comparison between our ARCL values and those in Regulatory Guide 1.86 showed generally good agreement for most radionuclides. For $137 \mathrm{Cs}$, we calculate an ARCL value for removable surface contamination of about 5000 $\mathrm{dpm} / 100 \mathrm{~cm}^{2}$, which is a factor of five greater than the value reported by the NRC $\left(1000 \mathrm{dpm} / 100 \mathrm{~cm}^{2}\right)$. For $60 \mathrm{Co}$, our ARCL value is a factor of 2.5 lower than the NRC value, and for $90 \mathrm{Sr}$ our value equals the NRC value. The major differences are for ${ }^{14} \mathrm{C}$ and ${ }^{238} U+D$. Our value for ${ }^{14} \mathrm{C}$ is 180,000 $\mathrm{dpm} / 100 \mathrm{~cm}^{2}$, which is much higher than the $5000 \mathrm{dpm} / 100 \mathrm{~cm}^{2}$ reported by the NRC. Our value for $238 \mathrm{U}+\mathrm{D}$ is only $4 \mathrm{dpm} / 100 \mathrm{~cm}^{2}$, which is much lower than the $1000 \mathrm{dpm} / 100 \mathrm{~cm}^{2}$ reported by the NRC. These differences result from the pathway-specific analysis that we performed for each radionuclide based on $10 \mathrm{mrem} / \mathrm{yr}$ compared to the four administrative limits identified by the NRC for broad categories of radionuclides.

We next compared our confined soil ARCL values (at depths between 1 and $4 \mathrm{~m}$ ) with the values reported by the NRC for land disposal of radioactive wastes (U.S. NRC 1982). In doing this, we recognize that our calculations were not intended to model licensed low-level waste burial sites since we assumed an annual dose limit of $10 \mathrm{mrem} / \mathrm{yr}$, and not $500 \mathrm{mrem} / \mathrm{yr}$ as defined by the NRC (1982). In addition, our analysis considered soil contamination only, without taking credit for waste package or waste form corrections. Both our ARCL and the NRC calculations are based on human intrusion radiation exposure scenario/pathway analyses. The results of the 
TABLE 6.3.1 Comparison of Unrestricted Use Allowable Residual

Contamination Level Values with Existing Guidance

\begin{tabular}{|c|c|c|c|c|c|}
\hline \multirow[b]{2}{*}{ Radionuclide } & \multicolumn{2}{|c|}{$\begin{array}{c}\text { Removable } \\
\text { Surface Contamination } \\
\left(\mathrm{dpm} / 100 \mathrm{~cm}^{2}\right) \\
\end{array}$} & \multicolumn{3}{|c|}{$\begin{array}{l}\text { Soil Contamination at Depths } \\
\text { Between } 1 \text { and } 4 \mathrm{~m}(\mathrm{pC} / \mathrm{g})\end{array}$} \\
\hline & $\begin{array}{c}\text { Reg. Guide } \\
1.86 \\
\end{array}$ & $\mathrm{ARCL}$ & 10 CFR $61(a)$ & $\begin{array}{l}\text { Reported } \\
\text { ARCL (b) }\end{array}$ & $\begin{array}{l}\text { Modified } \\
\text { ARCL }(c)\end{array}$ \\
\hline${ }^{14} \mathrm{C}$ & 5,000 & 180,000 & $5.0 E+6^{(d)}$ & $1.0 \mathrm{E}+5$ & $5.0 \mathrm{E}+6$ \\
\hline${ }^{60} \mathrm{Co}$ & 1,000 & 400 & $4.0 E+8$ & $3.0 \mathrm{E}+6$ & $2.0 E+8$ \\
\hline${ }^{63} \mathrm{Ni}$ & 5,000 & 800 & $2.0 E+6$ & 200 & $6.0 E+5$ \\
\hline${ }^{9} 0 \mathrm{Sr+D}(e)$ & 200 & 200 & $2.0 E+4$ & 6 & 1. .OE+4 \\
\hline $137 C s+D$ & 1,000 & 5,000 & $6.0 E+6$ & $2.0 E+4$ & $1.0 E+6$ \\
\hline $238 U+D$ & 1,000 & 4 & $3.0 E+4$ & 110 & $6.0 \mathrm{E}+4$ \\
\hline $239 p u$ & 20 & 3 & $1.0 E+4$ & 600 & $3.0 E+4$ \\
\hline
\end{tabular}

(a) Based on $500 \mathrm{mrem} / \mathrm{yr}$ to total body through intrusion scenarios for Class $\mathrm{A}$ waste, converted from $\mathrm{Ci} / \mathrm{cm}^{3}$ using an assumed soil density of $1.6 \mathrm{~g} / \mathrm{cm}^{3}$.

(b) Based on $10 \mathrm{mrem} / \mathrm{yr}$ to the 1 imiting organ through intrusion scenarios at $T=100$ years and corrected to ARCL at $T=0$.

(c) Based on $500 \mathrm{mrem} / \mathrm{yr}$ to total body through intrusion scenarios at $T=100$ years and corrected to modified ARCL at $T=0$ years.

(d) Where $5.0 E+6=5.0 \times 106$.

(e) $+D$ means plus short-lived daughters.

comparison are shown in Table 6.3.1. It is not surprising that the values reported directly for the two methods bear little resemblance. However, with modification, the results can be shown to compare reasonably closely. First, the ARCL values can be increased by a factor of 50 so that the analyses have the same annual dose basis. After doing this, the ARCL values for ${ }^{14} \mathrm{C},{ }^{60} \mathrm{CO}$, and $137 \mathrm{CS}+\mathrm{D}$ are of the same order of magnitude as the NRC values. Next, the NRC developed disposal concentration 1 imits based on total-body dose, and our ARCL values are based on the limiting organ dose. In addition, the values reported in 10 CFR Part 61 reflect 100 years of radioactive decay to the time of loss of institutional controls. If these 
corrections are made, the results generally compare wi thin a factor of 3 . For ${ }^{14} \mathrm{C}$, we looked at root uptake of elemental carbon from graphite with a small concentration ratio (CR) value, while the NRC models are based on an assumed equilibrium relationship with $\mathrm{CO}_{2}$ gas. We felt that the root uptake factor approach more accurately modeled the behavior of ${ }^{14} \mathrm{C}$ in a subsoil graphite matrix; however, our modified ARCL result is the same as the value reported by the NRC.

\subsection{CONCLUSIONS}

A major consideration in developing decommissioning plans for the Hanford production reactors is the amount (or level) of radioactive contamination that can be allowed to remain at the site. This report contains a description of the methods for determining Allowable Residual Contamination Levels ( $A R C L$ ) for the radionuclides remaining at five generic categories of facilities in the 100 Areas at the Hanford Site. ARCL values are reported for a representative mixture of radionuclides and are based on a scenario/exposure pathway analysis and compliance with an annual dose limit. These ARCL values show good agreement with the removable contamination levels reported by the NRC in Regulatory Guide 1.86 (U.S. AEC 1974) and with 1 and disposal limits (U.S. NRC 1982) if modification factors are applied. The data presented in this report can be modified by the reader to consider different mixtures of radionuclides or annual dose 1 imits (using the worksheet procedures developed in Appendix B), while maintaining site-specific exposure conditions. This method give the required flexibility that will permit an engineering consideration of al ternatives to unrestricted use (i.e., restricted or controlled use). The ARCL levels calculated in this report (or as modified by additional site-specific data) can be translated into instrument responses (using the worksheet discussed in Appendix B) and included as part of the overall Health Physics program for certifying release of the 100 Area facilities after decommissioning. 


\subsection{REFERENCES}

Anspaugh, L. R., J. H. Shinn, P. L. Phelps and N. C. Kennedy. 1975. "Resuspension and Redistribution of Plutonium in Soils." Health Phys. $29: 571-582$.

Code of Federal Regulations. Title 10, Part 20, "Standards for Protection Against Radiation."

Code of Federal Regulations. Title 40, Part 190, "Environmental Protection Standards for Nuclear Power Operations."

Code of Federal Regulations. Title 40, 192, "Environmental Protection Standards for Uranium Mi11 Tailings."

Dorian, J. J., and V. R. Richards. 1978. Radiological Characterization of the Retired 100 Areas. UNI-946. Prepared for the U.S. Department of Energy by United Nuclear Industries, Inc. (UNI). Richland, Washington.

Dunster, H. J. 1962. Maximum Permissible Levels of Skin Contamination. AHSB (RP)R28, United Kingdom Atomic Energy Authority, Authority Health and Safety Branch Report, Harwe11, Didcot, Berkshire.

Eckerman, K. F. and M. W. Young. 1980. A Methodology for Calculating Residual Radioactivity Levels Following Decommissioning. NUREG-0707, U.S. Nuclear Regulatory Commission, Washington, D.C.

Engel, R. L., J. Greenborg, and M. M. Hendrickson. 1966. ISOSHLD - A Computer Code for General Purpose Isotope Shielding Analysis. BNWL-236, Pacific Northwest Laboratory, Richland, Washington.

Federal Register, Vol. 46, No. 27. 11666-68(February 10, 1981). "Nuclear Regulatory Commission, 10CFR Parts 30, 40, 50, 70 and 72, Decommissioning Criteria for Nuclear Facilities; Notice of Availability of Draft Environmental Impact Statement."

Federal Register, Vol. 48, No. 3. 590-606(January 5, 1983). "Environmental Protection Agency, 40 CFR Part 192, Standards for Remedial Actions at Inactive Uranium Proecssing Sites - Final Rule."

General Electric Co. 1963. Hazardous Summary Report, Vo1. 3, Description of the 100-R, 100-C, 100-D, 100-DR, 100-F, and 100-H Production Reactor Plants. HW-74094, Richland, Washington. 
Gibson, J. A. B., and A. D. Wrixon. 1979. "Methods for the Calculation of Derived Working Limits for Surface Contamination by Low-Toxicity Radionuc lides." Health Physics 36(3):311-321.

Harmon, K. M., and J. C. King. 1975. Resource Book - Decommissioning of Contaminated Facilities at Hanford. PNL-MA-588, Pacific Northwest Laboratory, Richland, Washington.

Healy, J. W. 1971. Surface Contamination: Decision Levels. LA-4558-MS, Los Alamos Scientific Laboratory, Los Alamos, New Mexico.

Healy, J. W. 1974. A Proposed Interim Standard for Plutonium in Soils. LA-5483-MS, Los Alamos Scientific Laboratory, Los Alamos, New Mexico.

Healy, J.W., J. C. Rodgers and C. L. Wienke. 1979. Interim Soil Limits for D\&D Projects. LA-UR-79-1865-Rev., LOS Alamos Scientific Laboratory, Los Alamos, New Mexico.

Houston, J. R., D. L. Strenge, and E. C. Watson. 1976. DACRIN - A Computer Program for Calculating Organ Doses from Acute or Chronic Radionuclide Inhalation. BNWL-B-389, Pacific Northwest Laboratory, Richland, Washington.

International Commission on Radiological Protection (ICRP). 1966. "Deposition and Retention Models for Internal Dosimetry of the Human Respiratory Tract." Health Phys. 12:173-207.

Kennedy, W. E., Jr., E. C. Watson, G. R. Hoenes, and B. A. Napier. 1979. "A Method for Determining Acceptable Residual Radioactive Contamination Levels." Paper presented at the 24th Annual Meeting of the Health Physics Society, July 8-13, 1979, Philadelphia, Pennsylvania.

Kennedy, W. E., Jr., E. C. Watson, D. W. Murphy, B. J. Harrer, R. Harty and J. M. Aldrich. 1981. A Review of Removable Surface Contamination on Radioactive Materials Transportation Containers. NUREG/CR-1858 (PNL-3666), Richland, Washington.

Kennedy, W. E., Jr., R. L. Aaberg, B. A. Napier, and J. K. Soldat. 1982. Transuranic Advanced Disposal Systems: Preliminary Pu Waste Disposal Criteria for Hanford. PNL-4254, Pacific Northwest Laboratory, Richland, Washington.

Kennedy, W. E., Jr. and B. A. Napier. 1983. Allowable Residual Contamination Levels for Decommissioning the 115-F and 117-F Facilities at the Hanford Site. PNL-4704, Pacific Northwest Laboratory, Richland, Washington. 
Konzek, G. J., J. D. Ludwick, W. E. Kennedy, Jr., and R. I. Smith. 1981. Technology, Safety and Costs of Decommissioning Reference Nuclear Research and Test Reactors. NUREG/CR-1756, prepared for the U.S. Nuclear Regulatory Commission by Pacific Northwest Laboratory, Richland, Washington.

Mueller, M. A., W. E. Kennedy, Jr., and J. K. Soldat. 1981. Review of Soil Contamination Guidance. PNL-3866, Pacific Northwest Laboratory, Richland, Washington.

Murphy, E. S., and G. M. Holter. 1980. Technology, Safety and Costs of Decommissioning a Reference Low-Level Waste Burial Ground. NUREG/CR-0570, Vols. 1 and 2, report prepared for the Nuclear Regulatory Commission by Pacific Northwest Laboratory, Richland, Washington.

Napier, B. A., G. R. Hoenes, W. E. Kennedy, Jr., and E. C. Watson. 1979. "The Maximum Annual Dose Resulting from Residual Radioactive Contamination." Paper presented at the 24th Annual Meeting of the Health Physics Society, July 8-13, 1979, Philadelphia, Pennsylvania. Pacific Northwest Laboratory, Richland, Washington.

Napier, B. A., R. L. Roswe11, W. E. Kennedy, Jr., and D. L. Strenge. 1980. ARRRG and FOOD - Computer Programs for Calculating Radiation Dose to Man from Radionuclides in the Environment. PNL-3180, Pacific Northwest Laboratory, Richland, Washington.

Napier, B. A. 1982. A Method for Determining "Allowable Residual Comtamination Levels" of Radionuclide Mixtures in Soi1. PNL-3852, Pacific Northwest Laboratory, Richland, Washington.

Oak, H. D., G. M. Holter, W. E. Kennedy, Jr., and G. J. Konzek. 1980. Technology, Safety and Costs of Decommissioning a Reference Boiling-Water Reactor Power Station. NUREG/CR-0672, V01. 1 and 2, prepared for the U.S. Nuclear Regulatory Commission by Pacific Northwest Laboratory, Richland, Washington.

O'Donnell, F. R., S. J. Cotter, D. C. Kocher, E. L. Etnier, and A. P. Watson. 1975. Potential Radiation Dose to Man From Recycle of Metals Reclaimed From a Decommissioned Nuclear Power Plant. NUREG/CR-0134, Prepared for the U.S. Nuclear Regulatory Commission by Oak Ridge National Laboratory, Oak Ridge, Tennessee.

Schneider, J. K. and C. E. Jenkins. Technology, Safety, and Costs of Decommissioning a Reference Nuclear Fuel Reprocesing Plant. NUREG-0278, prepared for the U.S. Nuclear Regulatory Commission by Pacific Northwest Laboratory, Richland, Wasington. 
Smith, R. I., G. J. Konzek and W. E. Kennedy, Jr. 1978. Technology, Safety, and Costs of Decommissioning a Reference Pressurized Water Reactor Power Station. NUREG/CR-0130, Vo1. 1 and 2, prepared for the U.S. Nuclear Regulatory Commission by Pacific Northwest Laboratory, Richl and, Washington.

Simmons, G. L. et al. 1967. ISOSHLD II Code Revision to Include Calculation of Dose Rates from Shielded Bremstrahlung Sources. BNWL-236, Supplement 1, Pacific Northwest Laboratory, Richland, Washington.

Sunset Editorial Staff. 1959. Sunset Western Garden Book. Lane Publishing Co., Menlo Park, California.

U.S. Atomic Enery Commission. 1974. Termination of Operating Licenses for Nuclear Reactors. Regulatory Guide 1.86, Directorate of Regulatory Standards, Washington, D.C.

U.S. Department of Agriculture. 1951. Soil Survey Manual, Handbook No. 18, Washington, D.C.

U.S. Department of Energy. 1980. Environmental Assessment, F Area Decommissioning Program, Hanford Site, Richland, Benton County, Washington. DOE/EA-0120. Prepared by UNC Nuclear Industries. Richland, Washington.

U.S. Nuclear Regulatory Commission. 1976. Guidelines for Decontamination of Facilities and Equipment Prior to Release for Unrestricted Use or Termination of Licenses for By-Product, Source, or Special Nuclear Material. Washington, D.C.

U.S. Nuclear Regulatory Commission. 1980. Draft Environmental Impact Statement Concerning Proposed Rulemaking Exemption from Licensing Requirements for Smelted Alloys Containing Residual Technetium-99 and Low-Enriched Uranium. NUREG-0512, Washington, D.C.

U.S. Nuclear Regulatory Commission. 1981. Draft Environmental Impact Statement on 10 CFR Part 61, "Licensing Requirements for Land Disposal of Radioactive Waste." NUREG-0782, Vols. 1-4, Washington, D.C.

U.S. Nuclear Regulatory Commission. 1982. Final Environmental Impact Statement on 10 CFR Part 61, "Licensing Requirements for Land Disposal of Radioactive Waste." NUREG-0945, Washington, D.C.

Washington State University. 1970. Alfalfa Irrigation, E.M 3468. Cooperative Extension Service, Pullman, Washington. 


\section{APPENDIX A}

SCENARIO-SPECIFIC DOSES AND ALLOWABLE RESIDUAL CONTAMINATION LEVEL VALUES FOR FACILITIES IN THE 100 AREAS OF THE HANFORD SITE 
This appendix contains data tables in support of the ARCL calculations discussed in Sections 5.0 and 6.0 of this report. Two types of tables are included. Tables A.1 through A.14 contain listings of scenario-specific doses for each radionuclide in the representative radionuclide inventories, for restricted, controlled, and unrestricted use, and for surface and soil contamination conditions. The representative radionuclide inventories for each of the five categories of facilities are discussed and listed in Section 3.0. Tables A.15 through A.22 contain ARCL values for unrestricted use conditions for decay periods of $T=100$ and $T=300$ years. The restricted use ARCL values for $T=0$ are reported in Section 5.0. 
TABLE A.1. Scenario-Specific Doses - Restricted Use(a)

\begin{tabular}{|c|c|c|c|}
\hline Radionuclide & $\begin{array}{c}\text { Retention Basin } \\
\text { System Inventory } \\
\text { (Table } 3.1 .1) \\
\text { (rem/yr) } \\
\end{array}$ & $\begin{array}{c}\text { Nuclear Reactor } \\
\text { Inventory } \\
\text { (Table } 3.4 .1) \\
\text { (rem/yr) } \\
\end{array}$ & $\begin{array}{c}\text { Fuel Storage } \\
\text { Basin Inventory } \\
\text { (Table } 3.5 .1) \\
\text { (rem/yr) } \\
\end{array}$ \\
\hline $\begin{array}{l}{ }_{14}^{3} \mathrm{H} \\
{ }^{60}{ }_{\mathrm{CO}}^{\mathrm{C}}\end{array}$ & $\begin{array}{l}6.2 E-5(b) \\
6.3 E-3 \\
3.6 E+2\end{array}$ & $\begin{array}{l}8 \cdot 4 E-2 \\
1.1 E+0 \\
1.5 E+1\end{array}$ & $\begin{array}{c}4.6 E-11 \\
-(c) \\
5.8 E+2\end{array}$ \\
\hline $\begin{array}{l}{ }^{63} \mathrm{Ni} \\
{ }^{90}{ }_{\mathrm{C}} \mathrm{Sr+D}(\mathrm{d}) \\
\mathrm{Cs}+\mathrm{D}\end{array}$ & $\begin{array}{l}2.3 E+1 \\
1.7 E+0 \\
1.2 E+0\end{array}$ & $\begin{array}{l}7.8 E-1 \\
1.8 E+2 \\
5.1 E-1\end{array}$ & $\begin{array}{l}1.9 E+1 \\
3.8 E+2 \\
2.2 E+1\end{array}$ \\
\hline $\begin{array}{l}{ }^{152} \mathrm{Eu} \\
154 \mathrm{Eu} \\
238 \mathrm{U+D}\end{array}$ & $\begin{array}{l}3.1 E+2 \\
2.4 E+2 \\
9.4 E-1\end{array}$ & $\begin{array}{l}4.6 E+0 \\
6.2 E+0 \\
2.9 E-3\end{array}$ & $\begin{array}{l}1.0 E+2 \\
1.4 E+2 \\
1.1 E+1\end{array}$ \\
\hline $\begin{array}{l}238 \mathrm{Pu} \\
239 \mathrm{Pu} \\
241 \mathrm{Am} \\
\end{array}$ & $\begin{array}{c}1.1 E+1 \\
2.3 E+1 \\
- \\
\end{array}$ & $\begin{array}{l}8.6 \mathrm{E}+1 \\
5.2 \mathrm{E}+1 \\
1.0 \mathrm{E}+2 \\
\end{array}$ & $\begin{array}{c}6.2 E+1 \\
3.4 E+3 \\
- \\
\end{array}$ \\
\hline Total & $1.0 E+3$ & $4.5 E+2$ & $4.6 E+3$ \\
\hline
\end{tabular}

(a) Based on the intruder-explorer scenario (Section 4.0) and the facilityspecific radionuclide inventories (Section 3.0 ).

(b) Where $6.2 E-5=6.2 \times 10-5$

(c) A dash indicates that the radionuclide shown is not considered in the radionuclide inventory shown. 
TABLE A.2. Scenario-Specific Doses - Controlled Use(a)

\begin{tabular}{|c|c|c|c|}
\hline Radionuclide & $\begin{array}{l}\text { Retention Basin } \\
\text { System Inventory } \\
\text { (Table } 3.1 .1) \\
\text { (rem/yr) } \\
\end{array}$ & $\begin{array}{c}\text { Nuclear Reactor } \\
\text { Inventory } \\
\text { (Table } 3.4 .1) \\
\text { (rem/yr) } \\
\end{array}$ & $\begin{array}{c}\text { Fuel Storage } \\
\text { Basin Inventory } \\
\text { (Table } 3.5 .1) \\
\text { (rem/yr) } \\
\end{array}$ \\
\hline${ }^{3} \mathrm{H}$ & $1.5 \mathrm{E}-4(\mathrm{~b})$ & $2.1 \mathrm{E}-1$ & $1.1 \mathrm{E}-10$ \\
\hline $14 \mathrm{C}$ & $1.5 \mathrm{E}-2$ & $2.7 E+0$ & $-(c)$ \\
\hline${ }^{60} \mathrm{Co}$ & $9.0 E+2$ & $3.7 E+1$ & $1.4 E+3$ \\
\hline${ }_{0}^{63} \mathrm{Ni}$ & $5.8 \mathrm{E}+1$ & $1.9 E+0$ & $4.8 E+1$ \\
\hline${ }^{90} S r+D(d)$ & $4.2 E+0$ & $4.4 E+2$ & $9.6 \mathrm{E}+2$ \\
\hline${ }^{137} \mathrm{Cs}+\mathrm{D}$ & $2.9 E+0$ & $1.3 E+0$ & $5.5 E+1$ \\
\hline $152 \mathrm{Eu}$ & $7.9 \mathrm{E}+2$ & $1.2 E+1$ & $2.6 \mathrm{E}+2$ \\
\hline $\begin{array}{l}154 \\
238 \mathrm{Eu}\end{array}$ & $6.1 \mathrm{E}+2$ & $1.6 \mathrm{E}+1$ & $3.5 E+2$ \\
\hline$U+D$ & $2.3 E+0$ & $7.0 \mathrm{E}-3$ & $2.6 \mathrm{E}+1$ \\
\hline${ }^{238} \mathrm{Pu}$ & $2.7 E+1$ & $2.2 E+2$ & $1.6 \mathrm{E}+2$ \\
\hline${ }_{241}^{239} \mathrm{Pu}$ & $5.7 E+1$ & $1.3 E+2$ & $8.3 E+3$ \\
\hline $\mathrm{Am}$ & $=$ & $2.6 \mathrm{E}+2$ & - \\
\hline Totals & $2.4 E+3$ & $1.1 E+3$ & $1.2 E+4$ \\
\hline
\end{tabular}

(a) Based on the intruder-discovery scenario (Section 4.0) and the facilityspecific radionuclide inventories (Section 3.0).

(b) Where $1.5 \mathrm{E}-4=1.5 \times 10^{-4}$.

(c) $+D$ means plus short-lived daughters. 
TABLE A.3. Scenario-Specific Doses - Unrestricted Use Surface Contamination at $T=0$ Years $(a)$

\begin{tabular}{|c|c|c|c|}
\hline Radionuclide & $\begin{array}{c}\text { Retention Basin } \\
\text { System Inventory } \\
\text { (Table } 3.1 .1) \\
\text { (rem/yr) } \\
\end{array}$ & $\begin{array}{c}\text { Nuclear Reactor } \\
\text { Inventory } \\
\text { (Table } 3.4 .1) \\
\text { (rem/yr) } \\
\end{array}$ & $\begin{array}{c}\text { Fuel Storage } \\
\text { Basin Inventory } \\
\text { (Table } 3.5 .1) \\
\text { (rem/yr) } \\
\end{array}$ \\
\hline $\begin{array}{l}{ }_{6}^{3}{ }_{\mathrm{CO}}^{3} \mathrm{H} \\
\mathrm{CO}\end{array}$ & $\begin{array}{l}1.8 E-2(b) \\
1.8 E+0 \\
1.1 E+5\end{array}$ & $\begin{array}{l}2.4 E+1 \\
3.2 E+2 \\
4.6 E+3\end{array}$ & $\begin{array}{r}1.3 E-8 \\
-(c) \\
1.1 E+5\end{array}$ \\
\hline $\begin{array}{l}{ }_{90}^{63} \mathrm{Ni} \\
{ }_{137+D} \mathrm{Sr}(\mathrm{d})\end{array}$ & $\begin{array}{l}6.7 E+3 \\
5.1 E+2 \\
3.0 E+2\end{array}$ & $\begin{array}{l}2.2 E+2 \\
5.4 E+4 \\
1.3 E+2\end{array}$ & $\begin{array}{l}5.6 E+3 \\
1.2 E+5 \\
5.7 E+3\end{array}$ \\
\hline $\begin{array}{l}152 \mathrm{Eu} \\
154 \mathrm{Eu} \\
238_{U+D}\end{array}$ & $\begin{array}{l}9.4 E+4 \\
7.0 E+4 \\
2.8 E+2\end{array}$ & $\begin{array}{l}1.4 E+3 \\
1.8 E+3 \\
8.6 E-1\end{array}$ & $\begin{array}{l}3.1 E+4 \\
4.2 E+4 \\
3.2 E+3\end{array}$ \\
\hline $\begin{array}{l}238 \mathrm{Pu} \\
239 \mathrm{Pu} \\
241 \mathrm{Pu} \\
\quad \mathrm{Am} \\
\end{array}$ & $\begin{array}{c}3.4 E+3 \\
7.2 E+3 \\
- \\
\end{array}$ & $\begin{array}{l}2.7 E+4 \\
1.6 E+4 \\
3.1 E+4 \\
\end{array}$ & $\begin{array}{c}2.0 \mathrm{E}+4 \\
1.0 \mathrm{E}+6 \\
- \\
\end{array}$ \\
\hline Totals & $2.9 E+5$ & $1.4 E+5$ & $1.4 E+6$ \\
\hline
\end{tabular}

(a) Based on the resource salvage and resource recycle scenarios (Section 4.0) and the facility-specific radionuclide inventories (Section 3.0). (b) Where $1.8 \mathrm{E}-2=1.8 \times 10^{-2}$.

(c) A dash indicates that the radionuclide shown is not considered in the radionuclide inventory shown.

(d) $+D$ means plus short-lived daughters.

A. 4 
TABLE A.4. Scenario-Specific Doses - Unrestricted Use Surface Contamination at $T=100$ Years $(a)$

\begin{tabular}{|c|c|c|c|}
\hline Radionuclide & $\begin{array}{l}\text { Retention Basin } \\
\text { System Inventory } \\
\text { (Table } 3.1 .1) \\
\text { (rem/yr) }\end{array}$ & $\begin{array}{c}\text { Nuclear Reactor } \\
\text { Inventory } \\
\text { (Table } 3.4 .1) \\
\text { (rem/yr) } \\
\end{array}$ & $\begin{array}{c}\text { Fuel Storage } \\
\text { Basin Inventory } \\
\text { (Table } 3.5 .1) \\
\text { (rem/yr) } \\
\end{array}$ \\
\hline $\begin{array}{l}3 \mathrm{H} \\
{ }^{14} \mathrm{C} \\
{ }^{60} \mathrm{Co}\end{array}$ & $\begin{array}{l}7.4 E-5(b) \\
1.8 E+0 \\
2.2 E-1\end{array}$ & $\begin{array}{l}1.0 E-1 \\
3.2 E+2 \\
9.0 E-3\end{array}$ & $\begin{array}{c}5.6 E-11 \\
-(c) \\
3.5 E-1\end{array}$ \\
\hline $\begin{array}{l}{ }^{63} \mathrm{Ni} \\
{ }^{90} \mathrm{Sr}+\mathrm{D}(\mathrm{d}) \\
{ }^{3}{ }^{7} \mathrm{Cs}+\mathrm{D}\end{array}$ & $\begin{array}{l}3.4 E+3 \\
4.1 E+1 \\
3.0 E+1\end{array}$ & $\begin{array}{l}1.1 E+2 \\
4.4 E+3 \\
1.3 E+1\end{array}$ & $\begin{array}{l}2.8 E+3 \\
9.4 E+3 \\
5.7 E+2\end{array}$ \\
\hline $\begin{array}{l}{ }^{152} \mathrm{Eu} \\
154 \mathrm{Eu} \\
238 \mathrm{U}+\mathrm{D}\end{array}$ & $\begin{array}{l}5.7 E+2 \\
2.3 E+1 \\
2.8 E+2\end{array}$ & $\begin{array}{l}1.1 E+2 \\
1.1 E+1 \\
8.6 E-1\end{array}$ & $\begin{array}{l}1.9 E+2 \\
1.4 E+1 \\
3.2 E+3\end{array}$ \\
\hline $\begin{array}{l}238 \mathrm{Pu} \\
235 \mathrm{Pu} \\
2{ }^{241} \mathrm{Am}\end{array}$ & $\begin{array}{c}1.5 E+3 \\
7.2 E+3 \\
-\end{array}$ & $\begin{array}{l}2.2 E+4 \\
1.6 E+4 \\
2.7 E+4\end{array}$ & $\begin{array}{c}8.4 E+3 \\
1.0 E+6 \\
-\end{array}$ \\
\hline Totals & $1.3 \mathrm{E}+4$ & $7.0 \mathrm{E}+4$ & $1.0 \mathrm{E}+6$ \\
\hline
\end{tabular}

(a) Based on the resource salvage and resource recycle scenarios (Section 4.0) and the facility-specific radionuclide inventories (Section 3.0 ).

(b) Where $7.4 \mathrm{E}-5=7.4 \times 10^{-5}$.

(c) A dash indicates that the radionuclide shown is not considered in the radionuclide inventory shown.

(d) $+D$ means plus short-lived daughters. 
TABLE A.5. Scenario-Specific Doses - Unrestricted Use Surface Contamination at $\mathrm{T}=300$ Years

\begin{tabular}{|c|c|c|c|}
\hline Radionuclide & $\begin{array}{c}\text { Retention Basin } \\
\text { System Inventory } \\
\text { (Table } 3.1 .1 \text { ) } \\
\text { (rem/yr) } \\
\end{array}$ & $\begin{array}{c}\text { Nuclear Reactor } \\
\text { Inventory } \\
\text { (Table } 3.4 .1 \text { ) } \\
\text { (rem/yr) } \\
\end{array}$ & $\begin{array}{c}\text { Fuel Storage } \\
\text { Basin Inventory } \\
\text { (Table } 3.5 .1) \\
\text { (rem/yr) } \\
\end{array}$ \\
\hline $\begin{array}{l}{ }^{3} \mathrm{H} \\
{ }^{14} \mathrm{C} \\
{ }^{60} \mathrm{Co}\end{array}$ & $\begin{array}{l}1.3 E-9(b) \\
1.7 E+0 \\
8.4 E-13\end{array}$ & $\begin{array}{l}1.7 E-6 \\
3.1 E+2 \\
3.4 E-14\end{array}$ & $\begin{array}{r}9.6 \mathrm{E}-16 \\
-(\mathrm{c}) \\
1.3 \mathrm{E}-12\end{array}$ \\
\hline $\begin{array}{l}{ }^{63} \mathrm{Ni} \\
{ }^{90} \mathrm{Sr+D}(d) \\
137 \mathrm{Cs+D}\end{array}$ & $\begin{array}{l}8.4 \mathrm{E}+2 \\
2.6 \mathrm{E}-1 \\
3.0 \mathrm{E}-1\end{array}$ & $\begin{array}{l}2.8 E+1 \\
2.7 E+1 \\
1.3 E-1\end{array}$ & $\begin{array}{l}7.0 E+2 \\
6.1 E+1 \\
5.7 E+0\end{array}$ \\
\hline $\begin{array}{l}152 \mathrm{Eu} \\
15{ }^{15 \mathrm{Eu}} \\
238 \mathrm{U}+\mathrm{D}\end{array}$ & $\begin{array}{l}2.0 E-2 \\
2.4 E-6 \\
2.8 E+2\end{array}$ & $\begin{array}{l}7.3 \mathrm{E}-1 \\
3.9 \mathrm{E}-4 \\
8.6 \mathrm{E}-1\end{array}$ & $\begin{array}{l}6.8 E-3 \\
1.5 E-6 \\
3.2 E+3\end{array}$ \\
\hline $\begin{array}{l}238 \mathrm{Pu} \\
239 \mathrm{Pu} \\
241 \mathrm{Pm} \\
\end{array}$ & $\begin{array}{r}3.1 E+2 \\
7.2 E+3 \\
- \\
\end{array}$ & $\begin{array}{l}2.4 E+3 \\
1.6 E+4 \\
1.9 E+4 \\
\end{array}$ & $\begin{array}{r}1.8 \mathrm{E}+3 \\
1.0 \mathrm{E}+6 \\
- \\
\end{array}$ \\
\hline Totals & $8.3 E+3$ & $3.8 E+4$ & $1.0 E+6$ \\
\hline
\end{tabular}

(a) Based on the resource salvage and resource recycle scenarios (Section 4.0 ), the facility-specific radionuclide inventories (section 3.0 ) and an annual dose limit of $0.01 \mathrm{rem}$.

(b) Where $1.3 \mathrm{E}-9=1.3 \times 10^{-9}$.

(c) $+D$ means plus short-lived daughters. 

TABLE A.6. Scenario-Specific Doses - Unrestricted Use
Unconfined Soil at $T=0$ Years

\begin{tabular}{|c|c|c|c|c|c|}
\hline Radionuclide & $\begin{array}{c}\text { Retention Basin } \\
\text { System Inventory } \\
\text { (Table } 3.1 .1) \\
\text { (rem/yr) } \\
\end{array}$ & $\begin{array}{c}\text { Miscell laneous } \\
\text { Cribs and } \\
\text { (Table } 3.2 .2) \\
\text { (rem/yr) } \\
\end{array}$ & $\begin{array}{c}\text { Solid Waste } \\
\text { Burial Grounds } \\
\text { (Table 3.3.2) } \\
\text { (rem/yr) } \\
\end{array}$ & $\begin{array}{c}\text { Nuclear Reactor } \\
\text { Inventory } \\
\text { (Table } 3.4 .1 \text { ) } \\
\text { (rem/yr) } \\
\end{array}$ & $\begin{array}{c}\text { Fuel Storage } \\
\text { Basin Inventory } \\
\text { (Table 3.5.1) } \\
\text { (rem/yr) }\end{array}$ \\
\hline $\begin{array}{l}{ }^{3} \mathrm{H} \\
{ }^{14} \mathrm{C} \\
{ }^{60} \mathrm{Co}\end{array}$ & $\begin{array}{l}8.2 E-14(b) \\
1.2 E-10 \\
3.1 E-6\end{array}$ & $\begin{array}{l}2.0 \mathrm{E}-12 \\
1.8 \mathrm{E}-8 \\
2.4 \mathrm{E}-3\end{array}$ & $\begin{array}{c}-(c) \\
1.0 \mathrm{E}-2\end{array}$ & $\begin{array}{l}1.1 \mathrm{E}-10 \\
2.2 \mathrm{E}-8 \\
9.0 \mathrm{E}-5\end{array}$ & $\begin{array}{c}6.0 \mathrm{E}-20 \\
- \\
3.5 \mathrm{E}-3\end{array}$ \\
\hline $\begin{array}{l}{ }^{63} \mathrm{Ni} \\
{ }^{90} \mathrm{Sr+D}(\mathrm{d}) \\
{ }^{137} \mathrm{Cs}+\mathrm{D}\end{array}$ & $\begin{array}{l}1.2 \mathrm{E}-4 \\
5.7 \mathrm{E}-5 \\
1.8 \mathrm{E}-5\end{array}$ & $\begin{array}{c}- \\
9.4 \mathrm{E}-3 \\
8.6 \mathrm{E}-4\end{array}$ & $\begin{array}{l}4.5 E-6 \\
1.8 E-3 \\
3.4 E-5\end{array}$ & $\begin{array}{l}4.2 E-6 \\
6.0 E-3 \\
7.8 E-6\end{array}$ & $\begin{array}{l}1.0 \mathrm{E}-4 \\
1.3 \mathrm{E}-2 \\
3.2 \mathrm{E}-4\end{array}$ \\
\hline $\begin{array}{l}{ }^{152} \mathrm{Eu} \\
154 \mathrm{Eu} \\
238 \mathrm{U}+\mathrm{D}\end{array}$ & $\begin{array}{l}1.8 E-3 \\
8.6 E-4 \\
2.4 E-9\end{array}$ & $\begin{array}{l}6.0 E-4 \\
2.0 E-5 \\
3.5 E-8\end{array}$ & $\begin{array}{l}4.6 \mathrm{E}-4 \\
2.3 \mathrm{E}-4 \\
7.9 \mathrm{E}-9\end{array}$ & $\begin{array}{l}2.6 \mathrm{E}-5 \\
2.2 \mathrm{E}-5 \\
7.0 \mathrm{E}-12\end{array}$ & $\begin{array}{l}6.0 E-4 \\
5.2 E-4 \\
2.8 E-8\end{array}$ \\
\hline $\begin{array}{l}238 \mathrm{Pu} \\
239 \mathrm{Pu} \\
2{ }^{21} \mathrm{Am}\end{array}$ & $\begin{array}{c}3.0 E-9 \\
6.7 E-9 \\
-\end{array}$ & $\begin{array}{c}5.6 E-9 \\
5.9 E-7 \\
-\end{array}$ & $\begin{array}{c}- \\
9.7 \mathrm{E}-9 \\
-\end{array}$ & $\begin{array}{l}2.4 \mathrm{E}-8 \\
2.2 \mathrm{E}-8 \\
5.4 \mathrm{E}-8 \\
\end{array}$ & $\begin{array}{c}1.7 \mathrm{E}-8 \\
1.4 \mathrm{E}-6 \\
-\end{array}$ \\
\hline Total s & $2.9 E-3$ & $1.4 \mathrm{E}-2$ & $1.2 \mathrm{E}-2$ & $6.2 \mathrm{E}-3$ & $1.8 \mathrm{E}-2$ \\
\hline
\end{tabular}

(a) Based on the residential/home-garden scenario (Section 4.0) and the radionuclide inventories for each facility (Section 3.0).

(b) Where $8.2 \mathrm{E}-14=8.2 \times 10^{-14}$.

(c) A dash indicates that the radionuclide shown is not considered in the radionuclide inventory shown.

(d) $+D$ means plus short-lived daughters. 
TABLE A.7. Scenario-Specific Doses - Unrestricted Use Unconfined Soil at $T=100$ Years $(\mathrm{a})$

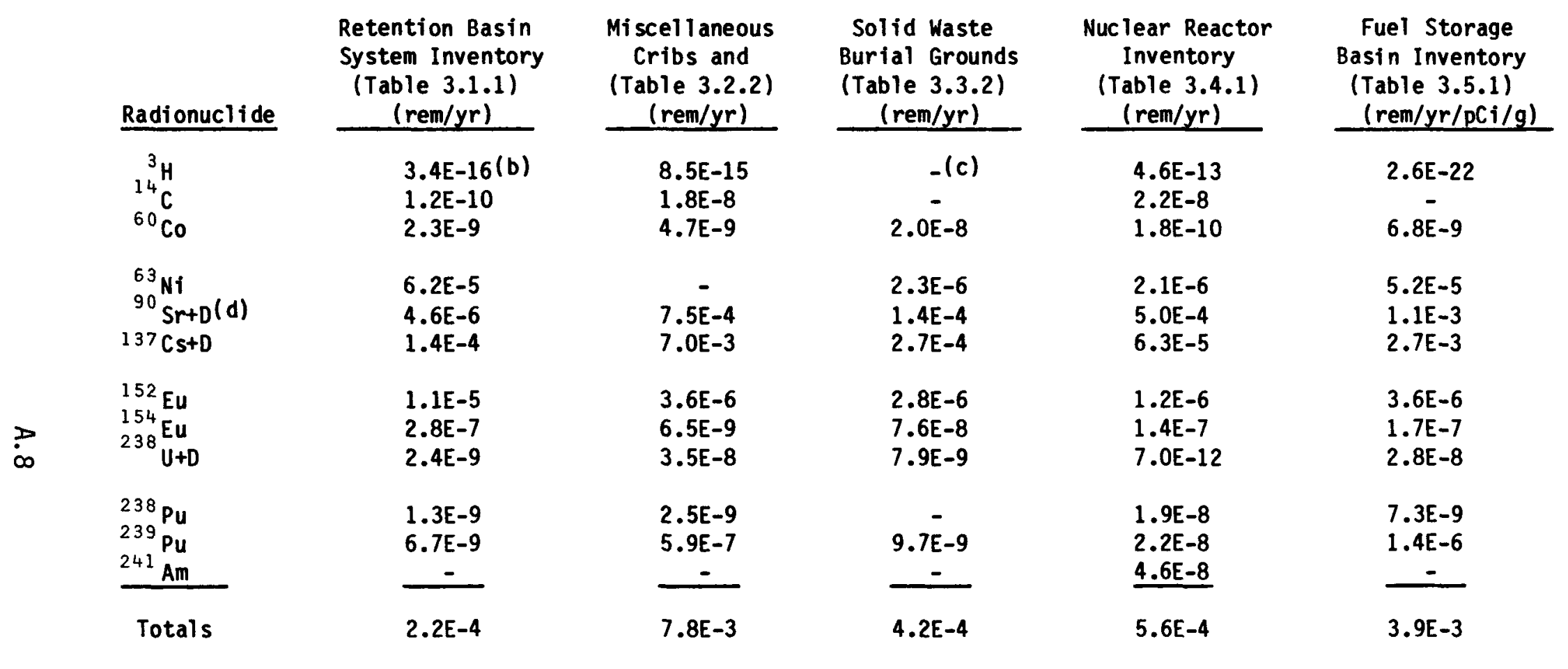

(a) Based on the residential/home-garden scenario (Section 4.0) and the radionuclide inventories of each facility (Section 3.0 ).

(b) Where $3.4 \mathrm{E}-16=3.4 \times 10^{-16}$.

(c) A dash indicates that the radionuclide shown is not considered in the radionuclide inventory shown.

(d) $+D$ means plus short-lived daughters. 
TABLE A.8. Scenario-Specific Dose - Unrestricted Use Unconfined Soil at $T=300$ Years $(a)$

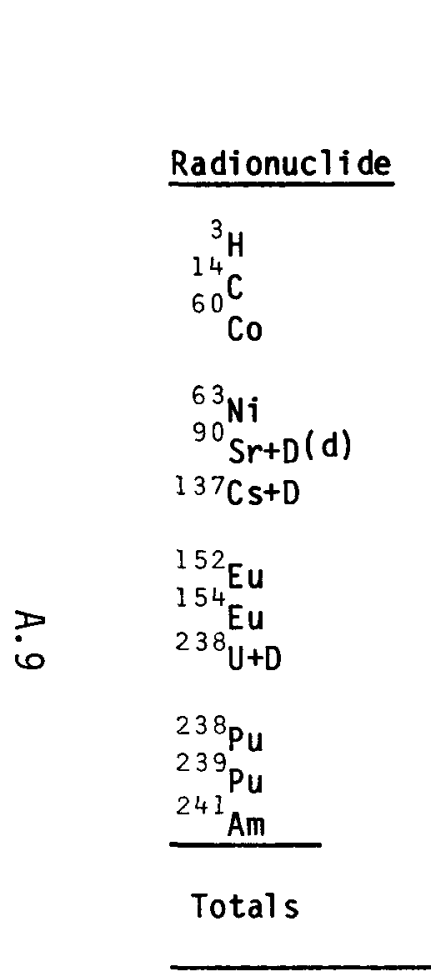

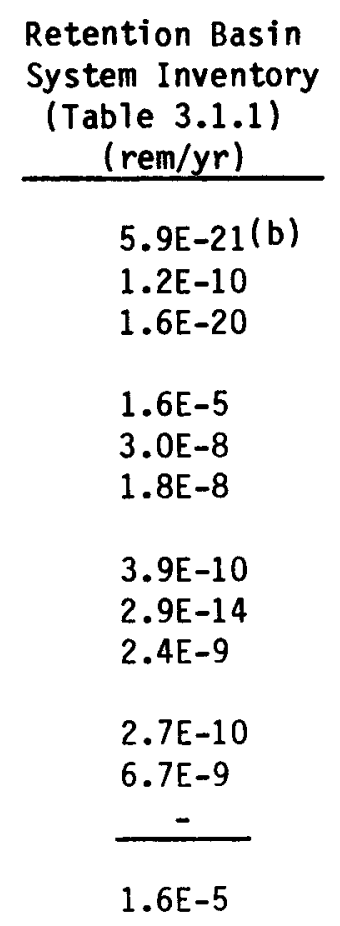

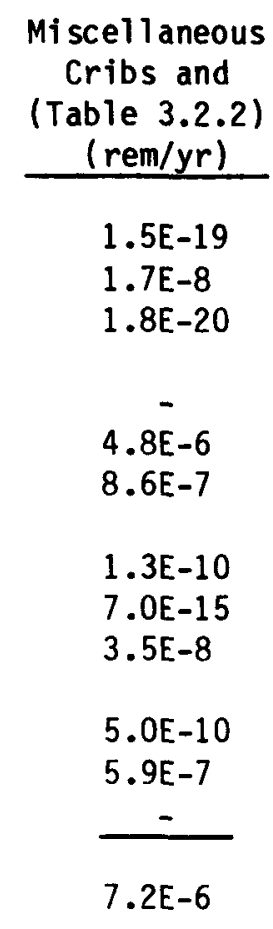

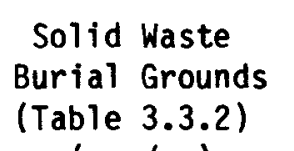

(Table 3.3.2)

(rem/yr)

$$
-(c)
$$$$
-
$$

$7.4 \mathrm{E}-20$

\subsection{E-7}

\section{$9.5 \mathrm{E}-7$}

3. $4 \mathrm{E}-8$

$$
\begin{aligned}
& 3.4 \mathrm{E}-11 \\
& 7.6 \mathrm{E}-15 \\
& 7.9 \mathrm{E}-9
\end{aligned}
$$

$\begin{array}{r}- \\ 9.7 \mathrm{E}-9 \\ - \\ \hline\end{array}$

$1.5 \mathrm{E}-6$
Nuclear Reactor Inventory
(Table 3.4.1)
(rem/yr)
8. $0 \mathrm{E}-18$
2.2E-8
$6.7 E-22$

5.2E-7

3.1E-6

7.8E-9

\subsection{E-9}

4. $8 \mathrm{E}-12$

7. $0 \mathrm{E}-12$

\subsection{E-9}

2. $2 \mathrm{E}-8$

3.3E-8

3.7E-6
Fuel Storage Basin Inventory (Table 3.5.1) (rem/yr)

4.4E-27 $-$

2. $6 \mathrm{E}-20$

1. $3 \mathrm{E}-5$

$6.8 \mathrm{E}-6$

$3.2 \mathrm{E}-7$

1.3E-10

1. $8 \mathrm{E}-14$

2. $8 \mathrm{E}-8$

$1.5 E-9$

1. $4 \mathrm{E}-6$

$-$

(a) Based on the residential/home-garden scenario (Section 4.0 ) and the radionuclide inventories for each facility (Section 3.0).

(b) Where $5.9 \mathrm{E}-21=5.9 \times 10^{-21}$.

(c) A dash indicates that the radionuclide shown is not considered in the radionuclide inventory shown.

(d) $+D$ means plus short-lived daughters. 
TABLE A.9. Scenario-Specific Doses - Unrestricted Use Confined

Soil at Depths Between 1 and $4 \mathrm{~m}$ at $T=0$ Years $(a)$

\begin{tabular}{|c|c|c|c|c|c|}
\hline Radionuclide & $\begin{array}{c}\text { Retention Basin } \\
\text { System Inventory } \\
\text { (Table } 3.1 .1) \\
\text { (rem/yr) } \\
\end{array}$ & $\begin{array}{c}\text { Miscell aneous } \\
\text { Cribs and } \\
\text { (Table 3.2.2) } \\
\text { (rem/yr) } \\
\end{array}$ & $\begin{array}{c}\text { Solid Waste } \\
\text { Burial Grounds } \\
\text { (Table } 3.3 .2) \\
\text { (rem/yr) } \\
\end{array}$ & $\begin{array}{c}\text { Nuclear Reactor } \\
\text { Inventory } \\
\text { (Table } 3.4 .1 \text { ) } \\
\text { (rem/yr) } \\
\end{array}$ & $\begin{array}{c}\text { Fuel Storage } \\
\text { Basin Inventory } \\
\text { (Table } 3.5 .1) \\
\text { (rem/yr) } \\
\end{array}$ \\
\hline $\begin{array}{l}{ }^{3} \mathrm{H} \\
{ }^{14} \mathrm{C} \\
{ }^{60} \mathrm{Co}\end{array}$ & $\begin{array}{l}1.6 E-14(b) \\
2.4 E-11 \\
6.2 E-7\end{array}$ & $\begin{array}{l}4.0 E-13 \\
3.6 E-9 \\
4.8 E-4\end{array}$ & $\begin{array}{c}-(c) \\
-\bar{E}-3\end{array}$ & $\begin{array}{l}2.2 E-11 \\
2.2 E-9 \\
1.8 E-5\end{array}$ & $\begin{array}{c}1.2 \mathrm{E}-20 \\
- \\
7.0 \mathrm{E}-4\end{array}$ \\
\hline $\begin{array}{l}{ }^{63} \mathrm{Ni} \\
90 \mathrm{Sr+D}(d) \\
{ }_{13} \mathrm{Css}_{\mathrm{C}+\mathrm{D}}\end{array}$ & $\begin{array}{l}2.4 \mathrm{E}-5 \\
1.1 \mathrm{E}-5 \\
3.6 \mathrm{E}-6\end{array}$ & $\begin{array}{l}-\overline{-}-3 \\
1.9 \mathrm{E}-3 \\
1.7 \mathrm{E}-4\end{array}$ & $\begin{array}{l}9.0 E-7 \\
3.6 E-4 \\
6.9 E-6\end{array}$ & $\begin{array}{l}8.4 E-7 \\
1.2 E-3 \\
1.6 E-6\end{array}$ & $\begin{array}{l}2.0 E-5 \\
2.6 E-3 \\
6.9 E-5\end{array}$ \\
\hline $\begin{array}{l}152 \mathrm{Eu} \\
15 \mathrm{E}^{\mathrm{E} u} \\
238_{\mathrm{U}+D}\end{array}$ & $\begin{array}{l}3.6 E-4 \\
1.7 E-4 \\
4.8 E-10\end{array}$ & $\begin{array}{l}1.2 E-4 \\
4.0 E-6 \\
7.0 E-9\end{array}$ & $\begin{array}{l}9.2 E-5 \\
4.6 E-5 \\
1.6 E-9\end{array}$ & $\begin{array}{l}5.2 E-6 \\
4.4 E-6 \\
1.4 E-12\end{array}$ & $\begin{array}{l}1.2 E-4 \\
1.0 E-4 \\
5.6 E-9\end{array}$ \\
\hline $\begin{array}{l}23 q_{u} \\
23 p_{u} \\
241 \\
\text { Am }\end{array}$ & $\begin{array}{c}6.0 \mathrm{E}-10 \\
1.3 \mathrm{E}-9 \\
-\end{array}$ & $\begin{array}{c}1.1 E-9 \\
1.2 E-7 \\
-\end{array}$ & $1.9 \bar{E}-9$ & $\begin{array}{l}4.8 E-9 \\
4.4 E-9 \\
1.1 E-8\end{array}$ & $\begin{array}{c}3.4 E-9 \\
2.8 E-7 \\
-\end{array}$ \\
\hline Totals & $5.8 \mathrm{E}-4$ & $2.8 E-3$ & $2.4 \mathrm{E}-3$ & $1.2 \mathrm{E}-3$ & $3.7 E-3$ \\
\hline
\end{tabular}

(a) Based on the residental/construction and residential/home-garden scenarios (Section 4.0 ) and the radionuclide inventories for each facility (Section 3.0).

(b) Where $1.6 \mathrm{E}-14=1.6 \times 10-14$.

(c) A dash indicates that the radionuclide shown is not considered in the radionuclide inventory shown.

(d) $+D$ means plus short-lived daughters. 
TABLE A.10. Scenario-Specific Doses - Unrestricted Use Confined
Soil at Depths Between 1 and $4 \mathrm{~m}$ at $\mathrm{T}=100$ Years $(\mathrm{a})$

\begin{tabular}{|c|c|c|c|c|c|}
\hline Radionuclide & $\begin{array}{l}\text { Retention Basin } \\
\text { System Inventory } \\
\text { (Table 3.1.1) } \\
\text { (rem/yr) } \\
\end{array}$ & $\begin{array}{c}\text { Miscell laneous } \\
\text { Cribs and } \\
\text { (Table } 3.2 .2 \text { ) } \\
\text { (rem/yr) } \\
\end{array}$ & $\begin{array}{l}\text { Solid Waste } \\
\text { Burial Grounds } \\
\text { (Table } 3.3 .2 \text { ) } \\
\text { (rem/yr) } \\
\end{array}$ & $\begin{array}{c}\text { Nuclear Reactor } \\
\text { Inventory } \\
\text { (Table 3.4.1) } \\
\text { (rem/yr) } \\
\end{array}$ & $\begin{array}{c}\text { Fuel Storage } \\
\text { Basin Inventory } \\
\text { (Table } 3.5 .1) \\
\text { (rem/yr) }\end{array}$ \\
\hline $\begin{array}{l}{ }^{3} \mathrm{H} \\
{ }^{14} \mathrm{C} \\
{ }^{60} \mathrm{Co}\end{array}$ & $\begin{array}{l}6.8 E-17(b) \\
2.4 E-11 \\
4.6 E-10\end{array}$ & $\begin{array}{l}1.7 \mathrm{E}-15 \\
3.6 \mathrm{E}-9 \\
9.4 \mathrm{E}-10\end{array}$ & $\begin{array}{c}-(c) \\
4.0 E-9\end{array}$ & $\begin{array}{l}9.2 \mathrm{E}-14 \\
4.4 \mathrm{E}-9 \\
3.6 \mathrm{E}-11\end{array}$ & $\begin{array}{c}5.1 \mathrm{E}-23 \\
- \\
1.4 \mathrm{E}-9\end{array}$ \\
\hline $\begin{array}{l}{ }^{63} \mathrm{Ni} \\
{ }^{90} \mathrm{Sr}+\mathrm{D}(\mathrm{d}) \\
1{ }^{3}{ }^{\mathrm{C}} \mathrm{Cs+D}\end{array}$ & $\begin{array}{l}1.2 E-5 \\
9.2 E-7 \\
3.6 E-7\end{array}$ & $\begin{array}{c}- \\
1.5 E-4 \\
1.7 E-5\end{array}$ & $\begin{array}{l}4.6 E-7 \\
2.8 E-5 \\
6.7 E-7\end{array}$ & $\begin{array}{l}4.2 E-7 \\
1.0 E-4 \\
2.4 E-7\end{array}$ & $\begin{array}{l}1.0 E-5 \\
2.2 E-4 \\
6.9 E-5\end{array}$ \\
\hline $\begin{array}{l}152 \mathrm{Eu} \\
15^{15} \mathrm{Eu} \\
238 \mathrm{U}+\mathrm{D}\end{array}$ & $\begin{array}{l}2.2 \mathrm{E}-6 \\
5.6 \mathrm{E}-8 \\
4.8 \mathrm{E}-10\end{array}$ & $\begin{array}{l}7.2 \mathrm{E}-7 \\
1.3 \mathrm{E}-9 \\
7.0 \mathrm{E}-9\end{array}$ & $\begin{array}{l}5.6 \mathrm{E}-7 \\
1.5 \mathrm{E}-8 \\
1.6 \mathrm{E}-9\end{array}$ & $\begin{array}{l}2.4 \mathrm{E}-7 \\
2.8 \mathrm{E}-8 \\
1.4 \mathrm{E}-12\end{array}$ & $\begin{array}{l}7.2 \mathrm{E}-7 \\
3.4 \mathrm{E}-8 \\
5.6 \mathrm{E}-9\end{array}$ \\
\hline $\begin{array}{l}238 \mathrm{Pu} \\
239 \mathrm{Pu} \\
2{ }^{4} \mathrm{I} \\
\mathrm{Am}\end{array}$ & $\begin{array}{l}2.6 E-10 \\
1.3 E-9 \\
-\end{array}$ & $\begin{array}{l}5.0 E-10 \\
1.2 E-7 \\
-\end{array}$ & $1.9 E-9$ & $\begin{array}{l}3.8 \mathrm{E}-9 \\
4.4 \mathrm{E}-9 \\
9.3 \mathrm{E}-9\end{array}$ & $\begin{array}{c}1.5 E-9 \\
2.8 E-7 \\
-\end{array}$ \\
\hline Total s & $1.6 \mathrm{E}-5$ & $1.9 E-4$ & $3.1 \mathrm{E}-5$ & $1.0 E-4$ & $3.1 E-4$ \\
\hline
\end{tabular}

(a) Based on the residential/construction and residential/home-garden scenarios (Section 4.0 ) and the radionuclide inventories for each facility (Section 3.0).

(b) Where $6.8 \mathrm{E}-17=6.8 \times 10^{-17}$.

(c) A dash indicates that the radionuclide shown is not considered in the radionuclide inventory shown.

(d) $+D$ means plus short-lived daughters. 
TABLE A.11. Scenario-Specific Doses - Unrestricted Use Confined Soil at Depths Between 1 and $4 \mathrm{~m}$ at $\mathrm{T}=300$ Years $(\mathrm{a})$

\begin{tabular}{|c|c|c|c|c|c|}
\hline Radionuclide & $\begin{array}{c}\text { Retention Basin } \\
\text { System Inventory } \\
\text { (Table } 3.1 .1) \\
\text { (rem/yr) } \\
\end{array}$ & $\begin{array}{c}\text { Miscell aneous } \\
\text { Cribs and } \\
\text { (Table } 3.2 .2) \\
\text { (rem/yr) } \\
\end{array}$ & $\begin{array}{l}\text { Solid Waste } \\
\text { Burial Grounds } \\
\text { (Table 3.3.2) } \\
\text { (rem/yr) } \\
\end{array}$ & $\begin{array}{c}\text { Nuclear Reactor } \\
\text { Inventory } \\
\text { (Table } 3.4 .1) \\
\text { (rem/yr) } \\
\end{array}$ & $\begin{array}{c}\text { Fuel Storage } \\
\text { Basin Inventory } \\
\text { (Table } 3.5 .1) \\
\text { (rem/yr) } \\
\end{array}$ \\
\hline $\begin{array}{l}{ }_{14}^{3} \mathrm{H} \\
{ }^{60} \mathrm{C} \\
\mathrm{CO}^{\circ}\end{array}$ & $\begin{array}{l}1.2 E-21(b) \\
2.4 E-11 \\
3.2 E-21\end{array}$ & $\begin{array}{l}3.0 E-20 \\
3.4 E-9 \\
3.6 E-21\end{array}$ & $\begin{array}{c}-(c) \\
-\overline{5 E}-20\end{array}$ & $\begin{array}{l}1.6 E-18 \\
4.4 E-9 \\
1.3 E-22\end{array}$ & $\begin{array}{c}8.8 E-28 \\
- \\
5.2 E-21\end{array}$ \\
\hline $\begin{array}{l}{ }^{63} \mathrm{Ni} \\
90_{\mathrm{Sr}}^{\mathrm{D}} \\
137 \mathrm{Cs+D}\end{array}$ & $\begin{array}{l}3.2 E-6 \\
6.0 E-9 \\
3.6 E-9\end{array}$ & $\begin{array}{c}- \\
9.6 E-7 \\
1.7 E-7\end{array}$ & $\begin{array}{l}1.0 \mathrm{E}-7 \\
1.9 \mathrm{E}-7 \\
6.9 \mathrm{E}-9\end{array}$ & $\begin{array}{l}1.0 \mathrm{E}-7 \\
6.2 \mathrm{E}-7 \\
1.6 \mathrm{E}-9\end{array}$ & $\begin{array}{l}2.6 \mathrm{E}-6 \\
1.4 \mathrm{E}-6 \\
6.9 \mathrm{E}-7\end{array}$ \\
\hline $\begin{array}{l}{ }^{152} E u \\
154{ }^{E u} \\
238 u \\
U+D\end{array}$ & $\begin{array}{l}7.8 E-11 \\
5.8 E-15 \\
4.8 E-10\end{array}$ & $\begin{array}{l}2.6 E-11 \\
1.4 E-15 \\
7.0 E-9\end{array}$ & $\begin{array}{l}6.8 E-12 \\
1.5 E-15 \\
1.6 E-9\end{array}$ & $\begin{array}{l}1.5 E-9 \\
9.6 E-13 \\
1.4 E-12\end{array}$ & $\begin{array}{l}2.6 \mathrm{E}-11 \\
3.6 \mathrm{E}-15 \\
5.6 \mathrm{E}-9\end{array}$ \\
\hline $\begin{array}{l}23 \mathrm{pu} \\
23 \mathrm{Pu} \\
24 \mathrm{Pu} \\
241_{\mathrm{Am}}\end{array}$ & $\begin{array}{c}5.4 \mathrm{E}-11 \\
1.3 \mathrm{E}-9 \\
-\end{array}$ & $\begin{array}{c}1.0 \mathrm{E}-10 \\
1.2 \mathrm{E}-7 \\
-\end{array}$ & $1.9 \mathrm{E}-9$ & $\begin{array}{l}4.2 E-10 \\
4.4 E-9 \\
6.6 E-9\end{array}$ & $\begin{array}{c}3.0 \mathrm{E}-10 \\
2.8 \mathrm{E}-7 \\
- \\
\end{array}$ \\
\hline Totals & $3.2 \mathrm{E}-6$ & $1.5 \mathrm{E}-6$ & $3.1 E-7$ & $7.4 \mathrm{E}-7$ & $5.1 E-6$ \\
\hline
\end{tabular}

(a) Based on the residential/construction and residential/home-garden scenarios (Section 4.0 ) and the radionuclide inventories for each facility (Section 3.0).

(b) Where $1.2 \mathrm{E}-21=1.2 \times 10^{-21}$.

(c) A dash indicates that the radionuclide shown is not considered in the radionuclide inventory shown.

(d) $+D$ means plus short-lived daughters. 
TABLE A.12. Scenario-Specific Doses - Unrestricted Use Confined Soil at Depths $>5 \mathrm{~m}$ at $\mathrm{T}=0$ Years $(\mathrm{a})$

\begin{tabular}{|c|c|c|c|c|c|}
\hline Radionuclide & $\begin{array}{c}\text { Retention Basin } \\
\text { System Inventory } \\
\text { (Table } 3.1 .1) \\
\text { (rem/yr) } \\
\end{array}$ & $\begin{array}{c}\text { Miscell aneous } \\
\text { Cribs and } \\
\text { (Table } 3.2 .2) \\
\text { (rem/yr) } \\
\end{array}$ & $\begin{array}{c}\text { Solid Waste } \\
\text { Burial Grounds } \\
\text { (Table 3.3.2) } \\
\text { (rem/yr) } \\
\end{array}$ & $\begin{array}{c}\text { Nuclear Reactor } \\
\text { Inventory } \\
\text { (Table } 3.4 .1 \text { ) } \\
\text { (rem/yr) }\end{array}$ & $\begin{array}{c}\text { Fuel Storage } \\
\text { Basin Inventory } \\
\text { (Table } 3.5 .1) \\
\text { (rem/yr) }\end{array}$ \\
\hline $\begin{array}{l}{ }^{3} \mathrm{H} \\
{ }^{14} \mathrm{C} \\
{ }^{60} \mathrm{Co}\end{array}$ & $\begin{array}{l}8.2 E-16(b) \\
1.2 E-12 \\
1.9 E-8\end{array}$ & $\begin{array}{l}2.0 E-14 \\
1.8 E-10 \\
2.0 E-8\end{array}$ & $\begin{array}{c}-(c) \\
- \\
8.1 E-8\end{array}$ & $\begin{array}{l}1.1 \mathrm{E}-12 \\
2.2 \mathrm{E}-10 \\
7.3 \mathrm{E}-10\end{array}$ & $\begin{array}{c}6.0 \mathrm{E}-22 \\
- \\
7.8 \mathrm{E}-8\end{array}$ \\
\hline $\begin{array}{l}{ }^{63} \mathrm{Ni} \\
{ }^{90} \mathrm{Sr+D}(d) \\
{ }^{137} \mathrm{Cs+D}\end{array}$ & $\begin{array}{l}1.2 \mathrm{E}-6 \\
5.7 \mathrm{E}-7 \\
2.2 \mathrm{E}-9\end{array}$ & $\begin{array}{c}- \\
9.4 \mathrm{E}-5 \\
1.1 \mathrm{E}-7\end{array}$ & $\begin{array}{l}4.5 \mathrm{E}-8 \\
1.8 \mathrm{E}-5 \\
4.3 \mathrm{E}-9\end{array}$ & $\begin{array}{l}4.2 \mathrm{E}-8 \\
6.0 \mathrm{E}-5 \\
9.9 \mathrm{E}-10\end{array}$ & $\begin{array}{l}1.0 \mathrm{E}-6 \\
1.3 \mathrm{E}-4 \\
4.3 \mathrm{E}-8\end{array}$ \\
\hline $\begin{array}{l}152 \mathrm{Eu} \\
154 \mathrm{Eu} \\
238 \mathrm{U}+\mathrm{D}\end{array}$ & $\begin{array}{l}1.1 E-10 \\
2.1 E-10 \\
2.4 E-11\end{array}$ & $\begin{array}{l}3.6 E-11 \\
4.8 E-12 \\
3.5 E-10\end{array}$ & $\begin{array}{l}2.8 \mathrm{E}-11 \\
5.5 \mathrm{E}-11 \\
7.9 \mathrm{E}-11\end{array}$ & $\begin{array}{l}1.6 \mathrm{E}-12 \\
5.3 \mathrm{E}-12 \\
7.0 \mathrm{E}-14\end{array}$ & $\begin{array}{l}3.6 \mathrm{E}-11 \\
1.2 \mathrm{E}-10 \\
2.6 \mathrm{E}-10\end{array}$ \\
\hline $\begin{array}{l}2{ }^{28} \mathrm{Pu} \\
239 \mathrm{Pu} \\
241 \mathrm{Am}\end{array}$ & $\begin{array}{c}7.8 \mathrm{E}-12 \\
2.6 \mathrm{E}-11 \\
-\end{array}$ & $\begin{array}{c}1.5 \mathrm{E}-11 \\
1.6 \mathrm{E}-9 \\
-\end{array}$ & $2.6 \mathrm{E}-1$ & $\begin{array}{l}6.2 \mathrm{E}-11 \\
6.0 \mathrm{E}-10 \\
2.8 \mathrm{E}-10\end{array}$ & $\begin{array}{c}4.5 \mathrm{E}-11 \\
3.8 \mathrm{E}-9 \\
-\end{array}$ \\
\hline Totals & $1.8 \mathrm{E}-6$ & $9.4 \mathrm{E}-5$ & $1.8 \mathrm{E}-5$ & $6.0 \mathrm{E}-5$ & $1.3 E-4$ \\
\hline
\end{tabular}

(a) Based on the residential/home-garden scenario with a root penetration factor of $1 \%$ (Section 4.0 ) and the radionuclide inventories for each facility (Section 3.0 ).

(b) Where $8.2 \mathrm{E}-16=8.6 \times 10^{-16}$.

(c) to means plus short-lived daughters. 
TABLE A.13. Scenario-Specific Doses - Unrestrjcted Use Confined Soit at Depths $\geq 5 \mathrm{~m}$ at $\mathrm{T}=100$ Years $(\mathrm{a})$

\begin{tabular}{|c|c|c|c|c|c|}
\hline Radionuclide & $\begin{array}{l}\text { Retention Basin } \\
\text { System Inventory } \\
\text { (Table 3.1.1) } \\
\text { (rem/yr) } \\
\end{array}$ & $\begin{array}{c}\text { Miscell aneous } \\
\text { Cribs and } \\
\text { (Table } 3.2 .2 \text { ) } \\
\text { (rem/yr) } \\
\end{array}$ & $\begin{array}{c}\text { Solid Waste } \\
\text { Burial Grounds } \\
\text { (Table 3.3.2) } \\
\text { (rem/yr) } \\
\end{array}$ & $\begin{array}{c}\text { Nuclear Reactor } \\
\text { Inventory } \\
\text { (Table 3.4.1) } \\
\text { (rem/yr) } \\
\end{array}$ & $\begin{array}{c}\text { Fuel Storage } \\
\text { Basin Inventory } \\
\text { (Table } 3.5 .1) \\
\text { (rem/yr) } \\
\end{array}$ \\
\hline $\begin{array}{l}{ }^{3} \mathrm{H} \\
1{ }^{4} \mathrm{C} \\
{ }^{60} \mathrm{CO}\end{array}$ & $\begin{array}{l}3.4 \mathrm{E}-18(\mathrm{~b}) \\
1.2 \mathrm{E}-12 \\
3.5 \mathrm{E}-14\end{array}$ & $\begin{array}{l}8.5 E-17 \\
1.8 E-10 \\
3.8 E-14\end{array}$ & $\begin{array}{c}-(c) \\
- \\
1.6 E-13\end{array}$ & $\begin{array}{l}4.6 E-15 \\
2.2 E-10 \\
1.4 E-15\end{array}$ & $\begin{array}{c}2.6 \mathrm{E}-24 \\
- \\
5.5 \mathrm{E}-14\end{array}$ \\
\hline $\begin{array}{l}{ }^{63} \mathrm{Ni} \\
{ }^{90} \mathrm{Ni} \\
137 \mathrm{Sr+D}(d) \\
\mathrm{Cs}+\mathrm{D}\end{array}$ & $\begin{array}{l}6.0 \mathrm{E}-7 \\
4.6 \mathrm{E}-8 \\
2.2 \mathrm{E}-10\end{array}$ & $\begin{array}{c}- \\
7.5 \mathrm{E}-6 \\
1.1 \mathrm{E}-8\end{array}$ & $\begin{array}{l}2.2 E-8 \\
1.4 E-6 \\
4.3 E-10\end{array}$ & $\begin{array}{l}2.1 E-8 \\
5.0 E-6 \\
9.9 E-11\end{array}$ & $\begin{array}{l}5.2 E-7 \\
1.1 E-5 \\
4.3 E-9\end{array}$ \\
\hline $\begin{array}{l}152 E u \\
154 E u \\
238 U+D\end{array}$ & $\begin{array}{l}6.6 E-13 \\
6.8 E-14 \\
2.4 E-11\end{array}$ & $\begin{array}{l}2.2 E-13 \\
1.6 E-15 \\
3.5 E-10\end{array}$ & $\begin{array}{l}1.7 E-13 \\
1.8 E-14 \\
7.9 E-11\end{array}$ & $\begin{array}{l}1.3 E-13 \\
3.2 E-14 \\
7.0 E-14\end{array}$ & $\begin{array}{l}2.2 E-13 \\
4.0 E-14 \\
2.6 E-10\end{array}$ \\
\hline $\begin{array}{l}238 \mathrm{Pu} \\
239 \mathrm{Pu} \\
241 \mathrm{Pu} \\
{ }^{4} \mathrm{Am}\end{array}$ & $\begin{array}{c}3.5 E-12 \\
2.6 E-11 \\
-\end{array}$ & $\begin{array}{c}6.6 \mathrm{E}-12 \\
1.6 \mathrm{E}-9 \\
-\end{array}$ & $2.6 \bar{E}-11$ & $\begin{array}{l}5.0 E-11 \\
6.0 E-10 \\
2.4 E-10\end{array}$ & $\begin{array}{c}1.9 E-11 \\
3.8 E-9 \\
-\end{array}$ \\
\hline Totals & $6.5 \mathrm{E}-7$ & $7.5 \mathrm{E}-6$ & $1.4 \mathrm{E}-6$ & $5.0 \mathrm{E}-6$ & $1.1 \mathrm{E}-5$ \\
\hline
\end{tabular}

(a) Based on the residential/home-garden scenario with a root penetration factor of $1 \%$ (Section 4.0 ) and the radionuclide inventories for each facility (Section 3.0 ).

(b) Where $3.4 \mathrm{E}-18=3.4 \times 10^{-18}$.

(c) A dash indicates that the radionuclide shown is not considered in the radionuclide inventory shown.

(d) +D means plus short-lived daughters. 
TABLE A.14. Scenario-Specific Doses - Unrestrjcted Use Confined Soi1 at Depths $\geq 5 \mathrm{~m}$ at $\mathrm{T}=300$ Years $(\mathrm{a})$

\begin{tabular}{|c|c|c|c|c|c|}
\hline Radionuclide & $\begin{array}{c}\text { Retention Basin } \\
\text { System Inventory } \\
\text { (Table } 3.1 .1) \\
\text { (rem/yr) } \\
\end{array}$ & $\begin{array}{c}\text { Miscel l aneous } \\
\text { Cribs and } \\
\text { (Table } 3.2 .2 \text { ) } \\
\text { (rem/yr) } \\
\end{array}$ & $\begin{array}{c}\text { Solid Waste } \\
\text { Burial Grounds } \\
\text { (Table } 3.3 .2 \text { ) } \\
\text { (rem/yr) } \\
\end{array}$ & $\begin{array}{c}\text { Nuclear Reactor } \\
\text { Inventory } \\
\text { (Table } 3.4 .1) \\
\text { (rem/yr) } \\
\end{array}$ & $\begin{array}{c}\text { Fuel Storage } \\
\text { Basin Inventory } \\
\text { (Table } 3.5 .1) \\
\text { (rem/yr) } \\
\end{array}$ \\
\hline $\begin{array}{l}{ }_{14}^{3} \mathrm{H} \\
6{ }_{0} \mathrm{C} \\
\mathrm{CO}\end{array}$ & $\begin{array}{l}6.0 \mathrm{E}-23(\mathrm{~b}) \\
1.1 \mathrm{E}-12 \\
1.3 \mathrm{E}-25\end{array}$ & $\begin{array}{l}1.5 \mathrm{E}-21 \\
1.7 \mathrm{E}-10 \\
1.4 \mathrm{E}-25\end{array}$ & $\begin{array}{c}-(c) \\
- \\
6.0 E-25\end{array}$ & $\begin{array}{l}8.0 \mathrm{E}-20 \\
2.1 \mathrm{E}-10 \\
5.4 \mathrm{E}-27\end{array}$ & $\begin{array}{c}4.4 \mathrm{E}-29 \\
- \\
2.1 \mathrm{E}-25\end{array}$ \\
\hline $\begin{array}{l}{ }^{63 N i} \\
90 \mathrm{Sr+D}(\mathrm{d}) \\
{ }^{137} \mathrm{Cs+D}\end{array}$ & $\begin{array}{l}1.5 \mathrm{E}-7 \\
3.0 \mathrm{E}-10 \\
2.2 \mathrm{E}-12\end{array}$ & $\begin{array}{c}- \\
4.8 E-8 \\
1.1 E-10\end{array}$ & $\begin{array}{l}5.6 \mathrm{E}-9 \\
9.1 \mathrm{E}-9 \\
4.3 \mathrm{E}-12\end{array}$ & $\begin{array}{l}5.2 E-9 \\
3.1 E-8 \\
9.9 E-13\end{array}$ & $\begin{array}{l}1.2 \mathrm{E}-7 \\
6.8 \mathrm{E}-8 \\
4.3 \mathrm{E}-11\end{array}$ \\
\hline $\begin{array}{l}152 \\
154 \mathrm{Eu} \\
238 \mathrm{Eu} \\
{ }_{U+D}\end{array}$ & $\begin{array}{l}2.3 \mathrm{E}-17 \\
7.0 \mathrm{E}-21 \\
2.4 \mathrm{E}-11\end{array}$ & $\begin{array}{l}7.8 \mathrm{E}-18 \\
1.7 \mathrm{E}-22 \\
3.5 \mathrm{E}-10\end{array}$ & $\begin{array}{l}2.0 \mathrm{E}-18 \\
1.8 \mathrm{E}-21 \\
7.9 \mathrm{E}-11\end{array}$ & $\begin{array}{l}\text { 8.4E-16 } \\
1.2 \mathrm{E}-18 \\
7.0 \mathrm{E}-14\end{array}$ & $\begin{array}{l}7.8 E-18 \\
4.3 E-21 \\
2.6 E-10\end{array}$ \\
\hline $\begin{array}{r}238 \\
239 \mathrm{Pu} \\
241 \mathrm{Pu} \\
\quad \mathrm{Am} \\
\end{array}$ & $\begin{array}{c}7.0 \mathrm{E}-13 \\
2.6 \mathrm{E}-11 \\
- \\
\end{array}$ & $\begin{array}{c}1.3 \mathrm{E}-12 \\
1.6 \mathrm{E}-9 \\
-\end{array}$ & $\begin{array}{c}- \\
- \\
-\end{array}$ & $\begin{array}{l}5.6 \mathrm{E}-12 \\
6.0 \mathrm{E}-10 \\
1.7 \mathrm{E}-10\end{array}$ & $\begin{array}{c}4.0 E-12 \\
3.8 E-9 \\
-\end{array}$ \\
\hline Totals & $1.5 \mathrm{E}-7$ & $4.8 \mathrm{E}-8$ & $1.5 \mathrm{E}-8$ & $3.7 \mathrm{E}-8$ & $1.9 E-7$ \\
\hline
\end{tabular}

(a) Based on the residential/home-garden scenario with a root penetration factor of $1 \%$ (Section 4.0 ) and the radionuclide inventories for each facility (Section 3.0 ).

(b) Where $6.0 \mathrm{E}-23=6.0 \times 10-23$

(c) A dash indicates that the radionuclide shown is not considered in the radionuclide inventory shown.

(d) $+D$ means plus short-lived daughters. 
TABLE A.15. Allowable Residual Contamination Level Values for Decommissioned Facilities in the 100 Areas of the Hanford Site - Unrestricted Use Surface Contamination at $T=100$ Years $(a)$

\begin{tabular}{|c|c|c|c|}
\hline Radionuclide & $\begin{array}{r}\text { Retention Basin } \\
\text { System Inventory } \\
\text { (Table } 3.1 .1) \\
\left(\mathrm{dpm} / 100 \mathrm{~cm}^{2}\right) \\
\end{array}$ & $\begin{array}{c}\text { Nuclear Reactor } \\
\text { Inventory } \\
(\text { Table } 3.4 .1) \\
\left(\mathrm{dpm} / 100 \mathrm{~cm}^{2}\right) \\
\end{array}$ & $\begin{array}{l}\text { Fuel Storage } \\
\text { Basin Inventory } \\
\text { (Table } 3.5 .1 \text { ) } \\
\text { (dpm/100 } \mathrm{cm}^{2} \text { ) } \\
\end{array}$ \\
\hline${ }^{3} \mathrm{H}$ & $2.8 \mathrm{E}-1(\mathrm{~b})$ & $2.9 E+1$ & $2.4 \mathrm{E}-9$ \\
\hline${ }^{14} \mathrm{C}$ & $2.1 E+2$ & $3.0 E+3$ & $-(c)$ \\
\hline${ }^{60} \mathrm{Co}$ & $5.5 \mathrm{E}-2$ & 1.7E-4 & $9.7 \mathrm{E}-4$ \\
\hline${ }^{63} \mathrm{Ni}$ & $1.7 E+4$ & $4.3 E+1$ & $1.6 \mathrm{E}+2$ \\
\hline $\begin{array}{r}90 \mathrm{Sr}+\mathrm{D} \\
1{ }^{37} \mathrm{Cs}+\mathrm{D}\end{array}$ & $\begin{array}{l}5.9 \mathrm{E}+0 \\
9.6 \mathrm{E}+1\end{array}$ & $\begin{array}{l}4.9 \mathrm{E}+1 \\
3.2 \mathrm{E}+0\end{array}$ & $\begin{array}{l}1.5 \mathrm{E}+1 \\
2.0 \mathrm{E}+1\end{array}$ \\
\hline 152Eu & $3.1 E+2$ & $4.6 \mathrm{E}+0$ & $1.1 \mathrm{E}+0$ \\
\hline${ }^{154} \mathrm{Eu}$ & $7.3 E+0$ & $2.7 \mathrm{E}-1$ & $4.9 E-2$ \\
\hline $238 U+D$ & 7.3E-1 & $1.7 \mathrm{E}-4$ & $9.4 \mathrm{E}-2$ \\
\hline${ }^{238} \mathrm{Pu}$ & $3.1 E+0$ & $3.4 E+0$ & $1.9 \mathrm{E}-1$ \\
\hline 239Pu & 1. $6 \mathrm{E}+1$ & $2.7 E+0$ & $2.5 E+1$ \\
\hline $241 \mathrm{Am}$ & - & $3.4 E+0$ & - \\
\hline Total & $1.7 E+4$ & $3.1 E+3$ & $2.2 E+2$ \\
\hline
\end{tabular}

(a) Based on the resource salvage and resource recycle scenario (Section 4), the radionuclide inventories for each facility (Section 3.0), and an annual dose limit of 0.01 rem.

(b) Where $2.8 \mathrm{E}-1=2.8 \times 10^{-1}$.

(c) A dash indicates that the radionuclide shown is not considered in the radionuclide inventory shown.

(d) $+D$ means plus short-lived daughters. 
TABLE A.16. Allowable Residual Contamination Level Values for Decommissioned Facilities in the 100 Areas of the Hanford Site - Unrestricted Use Surface Contamination at $T=300$ Years $(a)$

\begin{tabular}{|c|c|c|c|}
\hline Radionuclide & $\begin{array}{l}\text { Retention Basin } \\
\text { System Inventory } \\
\text { (Table } 3.1 .1) \\
(\mathrm{dpm} / 100 \mathrm{~cm} 2) \\
\end{array}$ & $\begin{array}{c}\text { Nuclear Reactor } \\
\text { Inventory } \\
\text { (Table } 3.4 .1) \\
\left(\mathrm{dpm} / 100 \mathrm{~cm}^{2}\right) \\
\end{array}$ & $\begin{array}{l}\text { Fuel Storage } \\
\text { Rasin Inventory } \\
(\text { Table } 3.5 .1) \\
\left(\mathrm{dpm} / 100 \mathrm{~cm}^{2}\right) \\
\end{array}$ \\
\hline $3 \mathrm{H}$ & $2.9 E-5(b)$ & 1. $\cap \mathrm{E}-3$ & $1.4 \mathrm{E}-13$ \\
\hline${ }^{14} \mathrm{C}$ & $1.2 E+3$ & $5.8 E+3$ & $-(c)$ \\
\hline${ }^{60} \mathrm{Co}$ & $1.2 \mathrm{E}-12$ & $1.4 F-15$ & $1.3 \mathrm{E}-4$ \\
\hline $63 \mathrm{Ni}$ & $2.5 E+4$ & 2.?F+1 & $1.3 E+2$ \\
\hline $90 S r+D(d)$ & $2.2 E-1$ & $6.2 E-1$ & $3.3 E-1$ \\
\hline $137 \mathrm{Cs}+\mathrm{D}$ & $5.6 \mathrm{E}+0$ & $6.7 E-2$ & 7. $0 \mathrm{E}-1$ \\
\hline $152 \mathrm{Eu}$ & $6.5 \mathrm{E}-2$ & $6.2 E-?$ & $1.4 E-4$ \\
\hline $154 \mathrm{Eu}$ & $4.5 E-6$ & $2.0 E-5$ & 1.8E-8 \\
\hline $238 U+0$ & $4.3 E+0$ & $3.4 E-4$ & $3.2 E-1$ \\
\hline $238 \mathrm{Pu}$ & $3.6 \mathrm{E}+0$ & $7.8 E-1$ & 1. $3 \mathrm{E}-1$ \\
\hline $239 \mathrm{pu}$ & $9.1 E+1$ & $5.6 \mathrm{E}+0$ & $8.6 E+1$ \\
\hline $241 \mathrm{Am}$ & - & $4.9 E+0$ & - \\
\hline Totals & $2.6 E+4$ & $5.8 E+3$ & $2.2 E+2$ \\
\hline
\end{tabular}

(a) Based on the resource salvage and resource recycle scenario (Section 4), the radionuclide inventories for each facility (Section 3.0), and an annual dose limit of 0.01 rem.

(b) Where $2.9 \mathrm{E}-5=2.9 \times 10^{-5}$.

(c) A dash indicates that the radionuclide shown is not considered in the radionuclide inventory shown.

(d) $+D$ means plus short-lived daughters. 
TABLE A.17. Al lowable Residual Contamination Level Values for Decommissioned Facilities in the 100 Area of the Hanford Site - Unconfined Surface Soil at $T=100$ Years $(\mathrm{a})$

\begin{tabular}{|c|c|c|c|c|c|}
\hline Radionuclide & $\begin{array}{l}\text { Retention Basin } \\
\text { System Inventory } \\
\text { (Table 3.1.1) } \\
(\mathrm{pC} i / \mathrm{g}) \\
\end{array}$ & $\begin{array}{c}\text { Miscell laneous } \\
\text { Cribs and } \\
\text { (Table 3.2.2) } \\
(\mathrm{pCi} / \mathrm{g}) \\
\end{array}$ & $\begin{array}{c}\text { Solid Waste } \\
\text { Burial Grounds } \\
\text { (Table } 3.3 .2) \\
\quad(\mathrm{pCi} / \mathrm{g}) \\
\end{array}$ & $\begin{array}{c}\text { Nuclear Reactor } \\
\text { Inventory } \\
\text { (Table } 3.4 .1) \\
(\mathrm{pCi} / \mathrm{g}) \\
\end{array}$ & $\begin{array}{c}\text { Fuel Storage } \\
\text { Basin Inventory } \\
\text { (Table } 3.5 .1) \\
(\mathrm{pC} i / \mathrm{g}) \\
\end{array}$ \\
\hline $\begin{array}{l}{ }^{3} \mathrm{H} \\
{ }^{14} \mathrm{C} \\
6{ }^{60} \mathrm{Co}\end{array}$ & $\begin{array}{l}7.6 E-4(b) \\
5.8 E-1 \\
1.5 E-4\end{array}$ & $\begin{array}{l}2.5 E-4 \\
1.1 E+0 \\
2.2 E-6\end{array}$ & $\begin{array}{c}-(c) \\
5.7 E-3 \\
-\end{array}$ & $\begin{array}{l}1.7 E-1 \\
1.7 E+1 \\
9.8 E-7\end{array}$ & $\begin{array}{c}2.7 E-11 \\
- \\
1.1 E-5\end{array}$ \\
\hline $\begin{array}{l}{ }^{63} \mathrm{Ni} \\
{ }^{90} \mathrm{Sr+D}(d) \\
{ }^{137} \mathrm{Cs+D}\end{array}$ & $\begin{array}{l}4.4 E+1 \\
1.6 E-2 \\
2.2 E-2\end{array}$ & $\begin{array}{l}-\overline{-} \\
3.3 \mathrm{E}-2 \\
1.6 \mathrm{E}-1\end{array}$ & $\begin{array}{l}1.4 E+1 \\
4.6 E+0 \\
3.9 E+0\end{array}$ & $\begin{array}{l}2.5 \mathrm{E}-1 \\
2.8 \mathrm{E}-1 \\
1.9 \mathrm{E}-2\end{array}$ & $\begin{array}{l}1.8 E+0 \\
1.8 E-1 \\
2.4 E-1\end{array}$ \\
\hline $\begin{array}{l}152 \mathrm{Eu} \\
154 \mathrm{Eu} \\
{ }^{238} \mathrm{U}+\mathrm{D}\end{array}$ & $\begin{array}{l}8.4 E-1 \\
2.0 E-2 \\
2.0 E-3\end{array}$ & $\begin{array}{l}3.6 \mathrm{E}-3 \\
5.9 \mathrm{E}-6 \\
3.9 \mathrm{E}-4\end{array}$ & $\begin{array}{l}1.7 E+0 \\
4.3 E-2 \\
5.7 E-2\end{array}$ & $\begin{array}{l}2.7 \mathrm{E}-2 \\
1.5 \mathrm{E}-3 \\
9.8 \mathrm{E}-7\end{array}$ & $\begin{array}{l}1.3 \mathrm{E}-2 \\
5.5 \mathrm{E}-4 \\
1.1 \mathrm{E}-3\end{array}$ \\
\hline $\begin{array}{l}238 \mathrm{Pu} \\
239 \mathrm{Pu} \\
241 \\
{ }^{4} \mathrm{Am} \\
\end{array}$ & $\begin{array}{r}8.4 E-3 \\
4.0 E-2 \\
- \\
\end{array}$ & $\begin{array}{r}1.3 \mathrm{E}-4 \\
3.3 \mathrm{E}-2 \\
- \\
\end{array}$ & $\begin{array}{r}- \\
3.4 \mathrm{E}-1 \\
- \\
\end{array}$ & $\begin{array}{l}1.9 \mathrm{E}-2 \\
1.5 \mathrm{E}-2 \\
1.9 \mathrm{E}-2 \\
\end{array}$ & $\begin{array}{r}2.2 \mathrm{E}-3 \\
2.9 \mathrm{E}-1 \\
- \\
\end{array}$ \\
\hline Totals & $4.4 E+1$ & $1.3 \mathrm{E}+0$ & $2.4 E+1$ & $1.8 \mathrm{E}+1$ & $2.6 \mathrm{E}+0$ \\
\hline
\end{tabular}

(a) Based on the residential/home-garden scenario (Section 4.0), the radionuclide inventories for each facility decayed 100 years and normalized to $1 \mathrm{pCi} / \mathrm{g}$ (Section 3.0), and an annual dose limit of $0.01 \mathrm{rem}$.

(b) Where $7.6 \mathrm{E}-4=7.6 \times 10^{-4}$.

(c) A dash indicates that the radionuclide shown is not considered in the radionuclide inventory shown.

(d) $+D$ means plus short-lived daughters. 
TABLE A.18. Allowable Residual Contamination Level Values for Decommissioned Facilities in the 100 Areas of the Hanford Site - Unconfined Surface Soil at $T=300$ Years $(a)$

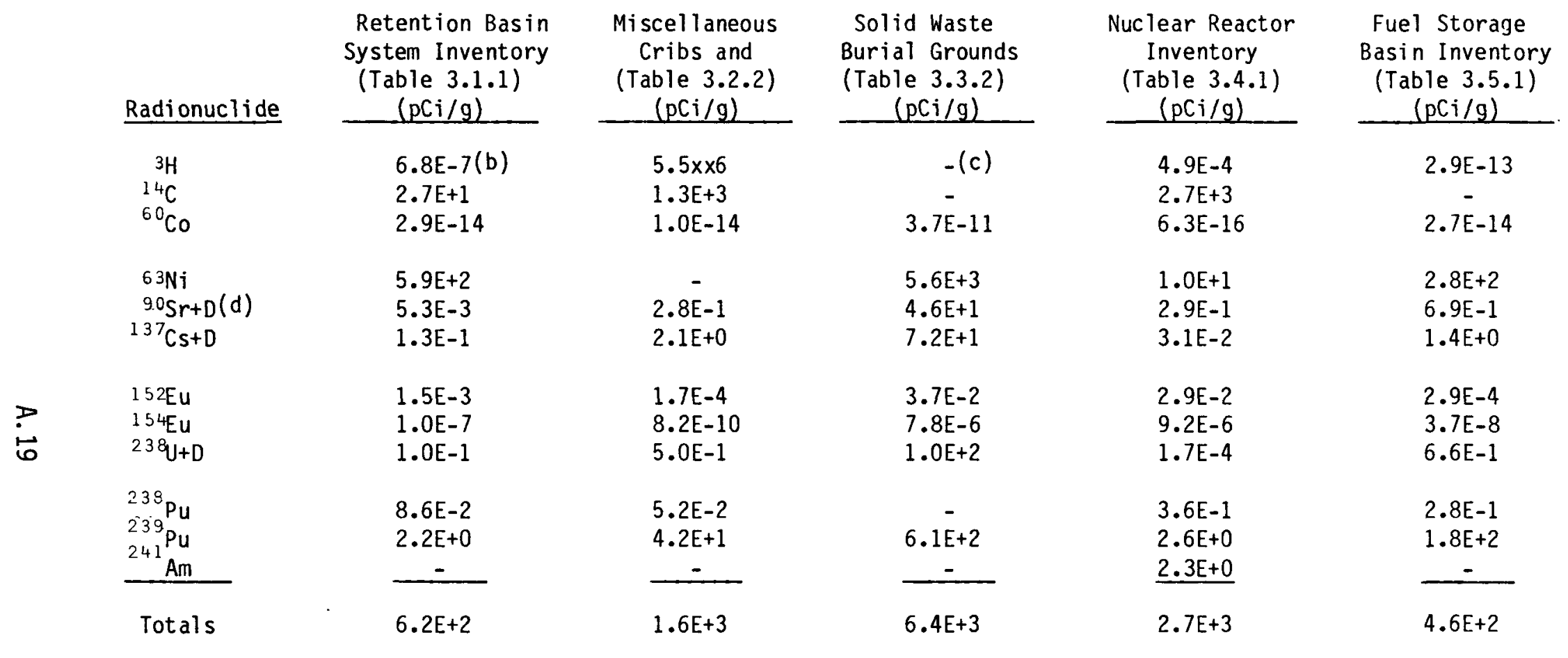

(a) Based on the residential/home-garden scenario (Section 4.0), the radionuclide inventories for each facility decayed 300 years and normalized to $1 \mathrm{pCi} / \mathrm{g}$ (Section 3.0), and an annual dose limit of $0.01 \mathrm{rem}$.

(b) Where $6.8 \mathrm{E}-7=6.8 \times 10^{-7}$.

(c) A dash indicates that the radionuclide shown is not considered in the radionuclide inventory shown.

(d) $+D$ means plus short-lived daughters. 
TABLE A.19. Allowable Residual Contamination Level Values for Decommissioned Facilities in the 100 Areas of the Hanford Sjte - Confined Soil at Depths Between 1 and 4 at $T=100$ Years $(a)$

\begin{tabular}{|c|c|c|c|c|c|}
\hline Radionuclide & $\begin{array}{c}\text { Retention Basin } \\
\text { System Inventory } \\
\text { (Table } 3.1 .1) \\
(\mathrm{pC} i / \mathrm{g}) \\
\end{array}$ & $\begin{array}{c}\text { Miscel l aneous } \\
\text { Cribs and } \\
\text { (Table } 3.2 .2) \\
(\mathrm{pCi} / \mathrm{g}) \\
\end{array}$ & $\begin{array}{l}\text { Solid Waste } \\
\text { Burial Grounds } \\
\text { (Table } 3.3 .2) \\
\quad(\mathrm{pCi} / \mathrm{g} \\
\end{array}$ & $\begin{array}{c}\text { Nuclear Reactor } \\
\text { Inventory } \\
\text { (Table 3.4.1) } \\
(\mathrm{pCi} / \mathrm{g}) \\
\end{array}$ & $\begin{array}{c}\text { Fuel Storage } \\
\text { Basin Inventory } \\
\text { (Table } 3.5 .1) \\
(\mathrm{pCi} / \mathrm{g}) \\
\end{array}$ \\
\hline $\begin{array}{l}{ }^{3 \mathrm{H}} \\
{ }^{14} \mathrm{C} \\
{ }^{60} \mathrm{Co}\end{array}$ & $\begin{array}{l}1.1 E-2(b) \\
8.0 E+0 \\
9.0 E-5\end{array}$ & $\begin{array}{l}1.1 E-2 \\
4.5 E+1 \\
1.0 E-4\end{array}$ & $\begin{array}{c}-(c) \\
8.0 E-2 \\
-\end{array}$ & $\begin{array}{l}9.5 E-1 \\
9.5 E+1 \\
5.5 E-6\end{array}$ & $\begin{array}{c}3.4 \mathrm{E}-10 \\
- \\
1.4 \mathrm{E}-4\end{array}$ \\
\hline $\begin{array}{l}63 \mathrm{Ni} \\
90 \mathrm{Sr}+\mathrm{D}(\mathrm{d}) \\
{ }^{137} \mathrm{Cs}+\mathrm{D}\end{array}$ & $\begin{array}{l}6.0 E+2 \\
2.2 E-1 \\
3.6 E-1\end{array}$ & $\begin{array}{c}- \\
1.4 \mathrm{E}+0 \\
6.7 \mathrm{E}+0\end{array}$ & $\begin{array}{l}1.9 E+2 \\
6.5 E+1 \\
5.5 E+1\end{array}$ & $\begin{array}{l}1.4 E+0 \\
1.6 E+0 \\
1.0 E-1\end{array}$ & $\begin{array}{l}2.3 E+1 \\
2.2 E+0 \\
2.9 E+0\end{array}$ \\
\hline $\begin{array}{l}152 \mathrm{Eu} \\
154 \mathrm{Eu} \\
238 \mathrm{U}+\mathrm{D}\end{array}$ & $\begin{array}{l}1.2 E+1 \\
2.7 E-1 \\
2.7 E-2\end{array}$ & $\begin{array}{l}1.4 \mathrm{E}-1 \\
2.5 \mathrm{E}-4 \\
1.6 \mathrm{E}-2\end{array}$ & $\begin{array}{l}2.4 E+1 \\
6.0 E-1 \\
8.0 E-1\end{array}$ & $\begin{array}{l}1.5 \mathrm{E}-1 \\
8.5 \mathrm{E}-3 \\
5.5 \mathrm{E}-6\end{array}$ & $\begin{array}{l}1.7 E-1 \\
7.0 E-3 \\
1.4 E-2\end{array}$ \\
\hline $\begin{array}{l}{ }_{238}^{23} \mathrm{Pu} \\
239 \mathrm{Pu} \\
{ }^{241} \mathrm{Pm} \\
\end{array}$ & $\begin{array}{c}1.2 \mathrm{E}-1 \\
5.5 \mathrm{E}-1 \\
-\end{array}$ & $\begin{array}{c}5.4 \mathrm{E}-3 \\
1.4 \mathrm{E}+0 \\
- \\
\end{array}$ & $\begin{array}{c}- \\
4.8 \mathrm{E}+0 \\
- \\
\end{array}$ & $\begin{array}{l}1.0 \mathrm{E}-1 \\
8.5 \mathrm{E}-2 \\
1.0 \mathrm{E}-1 \\
\end{array}$ & $\begin{array}{l}2.8 \mathrm{E}-2 \\
3.7 \mathrm{E}+0 \\
- \\
\end{array}$ \\
\hline Totals & $6.2 E+2$ & $5.5 E+1$ & $3.4 E+2$ & $9.9 E+1$ & $3.2 E+1$ \\
\hline
\end{tabular}

(a) Based on the residential/construction and residential/home-garden scenarios (Section 4.0), the radionuclide inventories for each facility (Section 3.0), and an annual dose limit of $0.01 \mathrm{rem}$.

(b) Where $1.1 \mathrm{E}-2=1.1 \times 10^{-2}$.

(c) A dash indicates that the radionuclide shown is not considered in the radionuclide inventory shown.

(d) $+D$ means plus short-lived daughters. 
TABLE A.20. Allowable Residual Contamination Level Values for Decommissioned Facilities in the 100 Areas of the Hanford Sjte - Confined Soil at Depths BEtween 1 and $4 \mathrm{~m}$ at $\mathrm{T}=300$ Years $(\mathrm{a})$

\begin{tabular}{|c|c|c|c|c|c|}
\hline Radionuclide & $\begin{array}{c}\text { Retention Basin } \\
\text { System Inventory } \\
\text { (Table } 3.1 .1) \\
(\mathrm{pC} i / g) \\
\end{array}$ & $\begin{array}{c}\text { Miscell laneous } \\
\text { Cribs and } \\
\text { (Table } 3.2 .2) \\
(\mathrm{pC} i / g)\end{array}$ & $\begin{array}{c}\text { Solid Waste } \\
\text { Burial Grounds } \\
\text { (Table } 3.3 .2) \\
\text { (pCi/g) } \\
\end{array}$ & $\begin{array}{c}\text { Nuclear Reactor } \\
\text { Inventory } \\
\text { (Table } 3.4 .1) \\
(\mathrm{pCi} / \mathrm{g}) \\
\end{array}$ & $\begin{array}{c}\text { Fuel Storage } \\
\text { Basin Inventory } \\
\text { (Table } 3.5 .1) \\
(\mathrm{pC} \mathrm{i} / \mathrm{g}) \\
\end{array}$ \\
\hline $\begin{array}{l}{ }^{3} \mathrm{H} \\
{ }^{14}{ }^{60} \\
{ }^{60} \mathrm{Co}\end{array}$ & $\begin{array}{l}3.4 \mathrm{E}-6(\mathrm{~b}) \\
1.4 \mathrm{E}+2 \\
1.4 \mathrm{E}-13\end{array}$ & $\begin{array}{l}2.8 E-5 \\
6.5 E+3 \\
5.2 E-14\end{array}$ & $\begin{array}{c}-(c) \\
- \\
1.8 E-10\end{array}$ & $\begin{array}{l}2.4 E-3 \\
1.4 E+4 \\
3.2 E-15\end{array}$ & $\begin{array}{c}1.2 E-12 \\
- \\
1.2 E-13\end{array}$ \\
\hline $\begin{array}{c}{ }^{63} \mathrm{Ni} \\
{ }_{90} \mathrm{Ni} \\
137 \mathrm{Sr}+\mathrm{D}(\mathrm{d}) \\
\mathrm{Cs}+\mathrm{D}\end{array}$ & $\begin{array}{l}3.0 \mathrm{E}+3 \\
2.6 \mathrm{E}-2 \\
6.5 \mathrm{E}-1\end{array}$ & $\begin{array}{c}- \\
1.4 E+0 \\
1.0 E+1\end{array}$ & $\begin{array}{l}2.8 E+4 \\
2.3 E+2 \\
3.6 E+2\end{array}$ & $\begin{array}{l}5.0 E+1 \\
1.4 E+0 \\
1.6 E-1\end{array}$ & $\begin{array}{l}1.2 E+3 \\
2.9 E+0 \\
6.0 E+0\end{array}$ \\
\hline $\begin{array}{l}{ }^{152} E u \\
154 \quad \\
238 U U \\
{ }_{U+D}\end{array}$ & $\begin{array}{l}7.5 E-3 \\
5.0 E-7 \\
5.0 E-1\end{array}$ & $\begin{array}{l}8.23 E-4 \\
4.1 E-9 \\
2.4 E+0\end{array}$ & $\begin{array}{l}1.8 E-1 \\
3.9 E-5 \\
5.0 E+2\end{array}$ & $\begin{array}{l}1.4 \mathrm{E}-1 \\
4.6 \mathrm{E}-5 \\
8.5 \mathrm{E}-4\end{array}$ & $\begin{array}{l}1.2 \mathrm{E}-3 \\
1.6 \mathrm{E}-7 \\
2.8 \mathrm{E}+0\end{array}$ \\
\hline $\begin{array}{l}238 \mathrm{Pu} \\
239 \mathrm{Pu} \\
241 \mathrm{Am}\end{array}$ & $\begin{array}{c}4.3 E-1 \\
1.1 E+1 \\
-\end{array}$ & $\begin{array}{r}2.6 E+1 \\
2.1 E+2 \\
-\end{array}$ & $\begin{array}{c}- \\
3.0 \mathrm{E}-11 \\
-\end{array}$ & $\begin{array}{l}1.8 \mathrm{E}+0 \\
1.3 \mathrm{E}+1 \\
1.2 \mathrm{E}+1 \\
\end{array}$ & $\begin{array}{c}1.2 \mathrm{E}+0 \\
7.8 \mathrm{E}+2 \\
- \\
\end{array}$ \\
\hline Totals & $3.2 E+3$ & $6.8 E+3$ & $3.0 E+4$ & $1.4 E+4$ & $2.0 \mathrm{E}+3$ \\
\hline
\end{tabular}

(a) Based on the residential/construction and residential/home-garden scenarios (Section 4.0), the radionuclide inventories for each facility (Section 3.0), and an annual dose limit of 0.01 rem.

(b) Where $3.4 \mathrm{E}-6=3.4 \times 10^{-6}$.

(c) A dash indicates that the radionuclide shown is not considered in the radionuclide inventory shown.

(d) $+D$ means plus short-lived daughters. 
TABLE A.21. Allowable Residual Contamination Level Values for Decommissioned Facilities in the 100 Areas of the Hanford Site - Confined Soil at Depths $\geq 5 \mathrm{~m}$ at $\mathrm{T}=100$ Years $(\mathrm{a})$

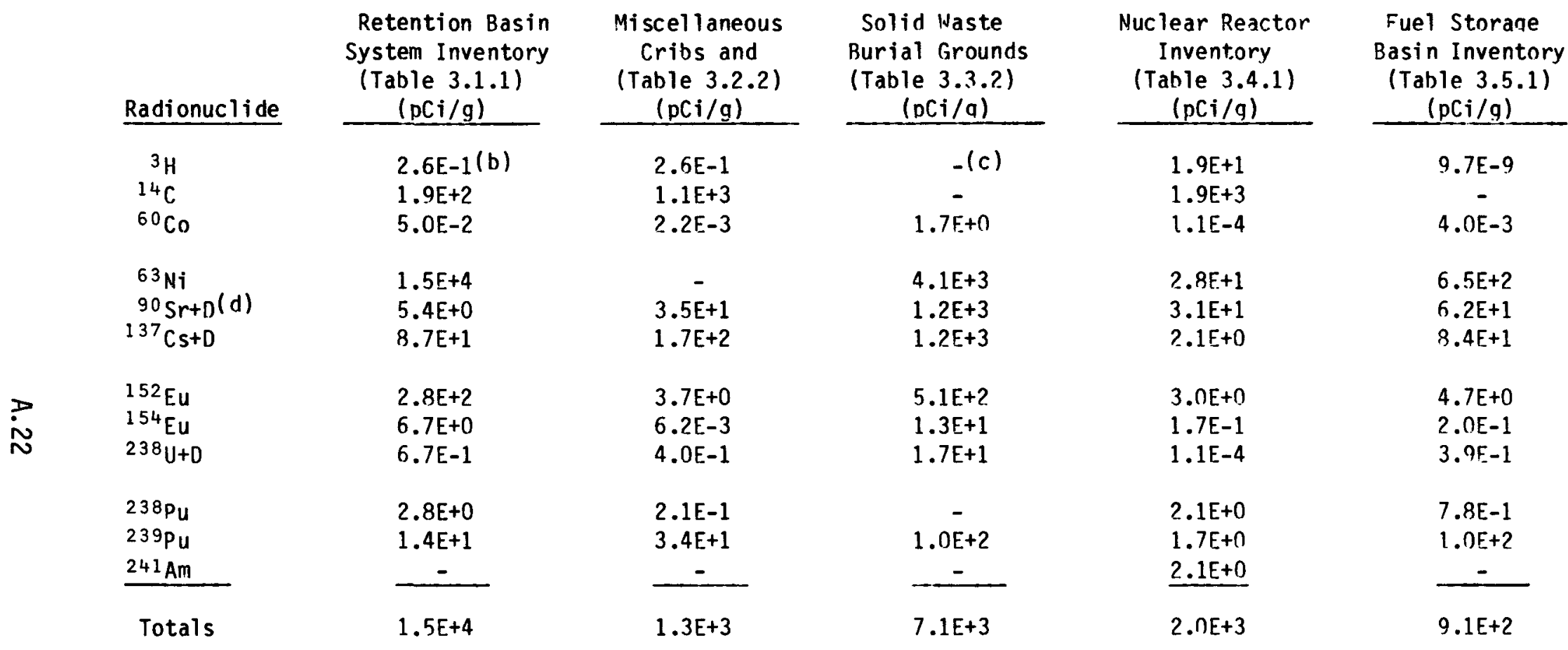

(a) Based on the residential/hone-garden scenario with a root penentration factor of $1 \%$ (Section 4.0 ), the radionuclide inventories for eacil facility (Section 3.0), and an annual dose limit of 0.01 rem.

(b) Where $2.6 \mathrm{E}-1=2.6 \times 10^{-1}$.

(c) A dash indicates that the radionuclide shown is not considered in the radionuclide inventory shown.

(d) $+D$ means plus short-lived daughters. 
TABLE A.22. Allowable Residual Contamination Level Values for Decommissioned Facilities in the 100 Areas of the Hanford Site - Confined Soil at Depths $\geq 5 \mathrm{~m}$ at $T=300$ Years $(\mathrm{a})$

\begin{tabular}{|c|c|c|c|c|c|}
\hline Radionuclide & $\begin{array}{l}\text { Retention Basin } \\
\text { System Inventory } \\
\text { (Table 3.1.1) } \\
\text { (pCi/g) }\end{array}$ & $\begin{array}{c}\text { Miscell laneous } \\
\text { Cribs and } \\
\text { (Table } 3.2 .2) \\
\text { (nCi/g) }\end{array}$ & $\begin{array}{l}\text { Solid Waste } \\
\text { Burial Grounds } \\
\text { (Table } 3.3 .2) \\
\quad(\mathrm{pC} \mathrm{i} / \mathrm{g}) \\
\end{array}$ & $\begin{array}{c}\text { Nuclear Reactor } \\
\text { Inventorv } \\
\text { (Table } 3.4 .1) \\
(\mathrm{pC} \mathrm{i} / \mathrm{g}) \\
\end{array}$ & $\begin{array}{c}\text { Fuel Storage } \\
\text { 3asin Inventory } \\
\text { (Table } 3.5 .1) \\
(\mathrm{pC} i / \mathrm{q}) \\
\end{array}$ \\
\hline $\begin{array}{l}{ }^{3} \mathrm{H} \\
{ }^{14} \mathrm{C} \\
{ }^{60} \mathrm{Co}\end{array}$ & $\begin{array}{l}7.3 E-5(b) \\
2.9 E+3 \\
3.1 E-12\end{array}$ & $\begin{array}{l}8.2 E-4 \\
2.0 E+5 \\
1.5 E-12\end{array}$ & $\begin{array}{c}-(c) \\
-7 E-9\end{array}$ & $\begin{array}{l}4.9 E-2 \\
2.7 E+5 \\
6.3 E-14\end{array}$ & $\begin{array}{c}3.3 E-1 \\
- \\
3.1 E-12\end{array}$ \\
\hline $\begin{array}{l}{ }^{63} \mathrm{Ni} \\
{ }^{90} \mathrm{Sr+D}(d) \\
13^{37} \mathrm{Cs}+\mathrm{D}\end{array}$ & $\begin{array}{l}6.3 \mathrm{E}+4 \\
5.6 \mathrm{E}-1 \\
1.4 \mathrm{E}+1\end{array}$ & $\begin{array}{c}- \\
4.2 E+1 \\
3.1 E+2\end{array}$ & $\begin{array}{l}5.6 E+5 \\
4.6 E+3 \\
7.2 E+3\end{array}$ & $\begin{array}{l}1.0 E+3 \\
2.9 E+1 \\
3.1 E+0\end{array}$ & $\begin{array}{l}3.2 \mathrm{E}+4 \\
7.9 \mathrm{E}+1 \\
1.7 \mathrm{E}+2\end{array}$ \\
\hline $\begin{array}{l}15^{52} \mathrm{Eu} \\
15^{4} \mathrm{Eu} \\
23^{8} \mathrm{U}+\mathrm{D}\end{array}$ & $\begin{array}{l}1.6 \mathrm{E}-1 \\
1.1 \mathrm{E}-5 \\
1.1 \mathrm{E}+1\end{array}$ & $\begin{array}{l}2.5 \mathrm{E}-2 \\
1.2 \mathrm{E}-7 \\
7.5 \mathrm{E}+1\end{array}$ & $\begin{array}{l}3.7 E+0 \\
7.8 E-4 \\
1.0 E+4\end{array}$ & $\begin{array}{l}2.9 E+0 \\
9.3 E-4 \\
1.7 E-2\end{array}$ & $\begin{array}{l}1.7 \mathrm{E}+2 \\
4.2 \mathrm{E}-6 \\
7.7 \mathrm{E}+1\end{array}$ \\
\hline $\begin{array}{l}238 \mathrm{Pu} \\
239 \mathrm{Pu} \\
241_{\mathrm{Am}}\end{array}$ & $\begin{array}{c}9.2 \mathrm{E}+0 \\
2.3 \mathrm{E}+2 \\
-\end{array}$ & $\begin{array}{c}7.8 E+0 \\
6.3 E+3 \\
-\end{array}$ & $\begin{array}{c}- \\
6.1 E+4 \\
-\end{array}$ & $\begin{array}{l}3.6 E+1 \\
2.6 E+2 \\
2.3 E+2\end{array}$ & $\begin{array}{l}\text { 3. } 2 E+1 \\
2.0 E+4 \\
-\end{array}$ \\
\hline Totals & $6.6 \mathrm{E}+4$ & $2.1 E+5$ & $6.5 F+5$ & $2.7 E+5$ & $5.3 E+4$ \\
\hline
\end{tabular}

(a) Based on the residential/home-garden scenario with a root penetration factor of $1 \%$ (Section 4.0 ), the radionuclide inventories for each facility (Section 3.0), and an annual dose limit of $0.01 \mathrm{rem}$.

(b) Where $7.3 \mathrm{E}-5=7.3 \times 10^{-5}$.

(c) A dash indicates that the radionuclide shown is not considered in the radionuclide inventory shown.

(d) $+D$ means plus short-lived daughters. 
APPENDIX B

ALLOWABLE RESIDUAL CONTAMINATION LEVEL WORKSHEETS FOR FACILITIES IN THE 100 AREAS OF THE HANFORD SITE 
APPENDIX B

ALLOWABLE RESIDUAL CONTAMINATION LEVEL WORKSHEETS FOR FACILITIES IN THE 100 AREAS OF THE HANFORD SITE

The ARCL method permits the consideration of mixtures and concentrations of radionuclides different than the representative inventories considered in this report. Figure B.1 contains a worksheet that can be used to determine the $A R C L$ resulting for any combination of the radionuclides shown in Table 5.2.2. The following instructions explain how to use the work sheet.

1. Facility Name. Enter the name or the numerical designation of the facility and other identification information.

2. Preparer's Name. Enter the name of the person preparing the ARCL worksheet.

3. Date. Enter the date on which the worksheet was completed.

4. Determination of ARCL Dose Factors to Enter from Table 5.2.2. The calculation requires the proper dose factors which are a function of both the use mode and the contamination condition. Check only one use mode and only one contamination condition to uniquely determine from the worksheet which column of Table 5.2.2 contains the proper factors. Use Mode Considered. Check the use mode considered (i.e., restricted, controlled, or unrestricted). Note that the annual dose limits considered are $0.5 \mathrm{rem} / \mathrm{yr}$ for restricted and controlled use, and $0.01 \mathrm{rem} / \mathrm{yr}$ for unrestricted use. If results for more than one use mode are desired, additional work sheets should be used.

Contamination Conditions. Select either surface contamination (in $\mathrm{Ci} / \mathrm{m}^{2}$ ) or soil contamination (in $\mathrm{pCi} / \mathrm{g}$ ) calculations. Note that the soil contamination calculations can consider unconfined (surface) soil or confined (subsurface) soil conditions. Facility surface contamination calculations $\left(\mathrm{Ci} / \mathrm{m}^{2}\right)$ require factors from Columns 1,2 , or 3 of

B. 1 
1. Facility Name:

2. Preparer's Name:

3. Date Prepared:

4. Determination of ARCL Dose Factors to Enter From Table 5.2.2. Check one Use Mode and one Contamination Condition.

\begin{tabular}{|c|c|c|c|c|}
\hline Use Mode/Contamination Condition & $\begin{array}{l}\text { Contaminated Surfaces } \\
\mathrm{Ci} / \mathrm{m}^{2} \text { or } \mathrm{dpm} / 100 \mathrm{~cm}^{2}\end{array}$ & $\begin{array}{r}\text { Surface Soil } \\
(\mathrm{DC} i / \mathrm{q})\end{array}$ & $\begin{array}{c}\text { Soil } 1-4 \mathrm{~m} \text { Deeo } \\
\text { ( } \mathrm{DC} \mathrm{j} / \mathrm{g}) \\
\end{array}$ & $\begin{array}{c}\text { Soil } \geq 5 \mathrm{~m} \text { neep } \\
(\mathrm{DC} / \mathrm{g})\end{array}$ \\
\hline $\begin{array}{l}\text { Restricted Use } 00.5 \mathrm{rem} / \mathrm{yr} \\
\text { Controlled Use } 00.5 \mathrm{rem} / \mathrm{yr} \\
\text { Unrestricted Use } 00.01 \mathrm{rem} / \mathrm{yr}\end{array}$ & $\begin{array}{l}\text { Column } 1 \\
\text { Column } 2 \\
\text { Column } 3\end{array}$ & $\begin{array}{l}\text { Column } 4 \\
\text { Column } 4 \\
\text { Column } 4\end{array}$ & $\begin{array}{l}\text { Column } 5 \\
\text { Column } 5 \\
\text { Column } 5\end{array}$ & $\begin{array}{l}\text { Column } 6 \\
\text { Column } 6 \\
\text { Column } 6\end{array}$ \\
\hline
\end{tabular}

5. Radionuclides 6. Radionuclide

6a. Radionuclide*. 7. Scenario-Specific ARCL Dose Factors

8. Product of

9. $A R C L$ - Product

10. Conversion

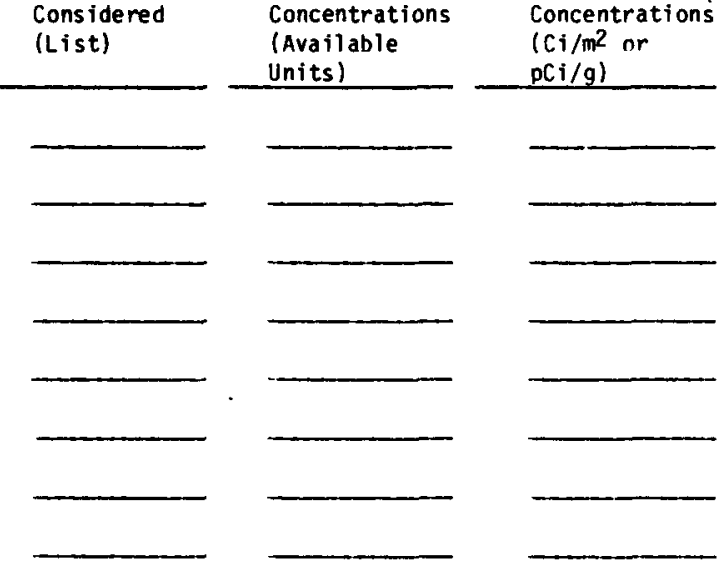
(Step 4; rem/yr per:

Columns 6a \& 7

of Column 6a

to $\mathrm{dpm} / 100 \mathrm{~cm}^{2}$ $\left[\mathrm{Ci} / \mathrm{m}^{2}\right.$ or $\left.\left.\mathrm{oC} i / \mathrm{q}\right]\right)$

(r)

olumn

5b. Total:

*May be taken from Decay

Correction Work sheet
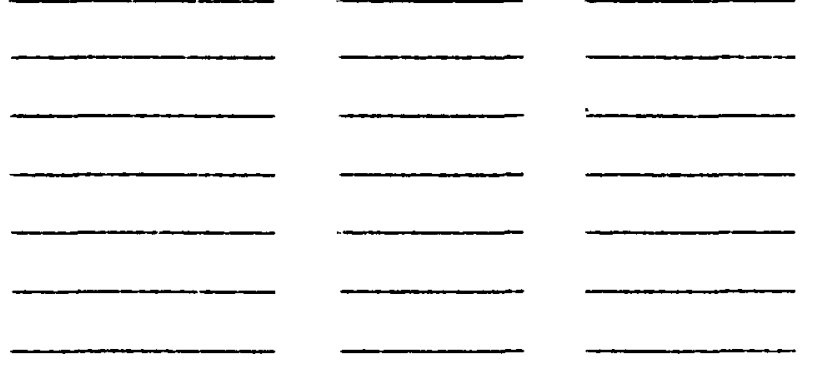

8a. Total: 9a. Total:
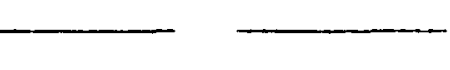

10a. Total:

9a. Divided by 6 .

$=0.5$ or $0.011=8 \mathrm{~b})=8 \mathrm{~b}$ ?

11. Present Gross Contamination Level Yielding Future ARCL of Item 9a: (Used only with Decay Correction Worksheet) Product of Item 9a (or 10a) and Item 9 of Decay Correction Worksheet.

(9a or 10a) $\times(9$ of Figure B.4) $=$

$\left(\mathrm{Ci} / \mathrm{m}^{2}, \mathrm{PC} \mathrm{i} / \mathrm{q}\right.$, or $\left.\mathrm{dpm} / 100 \mathrm{~cm}^{2}\right)$

12. Additional Notes.

FIGURE B.1. Allowable Residual Contamination Level Worksheet for Facilities at the Hanford Site 
Table 5.2.2, depending upon the use mode desired. Soil contamination calculations $(\mathrm{pCi} / \mathrm{g})$ require factors from Columns 4,5 , or 6 of Table 5.2.2, depending on whether unconfined or confined soil estimates are desired. If results for more than one contamination condition are required, additional worksheets should be used.

5. Radionuclides Considered. Enter the radionuclides considered in the space provided. If additional space is required, use additional work sheets.

6. Radionuclide Concentrations. The calculation requires that the source inventory be given in units of $\mathrm{Ci} / \mathrm{m}^{2}$ for surfaces or $\mathrm{pCi} / \mathrm{g}$ for soils. If the inventory is available in other units (such as $\mathrm{dpm} / 100 \mathrm{~cm}^{2}$ ), list it in worksheet Item 6 and convert to appropriate units in Item 6a. Total the results and enter in Item 6b. The inventory may be given in either relative or absolute amounts. To determine the effect of radioactive decay on the $A R C L$ value calculated for a mixture, a radioactive decay correction should be applied to the source inventory. This correction is outlined in a separate worksheet (Figure B.4). The resulting decayed inventory should then be entered in Item $6 a$ of Figure B.1, with the total reported in Item $6 b$.

7. Scenario-Specific ARCL Dose Factors. Enter the values from the appropriate column of Table 5.2.2 (as determined in Step 4) in units of $\mathrm{rem} / \mathrm{yr}$ per $\mathrm{Ci} / \mathrm{m}^{2}$ for surfaces or $\mathrm{rem} / \mathrm{yr}$ per $\mathrm{pCi} / \mathrm{g}$ for soils.

8. Product of Columns 6a and 7. Multiply the concentration of each radionuclide 1 isted in worksheet Item $6 \mathrm{a}$ by its corresponding scenario-specific ARCL dose factor from Item 7 and enter in units of $\mathrm{rem} / \mathrm{yr}$. Sum all radionuclides and enter the total as Item $8 \mathrm{a}$. Next, divide the annual dose limit (either 0.5 or $0.01 \mathrm{rem} / \mathrm{yr}$ ) by the total and enter the result as Item $8 b$. Note, a different dose limit may be substituted in this step if desired.

9. ARCL. Multiply the concentration of each radionuclide given in Item $6 \mathrm{a}$ by the correction factor of Item $8 \mathrm{~b}$ and enter the corresponding ARCL values for each nuclide of the specific mixture in 
Item 9 in units of $\mathrm{Ci} / \mathrm{m}^{2}$ or $\mathrm{pCi} / \mathrm{g}$. Sum all entries in the column and enter the total mixture ARCL as Item 9a. The value calculated as Item $9 \mathrm{a}$ is the total gross activity that may be allowed to remain that results in the desired dose limit. At this point, a convenient mathematical check may be made by dividing Item 9 a by Item $6 a$; the result should be equal to Item $8 b$.

10. Conversion From $\mathrm{Ci} / \mathrm{m}^{2}$ to $\mathrm{dpm} / 100 \mathrm{~cm} 2$. If facility surface contamination calculations are desired, the result is converted from $\mathrm{Ci} / \mathrm{m}^{2}$ by multiplying the ARCL values for each radionuclide (Item 9 ) by a constant $2.2 \times 1010$. Enter the results in units of dpm/100 cm2 in Item 10. Note: This step should not be performed if soil contamination calculations are desired. A value corresponding to Item 9a may be calculated either as the sum of the values in Item 10 or a multiple of Item $9 \mathrm{a}$ and entered as Item 10a.

11. Optional Decay-Time Correction. If the radionuclide concentrations used in Items 6 or 6 a were taken from the Radioactive Decay Correction Worksheet (Figure B.4), then the result calculated as Item 9a (or Item 10a) of the ARCL Worksheet (Figure B.1) is the ARCL applicable to that future time. That is, it is the amount that may remain on the surface or in the soil at the future time of unrestricted release. To determine the present contamination level of the nuclide mixture that will result in the limiting dose at the future time, one additional step is necessary. Multiply the value of Item 9a (or Item 10a, if calculated) by the value of Item 9 of the Decay-Time Correction Work sheet.

12. Additional Notes. Add any additional comments or clarifications on the worksheet.

As examples of the use of the ARCL worksheet, two sample problems are described. Both rely on a radionuclide mixture composed of ${ }^{14} \mathrm{C}(70 \%), 63 \mathrm{Ni}$ $(5 \%),{ }^{90} \mathrm{Sr}+\mathrm{D}(7 \%),{ }^{137} \mathrm{Cs}+\mathrm{D}(8 \%)$, and ${ }^{152 \mathrm{Eu}}(10 \%)$ by activity. The completed worksheet for the first sample problem, unrestricted release of a facility with surface contamination, is shown in Figure B.2. The relative 
1. Facility Name: Example Problem 1 - unrestricted Use of a Facility

2. Preparer's Name: $W . E, K \in N N E D_{Y}, J_{R}$.

3. Date Prepared: $6 / 30 / 83$

4. Determination of ARCL Dose Factors to Enter From Table 5.2.2. Check one Use Mode and one Contamination Condition.

\begin{tabular}{|c|c|c|c|c|c|}
\hline Use Mode/Contamination Condition & $\begin{array}{l}\text { Contaminated Surfaces } \\
\mathrm{ci} / \mathrm{m}^{2} \text { or } \mathrm{dpm} / 100 \mathrm{~cm}^{2}\end{array}$ & $\checkmark$ & $\begin{array}{r}\text { Surface Soil } \\
(0 C i / q)\end{array}$ & $\begin{array}{c}\text { Soil } 1-4 \mathrm{~m} \text { neen } \\
\text { (DC } \mathrm{p} / \mathrm{g})\end{array}$ & $\begin{array}{c}\text { Soil } \geq 5 \mathrm{~m} \text { Deep } \\
(\mathrm{pC} i / q)\end{array}$ \\
\hline $\begin{array}{l}\text { Restricted Use } 00.5 \mathrm{rem} / \mathrm{yr} \\
\text { Controlled Use } 00.5 \mathrm{rem} / \mathrm{yr} \\
\text { Unrestricted Use } 00.01 \mathrm{rem} / \mathrm{yr}\end{array}$ & $\begin{array}{l}\text { Column } 1 \\
\text { Column } 2 \\
\text { Column } 3 \\
\end{array}$ & 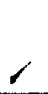 & $\begin{array}{l}\text { Column } 4 \\
\text { Column } 4 \\
\text { Column } 4\end{array}$ & $\begin{array}{l}\text { Column } 5 \\
\text { Column } 5 \\
\text { Column } 5\end{array}$ & $\begin{array}{l}\text { Column } 6 \\
\text { Column } 6 \\
\text { Column } 6\end{array}$ \\
\hline
\end{tabular}

- Scenario-Specific Considered

(List)

ש

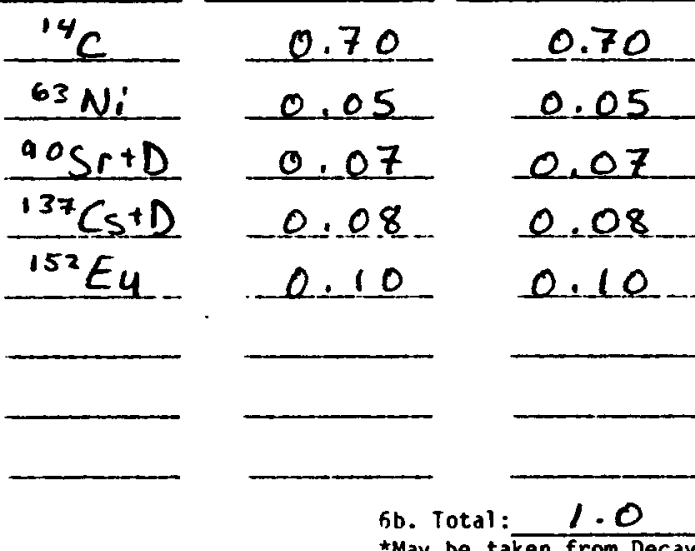

$$
\begin{aligned}
& \text { * May be taken from Decay }
\end{aligned}
$$

ARCL Dose Factors

8. Product of

9. $A R C L$ - Product of Column 6a \&

10. Conversion [Ci/m² (rem/yr) (ci/m Multiply Column 9

Correction Work sheet

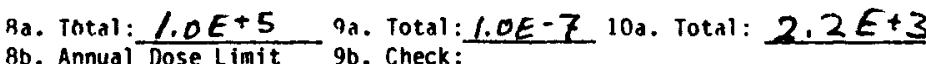

$9 \mathrm{a}$. Divided by $6 \mathrm{~b}$

$(0.50 .01 / 1.0 E+5) \quad(1.0 E-7 \div 1.0)$

$=1.0 E-7=80=1.0 E-7=8 \mathrm{~b}$ ?

11. Present Gross Contamination Level Yielding Future ARCL of Item 9a: (Used oniy with Decay Correction Worksheet)

(9a or 10a) $N A^{2} \times(9$ of Figure $B .4) \sim N A=N A\left(\mathrm{Ni} / \mathrm{m}^{2}, \mathrm{PCi} / \mathrm{a}\right.$, or $\left.\mathrm{dpm} / 100 \mathrm{~cm}^{2}\right)$

12. Addi tional Notes.

FIGURE B.2. Allowable Residual Contamination Level Worksheet for Facilities at the Hanford Site - Example Problem 1 
concentrations of the radionuclides are shown as worksheet Item 6 , and al so as Item 6a (because the absolute magnitude of the inventory is not important, only the activity distribution), with the total reported in Item $6 \mathrm{~b}$ in units of $\mathrm{Ci} / \mathrm{m}^{2}$. Scenario-specific ARCL dose factors for the radionuclides, obtained from Column 3 of Table 5.2.2 (as indicated by Item 4 of the worksheet) are listed in worksheet Item 7 . The products of the entries in Items $6 a$ and 7 are 1 isted in Item 8 , with the cumulative total of $1.0 \times 10^{5} \mathrm{rem} / \mathrm{yr}$ given as Item $8 \mathrm{a}$. This value is the dose that a potential resource salvager could receive if the facility were left contaminated to the level of Item $6 \mathrm{~b}, 1.0 \mathrm{Ci} / \mathrm{m}^{2}$. The ratio of the unrestricted release annual dose limit $(0.01$ rem) to the total in Item 8 a is given in Item $8 b$ as $1.0 \times 10^{-7}$. This value, multiplied by the entries in Item $6 a$, results in the ARCL values of Item 9. These individual radionuclide values sum to the $A R C L$ for the mixture of $1.0 \times 10-7 \mathrm{Ci} / \mathrm{m}^{2}$, Item 9a. The mathematic check of Item $9 b$ indicates that no errors were propagated into the example. Finally, since surface contamination calculations are being performed, the conversion of the result to units of $\mathrm{dpm} / 100 \mathrm{~cm} 2$ is performed in Item 10 . The total, $2200 \mathrm{dpm} / 100 \mathrm{~cm} 2$, is reported as Item $10 \mathrm{a}$.

The second sample problem considers the same radionuclides and concentration (now in $\mathrm{pCi} / \mathrm{g}$ ) for unrestricted use of unconfined surface soil as shown by Items 4 through 7 of Figure B.3. The scenario-specific ARCL dose factors for this sample problem are obtained from Column 4 of Table 5.2.2 and entered in Item 7 . The products of the radionuclide concentrations and ARCL dose factors are reported in Item 8 , with a total of $8.4 \times 10^{-3} \mathrm{rem} / \mathrm{yr}$ shown in Item $8 \mathrm{a}$. The ratio of the annual dose limit $(0.01 \mathrm{rem})$ to Item $8 \mathrm{a}$ is shown in Item $8 \mathrm{~b}$ as 1.2 . The resulting $A R C L$ values are reported in Item 9 with the total of $1.2 \mathrm{pCi} / \mathrm{g}$.

The radionuclide contributing the dominant portion of the dose in both example problems is $90 \mathrm{~S} r+\mathrm{D}$. This can be seen by inspection of the entries in Item 8 of both examples; the largest dose contribution is the ${ }^{90} \mathrm{Sr}$, even though it is only $7 \%$ of the original mixtures. 
1. Facility Name: Example Proseen 2-Unrestricted Release of Surface Sod

2. Prenarer's Name: W.E.KENNESY, JR.

3. Date Preparen: $6 / 30 / 83$

4. Determination of ARCL Dose Factors to Enter From Table 5.2.2. Check one Use Mode and one Contamination Condition.

\begin{tabular}{|c|c|c|c|c|}
\hline Use Mode/Contamination Condition & $\begin{array}{l}\text { Contam inated Surfaces } \\
\mathrm{cl} / \mathrm{m}^{2} \text { or } \mathrm{dnm} / 100 \mathrm{~cm}^{2}\end{array}$ & $\begin{array}{r}\text { Surface Sonil } \\
\text { (nci } 1 / q)\end{array}$ & $\checkmark \begin{array}{c}\text { Soil } 1-4 \text { m Deen } \\
(0, i / q)\end{array}$ & $\begin{array}{c}\text { Soil } \geq 5 \text { m neep } \\
\text { (DCi/g) }\end{array}$ \\
\hline $\begin{array}{l}\text { Pestricted Use } 0.5 \mathrm{rem} / \mathrm{yr} \\
\text { Controlled Use } 0.5 \mathrm{rem} / \mathrm{yr} \\
\text { Unrestricted Use } 0.0 .01 \mathrm{rem} / \mathrm{yr}\end{array}$ & $\begin{array}{l}\text { Column } 1 \\
\text { Column } 2 \\
\text { Column } 3\end{array}$ & $\begin{array}{c}\text { Column } 4 \\
\text { Column } 4 \\
\text { Column } 4\end{array}$ & $\begin{array}{l}\text { Column } 5 \\
\text { Column } 5 \\
\text { Column } 5\end{array}$ & $\begin{array}{l}\text { Column } 6 \\
\text { Column } 6 \\
\text { Column } 6\end{array}$ \\
\hline
\end{tabular}

$$
\begin{aligned}
& \text { Radionuclide } \\
& \begin{array}{l}
\text { Concentrations } \\
\text { (Available }
\end{array} \\
& 0.70
\end{aligned}
$$

\begin{tabular}{|c|}
\hline${ }^{14} \mathrm{C}$ \\
\hline${ }^{63} N_{i}$ \\
\hline $905 r+0$ \\
\hline${ }^{137} C_{s}+D$ \\
\hline${ }^{152} E_{4}$ \\
\hline
\end{tabular}

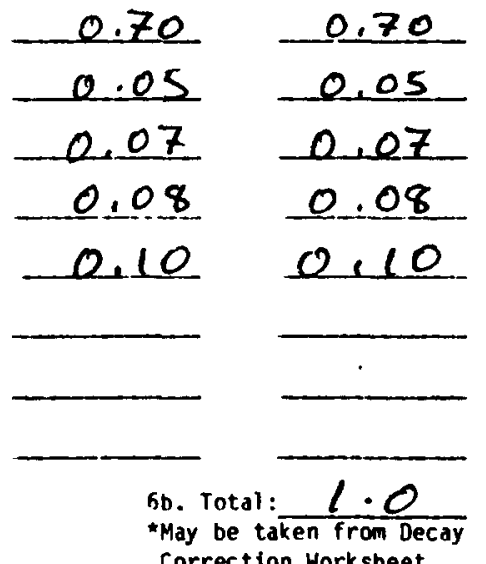

\section{* May be taken from Decay}

7. Scenario-Specific ARCL Dose Factors

A. Product of Columns 6a \& of Column $6 a \&$
$1+e m 8 b$ ( (rem/yr)

10. Conversion

$$
5.8 E-8
$$
$\left(\mathrm{Ci} / \mathrm{m}^{2}\right.$ ar $\mathrm{p}(\mathrm{i} / \mathrm{q})$ 8a. Total: $8.4 \epsilon-3$ 9a. Total: 1.2 10a. Total 8b. Annual Dose Limit 9b. Check: 9a. Divided by $6 b$. $=1.2 \frac{0.01 / 8.4 E-3)}{=80}=\frac{1.2}{1.2} \div \frac{1.01}{8 b}$ ?

11. Present Gross Contamination Level Yielding Future ARCL of Item 9a: (Used only with Decay Correction Worksheet) Product of Item 9 a (or 10a) and I tem 9 of Decay Correction Hork sheet.

(9a or 10a) NA $\times\left(9\right.$ of Figure B.4) NA $=N A\left(C i / \mathrm{m}^{2}, \mathrm{PCl} / \mathrm{a}\right.$, or $\left.\mathrm{dpm} / 100 \mathrm{~cm}^{2}\right)$

12. Addi tional Notes.

FIGURE B.3. Allowable Residual Contamination Level Worksheet for Facilities at the Hanford Site - Example Problem 2 
The entries in Item 6 or $6 \mathrm{a}$ of the worksheet are designed to be input as curies (or relative curies) existing on or at the site at the time of release. Thus, for restricted or controlled use, the input inventory is that presently existing on the site. However, unrestricted use can occur immediately, or at some time in the future at the end of restricted or controlled use. The radionuclide inventory would be decayed to some level lower than that existing today. The effect of radioactive decay on the source inventory for a mixture can be determined using the worksheet shown in Figure B.4. The decayed inventory resulting from the Figure B.4 Worksheet is then used in the Figure B.1 Worksheet to determine the ARCL value after radioactive decay. Decay periods of 100 years for restricted use and 300 years for control led use are used for this study, but any decay time (in years) can be used in the worksheet. The following instructions explain how to use the decay correction worksheet shown in Figure B.4.

1. Facility Name. Enter the name or numerical designation of the facility and any other identification information.

2. Preparer's Name. Enter the name of the person preparing the decay correction worksheet.

3. Date. Enter the date on which the worksheet was completed.

4. Radionuclides Considered. Enter the radionuclides considered in the space provided. If additional space is required, use additional work sheets.

5. Present Contamination Level. Enter the present source inventory in units of $\mathrm{Ci} / \mathrm{m}^{2}$ for surfaces or $\mathrm{pCi} / \mathrm{g}$ for soils. This inventory is the $T=0$ inventory and can be given in relative or absolute amounts.

6. Decay Constant. Enter the decay constant $\left(y r^{-1}\right)$ for each radionuclide in the source inventory. A list of decay constants is shown at the bottom of the worksheet.

7. Time in the Future. The number of years of radioactive decay considered should be entered in Item 7. Note: The same number of years should be entered for each radionuclide. 
1. Facility Name:

2. Preparer's Name:

3. Date:

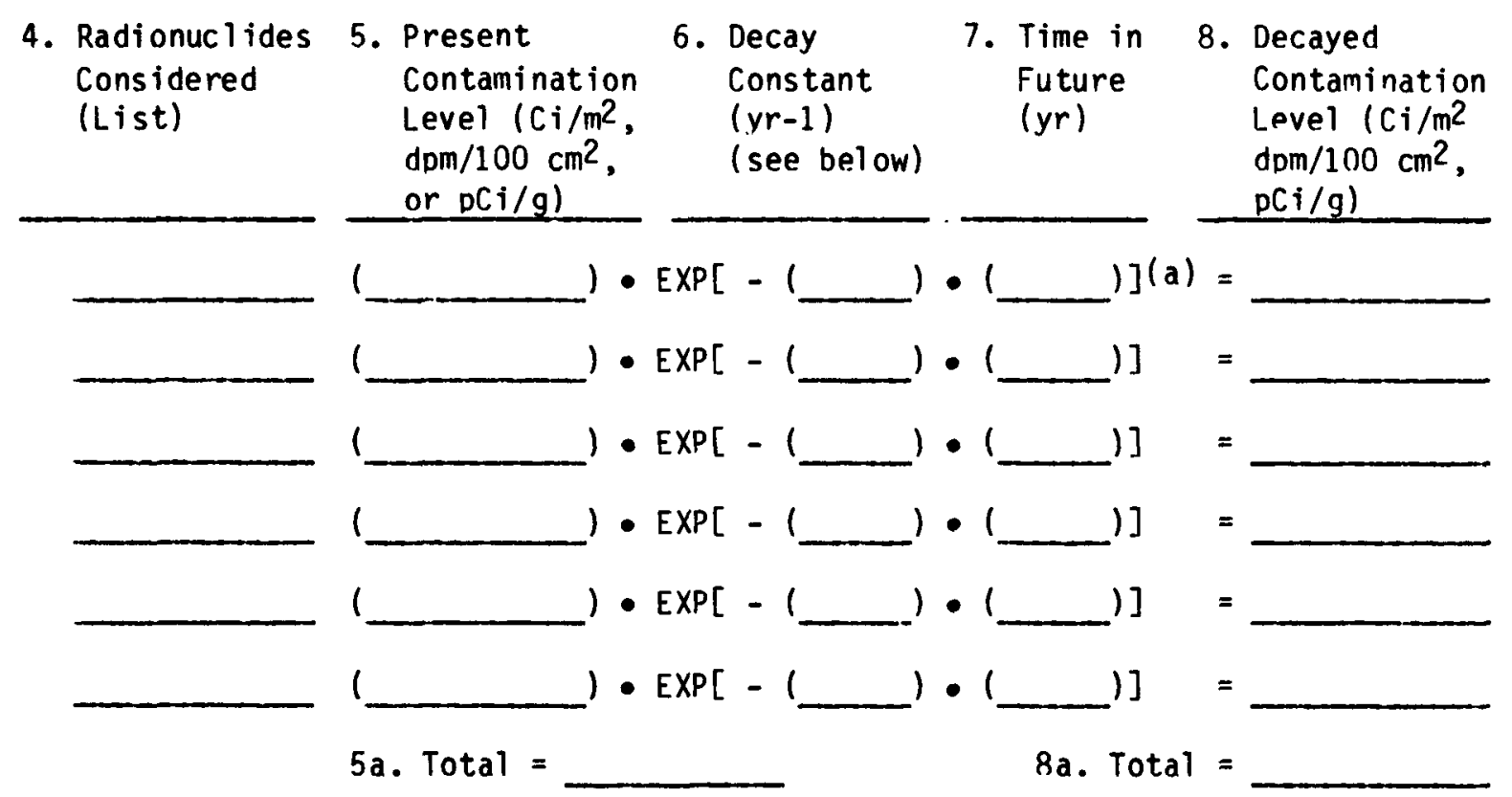

9a. Ratio of Present to Future Gross Contamination Levels. Quntient of Item 5a and Item 8a. 5a. (__ $8 \mathrm{a} \cdot\left({ }_{2}\right)=$

Decay Constants for Potential Nuclides at the 115-F and 117-F Facilities

Nuclide Constant Nuclide Constant Nuclide Constant Nuclide Constant

$\begin{array}{llllllll}{ }^{3} \mathrm{H} & 5.6 \mathrm{E}-2 & { }^{63} \mathrm{Ni} & 7.5 \mathrm{E}-3 & 135 \mathrm{Cs} & 3.0 \mathrm{E}-7 & 237 \mathrm{~Np}+\mathrm{D} & 3.2 \mathrm{E}-7 \\ { }^{14} \mathrm{C} & 1.2 \mathrm{E}-4 & 90 \mathrm{Sr}+\mathrm{D} & 2.4 \mathrm{E}-2 & 137 \mathrm{C}, \mathrm{s}+1 & 2.3 \mathrm{E}-2 & 238 \mathrm{Pu} & 7.9 \mathrm{E}-3 \\ { }^{57} \mathrm{Co} & 9.3 \mathrm{E}-1 & 93 \mathrm{MD} & 2.3 \mathrm{E}-4 & 144 \mathrm{Ce} & 8.9 \mathrm{E}-1 & 239 \mathrm{Pu} & 2.8 \mathrm{E}-5 \\ { }^{60} \mathrm{Co} & 1.3 \mathrm{E}-1 & { }^{99} \mathrm{TC} & 3.2 \mathrm{E}-6 & 152 \mathrm{Eu} & 5.0 \mathrm{E}-2 & 241 \mathrm{Am} & 1.6 \mathrm{E}-3 \\ { }^{55} \mathrm{Fe} & 2.6 \mathrm{E}-1 & 124 \mathrm{Sb} & 4.2 \mathrm{E}+0 & 154 \mathrm{Eu} & 8.9 \mathrm{E}-2 & & \\ { }^{59} \mathrm{Fe} & 5.6 \mathrm{E}+0 & 125 \mathrm{Sb}+\mathrm{D} & 2.5 \mathrm{E}-1 & 235 \mathrm{U}+\mathrm{D} & 9.8 \mathrm{E}-10 & & \\ { }^{59} \mathrm{Ni} & \mathbf{8 . 7 E}-6 & 134 \mathrm{Cs} & 3.4 \mathrm{E}-1 & 238 \mathrm{U}+\mathrm{D} & 1.5 \mathrm{E}-10 & & \end{array}$

(a) The notation EXP $[-(a)(b)]$ means the exponential, $e^{-a b}$

FIGURE B.4. Allowable Residual Contamination Level Radioactive Decay Correction Worksheet

B. 9 
8. Decayed Contamination Leve1. The negative exponential of the product of the entries in Items 6 and 7 times the entries in Item 5 is reported in Item 8 as the decayed contamination level. This level should be totaled in Item $8 \mathrm{a}$ and entered in the ARCL Worksheet (Figure B.1) to determine the decayed ARCL value for the specific time in the future considered.

As an example of this procedure, the soil contamination inventory of Example Problem 2 is used in the Decay Worksheet with an assumed decay period of 300 years. Figure B.5 shows the resulting decay calculations as Example Problem 3. The decayed contamination level for the mixture is $0.685 \mathrm{pCi} / \mathrm{g}$ in soil. This decayed contamination level is used in the ARCL Worksheet to determine the unrestricted ARCL value for the soil contamination example problem after 300 years of controlled use. The resulting calculations are shown in Figure B.6 as a continuation of Example Problem 3.

The impact of radioactive decay on the ARCL calculations can be demonstrated by comparing the ARCL results for Example Problems 2 and 3 (see Figures $B .3$ and B.6). At $T=0$, the ARCL value is controlled by $90 \mathrm{~S} r+\mathrm{D}$, but after 300 years of radioactive decay, the ARCL value is influenced by the longer-lived $63 \mathrm{Ni}$. Since the scenario-specific ARCL dose factor for $63_{\mathrm{Ni}}$ is less than the one for ${ }^{90} \mathrm{~S}+\mathrm{D}$, a higher contamination level can be permitted. Thus, the ARCL for the mixture at $T=0$ is $1.2 \mathrm{pCi} / \mathrm{g}$, while at $T=300$ the value is $786 \mathrm{pCi} / \mathrm{g}$. The presently allowable contamination level that will result in $786 \mathrm{pCi} / \mathrm{g}$ in 300 years is $1150 \mathrm{pCi} / \mathrm{g}$.

The instrument response for the ARCL with field or laboratory equipment can be determined using the Instrument Response Worksheet shown in Figure B.7. The following instructions explain how to use This work sheet.

1. Facility Name. Enter the name or numerical designation of the facility and any other identification information.

2. Preparer's Name. Enter the name of the person preparing the Instrument Response Work sheet. 
1. Facility Name: Example Proslem 3-Correction for 300 years of Radioactive Decay - Unrestricted Release of Surface Soll

2. Preparer's Name: $W . \varepsilon$. Kennedy, JR.

3. Date: $6 / 30 / 83$

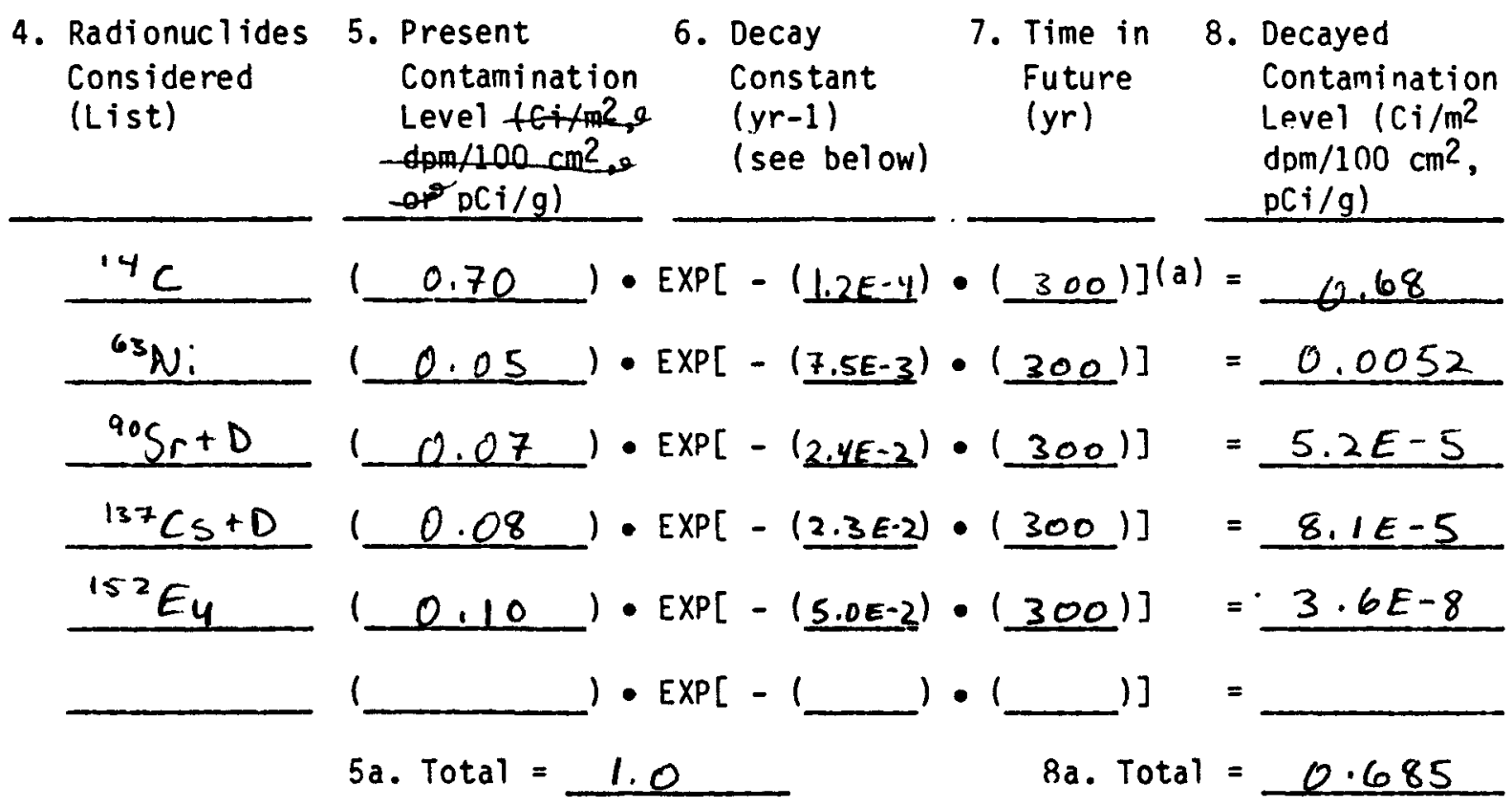

9a. Ratio of Present to Future Gross Contamination Levels. Quotient of Item 5a and Item 8a. 5a. (1.0) 8a. $(0.685)=1.46$

Decay Constants for Potential Nuclides at the 115-F and 117-F Facilities

Nuclide Constant Nuclide Constant Nuclide Constant Nuclide Constant

$\begin{array}{llllllll}{ }^{3} \mathrm{H} & 5.6 \mathrm{E}-2 & 63 \mathrm{Ni} & 7.5 \mathrm{E}-3 & 135 \mathrm{CS} & 3.0 \mathrm{E}-7 & 237 \mathrm{~Np}+\mathrm{D} & 3.2 \mathrm{E}-7 \\ { }^{14} \mathrm{C} & 1.2 \mathrm{E}-4 & 90 \mathrm{Sr}+\mathrm{D} & 2.4 \mathrm{E}-2 & 137 \mathrm{CS}+\mathrm{D} & 2.3 \mathrm{E}-2 & 238 \mathrm{Pu} & 7.9 \mathrm{E}-3 \\ { }^{57} \mathrm{Co} & 9.3 \mathrm{E}-1 & 93 \mathrm{MO} & 2.3 \mathrm{E}-4 & 144 \mathrm{Ce} & 8.9 \mathrm{E}-1 & 239 \mathrm{Pu} & 2.8 \mathrm{E}-5 \\ { }^{60} \mathrm{Co} & 1.3 \mathrm{E}-1 & 99 \mathrm{TC} & 3.2 \mathrm{E}-6 & 152 \mathrm{Eu} & 5.0 \mathrm{E}-2 & 241 \mathrm{Am} & 1.6 \mathrm{E}-3 \\ { }^{55 \mathrm{Fe}} & 2.6 \mathrm{E}-1 & 124 \mathrm{Sb} & 4.2 \mathrm{E}+0 & 154 \mathrm{EU} & 8.9 \mathrm{E}-2 & & \\ { }^{59} \mathrm{Fe} & 5.6 \mathrm{E}+0 & 125 \mathrm{Sb}+\mathrm{D} & 2.5 \mathrm{E}-1 & 235 \mathrm{U}+\mathrm{D} & 9.8 \mathrm{E}-10 & & \\ { }^{59} \mathrm{Ni} & 8.7 \mathrm{E}-6 & 134 \mathrm{Cs} & 3.4 \mathrm{E}-1 & 238 \mathrm{U}+\mathrm{D} & 1.5 \mathrm{E}-10 & & \end{array}$

(a) The notation EXP $[-(a)(b)]$ means the exponential, $e^{-a b}$

FIGURE B.5. Allowable Residual Contamination Level Radioactive Decay Correction Worksheet - Example Problem 3 
1. Facility Name: Example Ploglem 3 - Correction for 300 rears of Radioactive Decay-

2. Prenarer's Name: W. E. Kennedy, Je.

3. Date Prepared: $6 / 30 / 83$

4. Determination of ARCL Dose Factors to Enter From Table 5.2.2. Check one Use Mode and one Contamination Condition.

\begin{tabular}{|c|c|c|c|c|}
\hline Use Mode/Contamination Condition & $\begin{array}{l}\text { Contam inated Surfaces } \\
\mathrm{Ci} / \mathrm{m}^{2} \text { or } \mathrm{dpm} / 100 \mathrm{~cm}^{2}\end{array}$ & $\begin{array}{c}\text { Surface Soil } \\
(\mathrm{DC} i / q) \\
\end{array}$ & $\checkmark \begin{array}{c}\text { Soft } 1-4 \mathrm{~m} \text { Deen } \\
(\mathrm{DC} i / \mathrm{g})\end{array}$ & $\begin{array}{c}\text { Soil } \geq 5 \mathrm{~m} \text { Meep } \\
(\mathrm{pC} i / \mathrm{q})\end{array}$ \\
\hline $\begin{array}{l}\text { Pestricted Use } 0.5 \mathrm{rem} / \mathrm{yr} \\
\text { Controlled Use } 00.5 \mathrm{rem} / \mathrm{yr} \\
\text { Unrestricted Use } 00.01 \mathrm{rem} / \mathrm{yr}\end{array}$ & $\begin{array}{l}\text { Col umn } 1 \\
\text { Column } 2 \\
\text { Column } 3\end{array}$ & $\begin{array}{l}\text { Column } 4 \\
\text { Column } 4 \\
\text { Column } 4 \\
\end{array}$ & $\begin{array}{l}\text { Column } 5 \\
\text { Column } 5 \\
\text { Column } 5\end{array}$ & $\begin{array}{l}\text { Column } 6 \\
\text { Column } 6 \\
\text { Column } 6\end{array}$ \\
\hline
\end{tabular}

Radionuclides 6. Radionuclide

6a. Radionuclide* 7. Scenario-Specific Considered

Concentrations

Concentrations ARCL Dose Factors

8. Product of

9. ARCL - Product

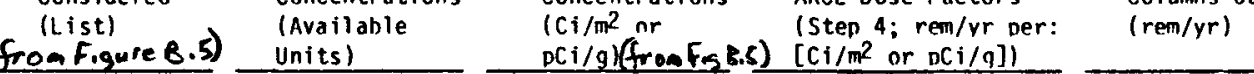
of Column 6a \&

10. Conversion Item $8 b$ to $\mathrm{dpm} / 100 \mathrm{~cm}^{2}$ (froa Figure B.5) Units)

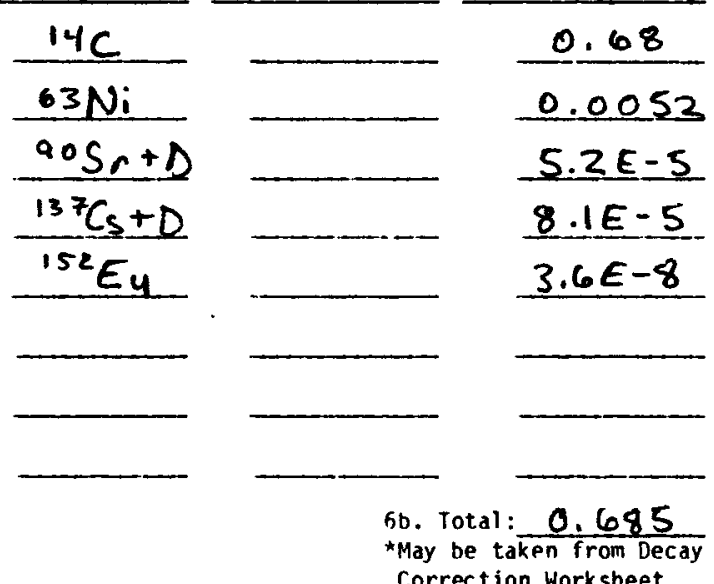

$\frac{\frac{8.3 E-8}{5.2 E-4}}{\frac{1.1 E-1}{2.7 E-3}} \frac{1}{5.0 E-3}$

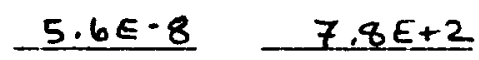
$2.7 E-6 \quad 6.0 E+0$ $5.7 E-6 \quad 6.0 E-2$ $2.2 E-7 \quad 9.3 E-2$ $1.8 E-10$ $4.2 E-5$ by $2.2 \times 10^{10}$ Correction Worksheet

8a. Total: $8.68 E-6$ 9a. Total: 786 10a. Total 8b. Annual Dose Limit 9b. Check: Divided by $8 \mathrm{a}$. $9 \mathrm{9}$. Divided by $6 \mathrm{~b}$. $\left.=10.50 .01 \frac{8.6860}{=80}=\frac{(786}{1150} \div 0.685\right)$

$$
=1150 \frac{80}{=80}=\frac{786}{1150} \frac{0.685}{=80} \text { ? }
$$

11. Present Gross Contamination Level Yielding Future ARCL of Item 9a: (Used only with Decay Correction Worksheet) Product of I tem $9 \mathrm{a}$ (or $10 \mathrm{a}$ ) and I tem 9 of Decay Correction Worksheet.

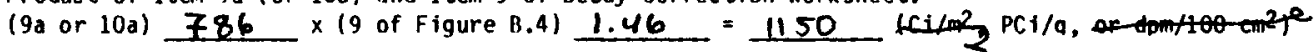

12. Additional Notes.

FIGURE B.6. Allowable Residual Contamination Level Worksheet for Facilities at the Hanford Site - Example Problem 3 


\section{Facility Name:}

2. Preparer's Name:

3. Date:

4. Radi onuc 1 ides Considered

5. ARCL ( $\mathrm{dpm} / 100 \mathrm{~cm}^{2}$

(List)

or $\mathrm{pCi} / \mathrm{g})$
6. Alpha, Beta or 7. Intensity Ciamma Energies (Fraction)
(MeV)

8. Detector Efficiency

(Fraction or

9. Sampling Efficiency

10. Instrument

$d p m / p(i / q)$

(Fraction) Response (I tems

$\longrightarrow$

-

$-$

!r

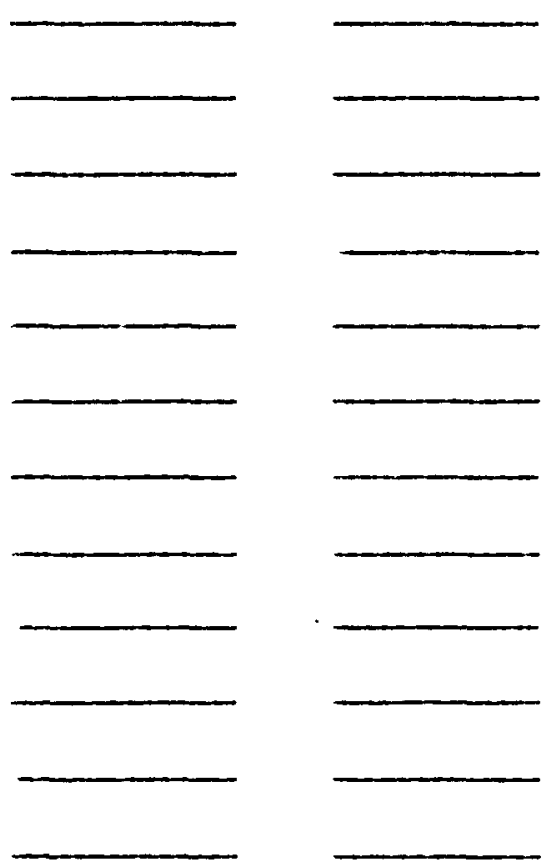

5a. Total
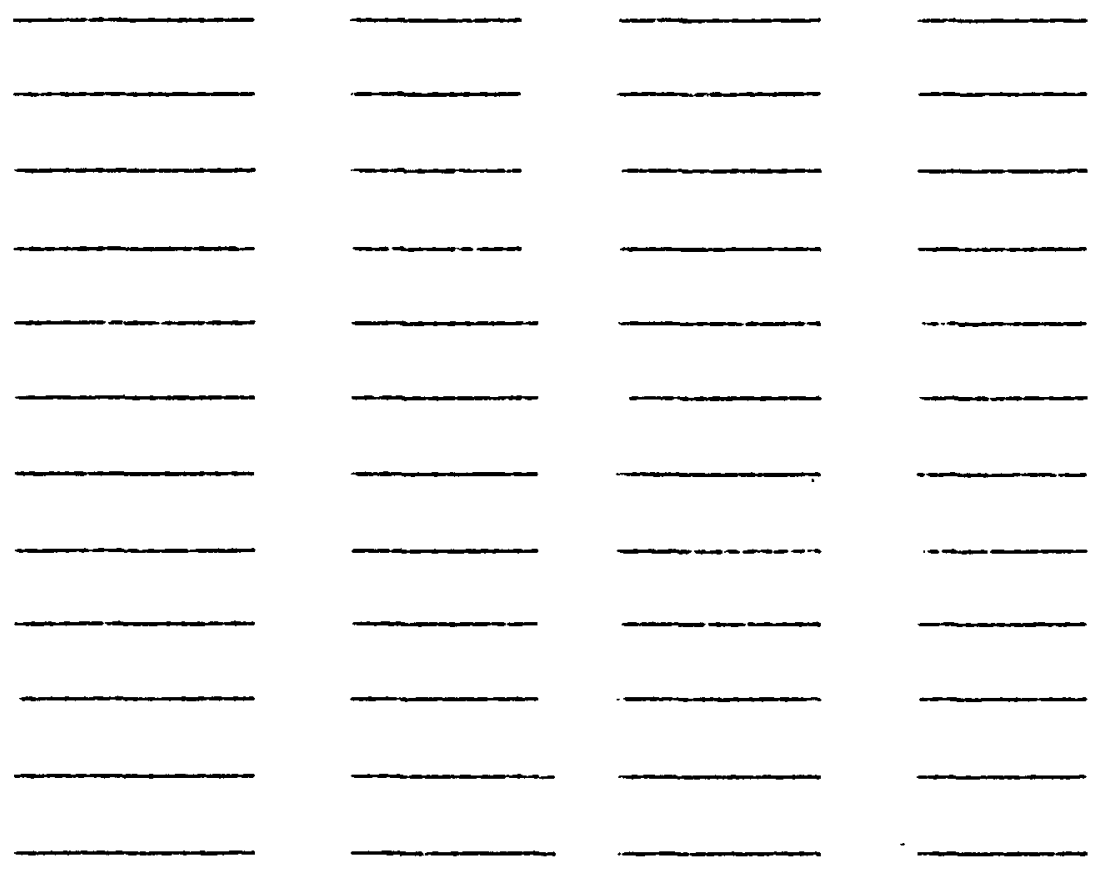

$5 \times 7 \times 8 \times 9)$ (counts/minute)

10a. Total

FIGURE B.7. Instrument Response Worksheet 
3. Date. Enter the date on which the worksheet was completed.

4. Radionuclides Considered. Enter the radionuclides considered in the space provided. If additional space is required, use additional worksheets.

5. ARCL. Enter the ARCL values for each radionuclide in the mixture and enter the total in Item 5a. Note: These values are obtained from Items 9 or 10 of the ARCL Work sheet (Figure B.1).

6. Alpha, Beta, or Gamma Energies. Enter the al pha, beta, or gamma energies (in MeV) per disintegration for each radionuclide. Note: Identify the type of particle or photon for each energy.

7. Intensity. Enter the intensity of each alpha, beta, or gamma energy per disintegration for each radionuclide. Note: This should be a fraction $\leq 1.0$.

8. Detector Efficiency. Enter the detector efficiency for each type of particle or photon for each radionuclide. Note: This should be a fraction $\leq 1.0$.

9. Sampling Efficiency. Enter the sampling efficiency for the procedure used. Note: For smear samples of removable surface contamination, this fraction will be <1.0, while for in situ measurements or soil samples, it will equal 1.0 .

10. Instrument Response. The instrument response for each alpha, beta, or gamma is determined by multiplying the values shown in Items $5,7,8$ and 9. The total instrument response for the mixture is the sum of the values shown and is reported in Item 10a.

The successful completion of this worksheet relies upon the development of an instrument calibration curve for each type of particle or photon over a range of decay energies. As an example of the use of this worksheet, the beta energy calibration curve (developed in a previous study for a smear-sample detection system) is assumed (Kennedy et a1. 1981). The detection system consists of an Eberline Model No. MS-2 miniscaler with a 
beta-type scintillation crystal. This system is semiportable and can be used onsite for smear-sample analysis. The energy calibration curve was developed using ${ }^{14} \mathrm{C},{ }^{99} \mathrm{TC},{ }^{36} \mathrm{Cl}, 210 \mathrm{Bi}$, and $234 \mathrm{~Pa}$ sources of known strength. The resulting calibration curve (Figure B.8) shows counting efficiency $(\%)$ versus energy for beta emitters. The efficiencies range from $10 \%$ for $14 \mathrm{C}$ to about $45 \%$ for $36 \mathrm{Cl}$. The mixture of beta emitters considered in the first example problem is used to demonstrate the use of this worksheet. This mixture consists of $14 \mathrm{C}(70 \%), 36 \mathrm{Ni}(5 \%), 90 \mathrm{Sr}+\mathrm{D}$ $(7 \%), 137 \mathrm{CS}+\mathrm{D}(8 \%)$, and $152 \mathrm{Eu}(10 \%)$. The resulting ARCL, for removable surface contamination, is reported as $2200 \mathrm{dpm} / 100 \mathrm{~cm}^{2}$ (see Figure B.2). These radionuclides, their contribution to the total ARCL (from Figure B.2), their beta energies, and their beta intensities are entered in the worksheet (Figure B.9). For this example, the smear samples are assumed to remove $10 \%$ of the surface contamination, thus 0.1 is entered for

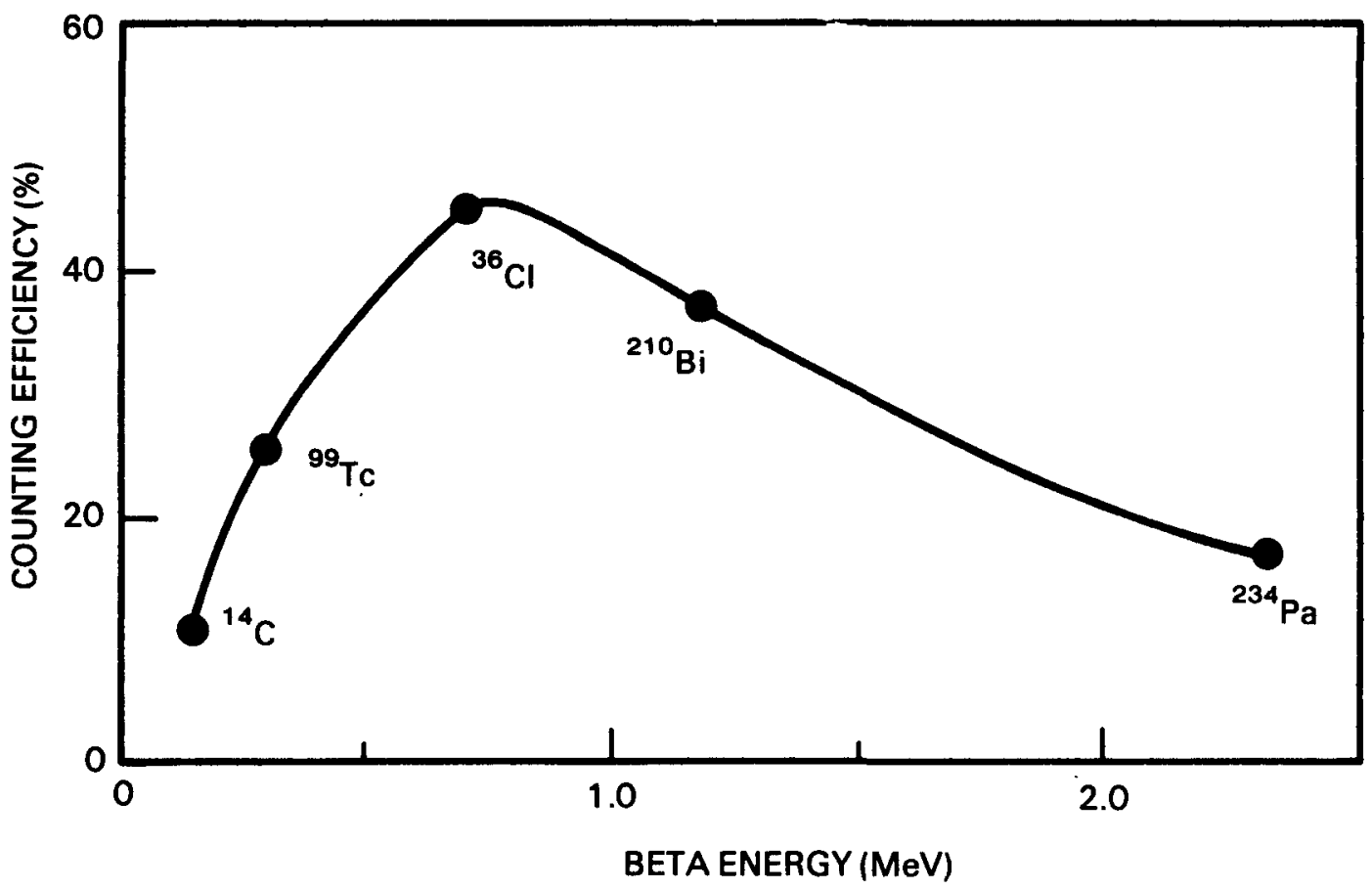

FIGURE B.8. Calibration Curve for the Eberline MS-2 Miniscaler and Beta-Type Scintillation Probe 
1. Facility Name: Emmple Proscem 4 - Unrestricted Release of a Facility

2. Preparer's Name: W.E.Kensady, JR.

3. Date: $6 / 30 / 83$

4. Radionuclides 5. ARCL Considered (List)

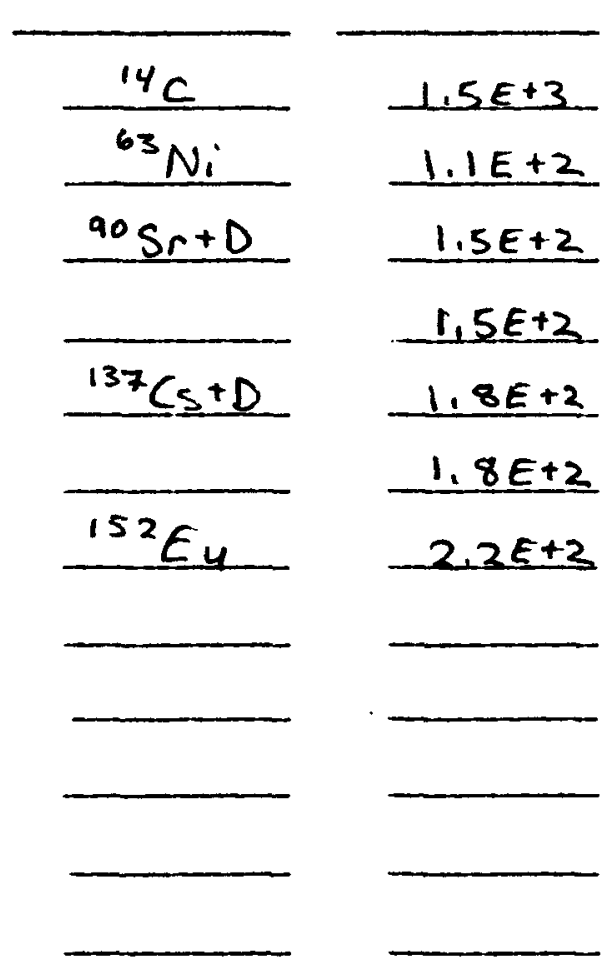

5a. Total $2,2 E+3$
6. Alpha, Reta or fiamma Energies $(\mathrm{MeV})$
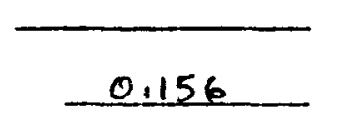

0.066

0.546

2.2

0.51

1.20

0.687

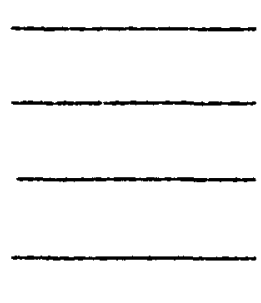

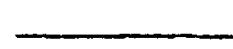

7. Intensity (Fraction)

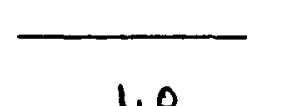

1,0

1.0

1.0

$-1.2$

0.95

0.05

0.71
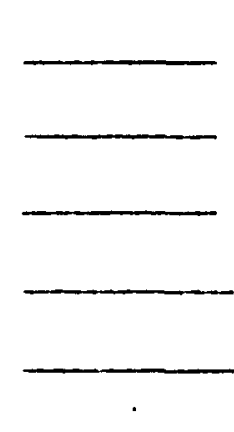
9. Sampling Efficiency (Fraction) Efficioncy (Fraction or $\mathrm{Anm} / \mathrm{nCi} / \mathrm{q})$ 0.10
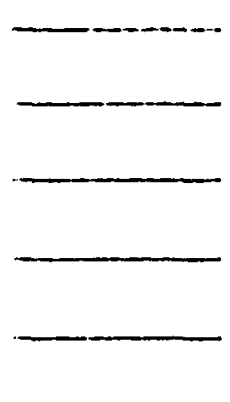

10. Instrument Response (I tems $5 \times 7 \times 8 \times 9)$

(counts/minute)
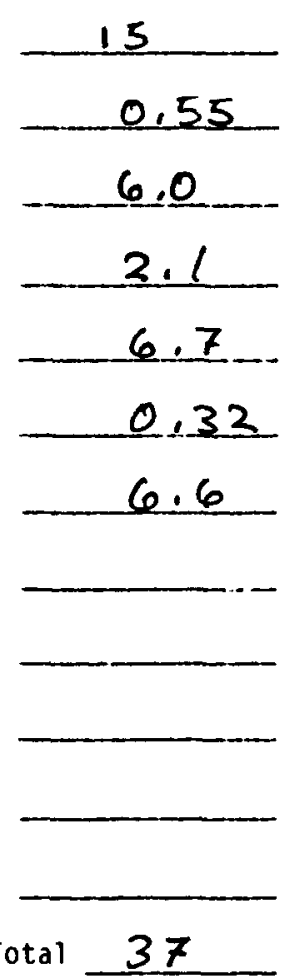

FIGURE B.9. Instrument Response Worksheet - Example Problem 4 
each radionuclide and beta in Item 9 . The product of Items 5 through 9 is entered in Item 10 for each beta, with the total detector response shown in Item 10a.

The resulting instrument response is 37 counts per minute above background. The overall detection efficiency for this instrument and procedure is $(37 / 2200)$, or about $1.7 \%$. It should be noted that this instrument is not a "standard" instrument used for field surveys at the Hanford Site. A similar calibration on procedure should be conducted to determine the instrument response for the pancake GM probe. Two major differences are apparent with the use of the pancake GM probe instead of the Eberline beta-type scintillation system. First, the GM probe is less sensitive, thus the calibration curve would show a lower percent detection at all energies. Second, the probe would record count rates directly from surfaces, thus an estimate of the fraction of the contamination transferred to a smear is not required. 
No. of

Copies

OFFSITE

27 DOE Technical Information Center

ONSITE

DOE Richland Operations Office

H. E. Ransom

150 UNC Nuclear Industries

R. A. Winship (150)

100 Pacific Northwest Laboratory

J. B. Brown, Jr. (2)

T. D. Chikalla

D. H. Denham

T. H. Essig

L. G. Faust

W. A. Glass

W. E. Kennedy, Jr. (50)

J. M. Latkovich

W. D. McCormack

B. A. Napier (20)

I. C. Nelson

A. M. Platt

W. D. Richmond

J. V. Robinson

R. G. Schreckhise (2)

J. M. Selby

R. I. Smith

J. K. Soldat (2)

S. L. Stein

C. M. Unruh

E. C. Watson (2)

Publishing Coordination (2)

Technical Information (5) 